\title{
Overview of Water Resources in and Near Indian Lands in Northeastern Kansas and Southeastern Nebraska
}

By T.J. TROMBLEY, R.J. WOLF, P.R. JORDAN, and L.D. BREWER

\section{U.S. GEOLOGICAL SURVEY}

Water-Resources Investigations Report 96-4070

Prepared in cooperation with the IOWA TRIBE OF KANSAS AND NEBRASKA, the KICKAPOO TRIBE OF KANSAS, the PRAIRIE BAND OF POTAWATOMI, the SAC AND FOX TRIBE OF MISSOURI, and the BUREAU OF INDIAN AFFAIRS

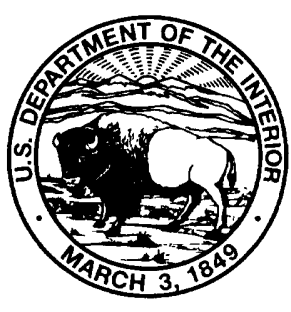




\section{U.S. DEPARTMENT OF THE INTERIOR \\ BRUCE BABBITT, Secretary}

U.S. GEOLOGICAL SURVEY

Gordon P. Eaton, Director

For additional information write to:

Copies of this report can be purchased from:

District Chief

U.S. Geological Survey

4821 Quail Crest Place

Lawrence, Kansas 66049-3839
U.S. Geological Survey

Branch of Information Services

Box 25286

Denver, CO 80225-0286 


\section{CONTENTS}

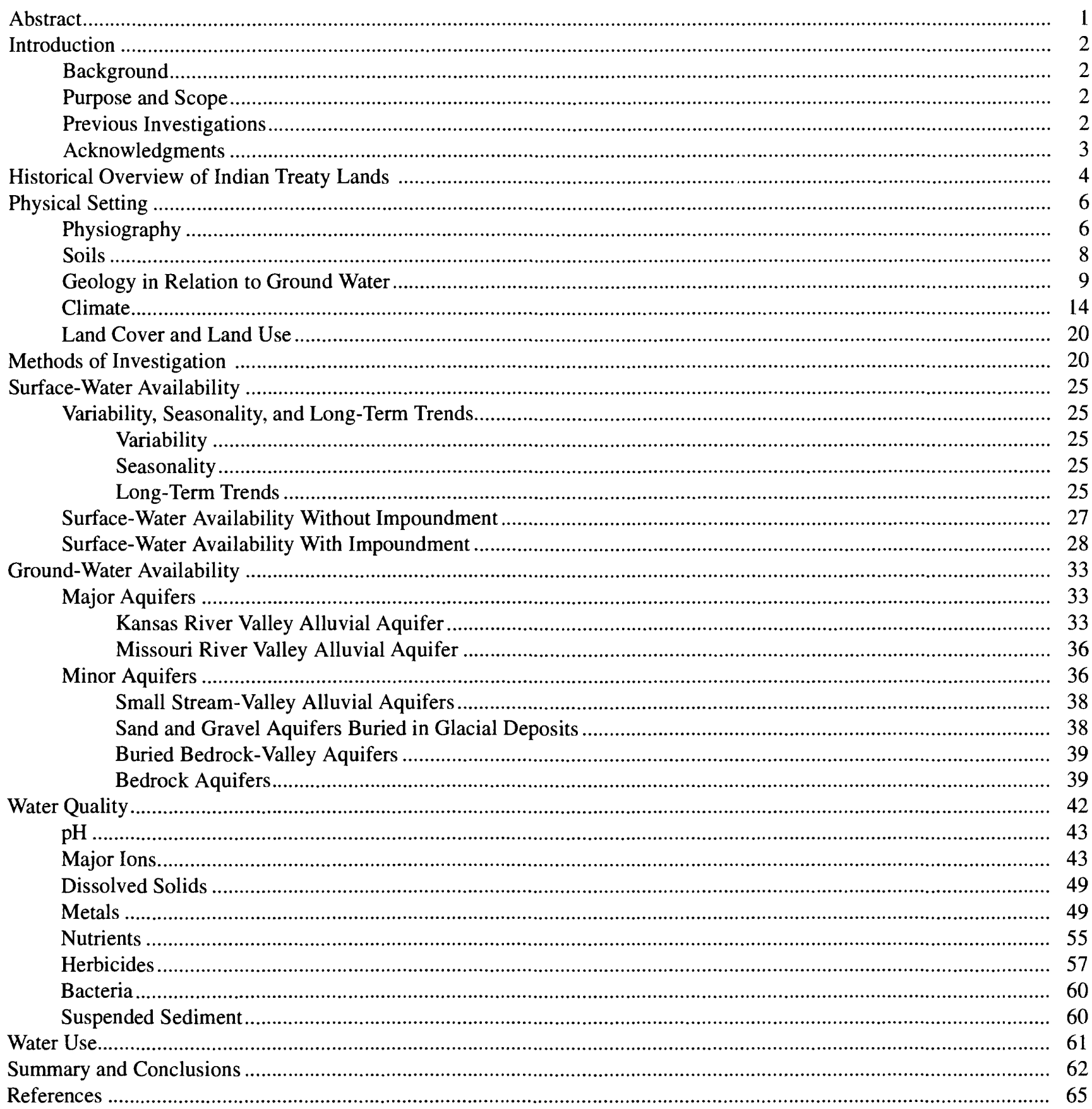

\section{FIGURES}

1-4. Maps showing:

1. Location of study area, extent of Iowa, Kickapoo, Potawatomi, and Sac and Fox treaty lands, and hydrologic unit boundaries in northeastern Kansas and southeastern Nebraska 


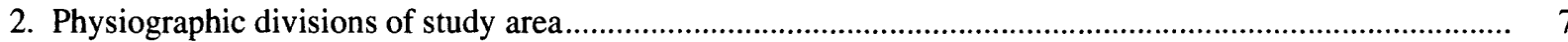

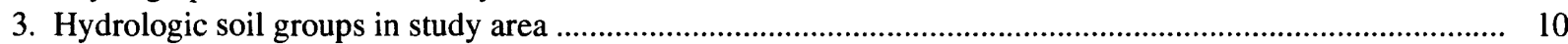

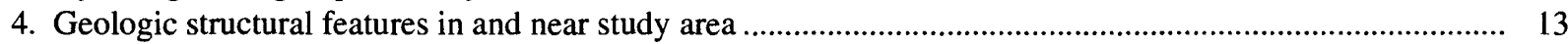

5. East-west geohydrologic section across study area ..................................................................................... 14

6. Map showing altitude and configuration of top of Precambrian rocks in study area ........................................ 15

7. Map showing upper Paleozoic rocks and Cenozoic deposits present at the surface of the study area.................. 18

8-10. Graphs showing:

8. Average monthly precipitation for Horton, Kansas, 1888-1991, and average annual precipitation and 22-year moving average precipitation for Leavenworth, Kansas, 1836-1994

9. Monthly mean maximum, mean, and mean minimum temperatures for Horton, Kansas, 1888-1991 ........... 21

10. Relation of mean summer precipitation to mean summer temperatures in the Northeast Kansas

Climatic Region

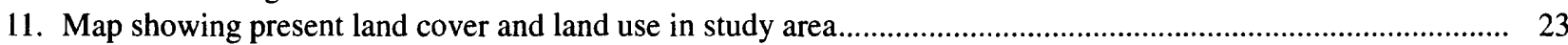

12. Diagram showing local well-numbering system used in this report ............................................................. 24

13. Map showing comparative magnitude of mean annual streamflows in and near study area and location of streamflow-gaging stations referred to in this report.

14-16. Graphs showing:

14. Seasonal distribution of 7-day low flows and monthly mean streamflows for Soldier Creek near Topeka, Kansas, 1930-32 and 1936-92

15. Annual mean streamflow and 15 -year moving average streamflow for Soldier Creek near Topeka, Kansas, 1936-92

16. Draft-storage curves for 2-percent chance of draft-rate deficiency in study area (1)

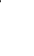
8

7. Map showing altitude and configuration of water table in Kansas River Valley alluvial aquifer, spring 1967 , and location of wells referred to in this report.

18. Hydrograph showing water levels in well completed in the Kansas River Valley alluvial aquifer near Topeka, Kansas, 1950-91

19. Map showing altitude and configuration of water table in Missouri River Valley alluvial aquifer, 1967 and January 1968

20. Hydrograph showing water levels in well completed in small stream-valley alluvial aquifer in Jackson County, Kansas, 1948-70

21. Hydrograph showing water levels in well completed in a sand and gravel aquifer buried in glacial deposits in Jackson County, Kansas, 1972-93

22. Map showing location of preglacial valleys in study area...

23. Hydrograph showing water levels in well completed in a buried bedrock-valley aquifer in Nemaha County, Kansas, 1984-94

24. Hydrograph showing water levels in well completed in an unconfined aquifer of Pennsylvanian-age limestone in Brown County, Kansas, 1960-68

25-36. Boxplots showing distribution of:

25. $\mathrm{pH}$ values in surface water and ground water of study area

26. Calcium concentrations in surface water and ground water of study area.......

27. Magnesium concentrations in surface water and ground water of study area

28. Sodium concentrations in surface water and ground water of study area...........

29. Potassium concentrations in surface water and ground water of study area..

30. Bicarbonate concentrations in surface water and ground water of study area

31. Chloride concentrations in surface water and ground water of study area .

32. Sulfate concentrations in surface water and ground water of study area.

33. Dissolved-solids concentrations in surface water and ground water of study area...

34. Total iron concentrations in surface water and ground water of study area...

35. Total manganese concentrations in surface water of study area

36. Nitrite plus nitrate concentrations in surface water from selected surface-water-quality sampling sites in

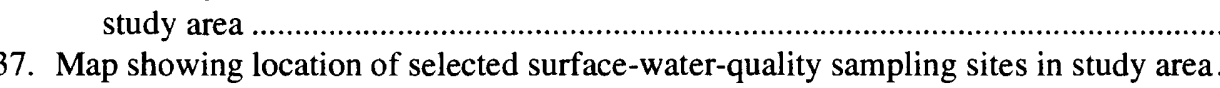




\section{FIGURES-Continued}

38. Boxplots showing distribution of phosphorus concentrations in surface water from selected surface-waterquality sampling sites in study area

39. Graphs showing water use in 1990 by drainage basin.

\section{TABLES}

1. Hydrologic characteristics of soils in the study area ............................................................................. 11

2. Geohydrologic systems and associated water-bearing characteristics in and near the study area ..................... 16

3. Magnitude and frequency of low flows at selected streamflow-gaging stations in and near the study area ........... 29

4. Selected surface-water-quality sampling sites referred to in this study ....................................................... 


$\begin{array}{rcl}\text { Multiply } & \text { By } & \text { To obtain } \\ \text { acre } & 4,047 & \text { square meter } \\ \text { acre } & 0.4047 & \text { square hectometer } \\ \text { acre-foot }(\mathrm{acre}-\mathrm{ft}) & 1,233 & \text { cubic meter } \\ \text { cubic meter per square kilometer } \\ \text { acre-foot per square mile }\left(\mathrm{acre}-\mathrm{ft} / \mathrm{mi}^{2}\right) & 476.1 & \text { cubic meter per second } \\ \text { cubic foot per second }\left(\mathrm{ft}^{3} / \mathrm{s}\right) & 0.02832 & \text { cubic meter per second per } \\ \text { cubic foot per second per square } & 0.01093 & \text { square kilometer } \\ \text { mile }\left[\left(\mathrm{ft}^{3} / \mathrm{s}\right) / \mathrm{mi}^{2}\right] & & \text { degree Celsius }\left({ }^{\circ} \mathrm{C}\right) \\ \text { degree Fahrenheit }\left({ }^{\circ} \mathrm{F}\right) & { }^{\circ} \mathrm{C}=\left({ }^{\circ} \mathrm{F}-32\right) / 1.8 & \text { meter } \\ \text { foot }(\mathrm{ft}) & 0.3048 & \text { meter per year } \\ \text { foot per year }(\mathrm{ft} / \mathrm{yr}) & 0.3048 & \text { meter squared per day } \\ \text { gallon } & 0.09290 & \text { liter } \\ \text { foot squared per day }\left(\mathrm{ft}{ }^{2} / \mathrm{d}\right) & 3.785 & \text { liter per second } \\ \text { gallon per minute }\left(\mathrm{gal} / \mathrm{min}^{2}\right) & 0.06309 & \text { millimeter } \\ \text { inch }(\mathrm{in} .) & 25.4 & \text { kilometer } \\ \mathrm{mile}(\mathrm{mi}) & 1.609 & \text { cubic meter per second } \\ \text { million gallons per day }(\mathrm{Mgal} / \mathrm{d}) & 0.04381 & \text { square kilometer } \\ \text { square mile }\left(\mathrm{mi}{ }^{2}\right) & 2.590 & \end{array}$

${ }^{1}$ The standard unit for transmissivity $(\mathrm{T})$ is cubic foot per day per square foot times foot of aquifer thickness or $\left[\left(\mathrm{ft}^{3} / \mathrm{d}\right) / \mathrm{ft}^{2}\right] \mathrm{ft}$. This mathematical expression reduces to foot squared per day $\left(\mathrm{ft}^{2} / \mathrm{d}\right)$, which is used in this report.

\section{Abbreviations}

colonies per 100 milliliters

Health Advisory Level

$\mathrm{col} / 100 \mathrm{~mL}$

Maximum Contaminant Level

HAL

microgram per liter

MCL

milligram per liter

$\mu \mathrm{g} / \mathrm{L}$

Secondary Maximum Contaminant Level

$\mathrm{mg} / \mathrm{L}$

U.S. Environmental Protection Agency

SMCL

USEPA

\section{Vertical Datum}

Sea level: In this report, "sea level" refers to the National Geodetic Vertical Datum of 1929_a geodetic datum derived from a general adjustment of the first-order level nets of the United States and Canada, formerly called Sea Level Datum of 1929. 


\title{
Overview of Water Resources in and Near Indian Lands in Northeastern Kansas and Southeastern Nebraska
}

\author{
By T.J. Trombley, R.J. Wolf, P.R. Jordan, and L.D. Brewer
}

\section{Abstract}

An overview of water resources is provided for a 4,005-square-mile area of northeastern Kansas and southeastern Nebraska that includes the treaty lands for the Iowa Tribe of Kansas and Nebraska, the Kickapoo Tribe of Kansas, the Prairie Band of Potawatomi, and the Sac and Fox Tribe of Missouri.

The only plentiful supplies of surface water are available from the Missouri and Kansas Rivers. The smallest mean streamflows for 4 consecutive months occur in November through February for most streams in the area. The smallest flows for 7 consecutive days in a year occur most often in August, September, or October.

The typical seasonal distribution of streamflows indicates a pattern favorable for the sameyear use of small surface-water impoundments for low-flow augmentation; large flows that could be impounded typically occur in the month shortly before augmentation is most needed. However, droughts of 2 or more consecutive years are common and would largely negate the advantage of using small impoundments except for very small water-supply needs.

Alluvial deposits along the Kansas and Missouri Rivers provide the largest well yields in the study area, but these deposits are limited in areal extent. The Kansas River alluvium reaches a maximum saturated thickness of about 70 feet, and the Missouri River alluvium reaches a maximum thickness of 120 feet. Well yields in the Kansas River generally range from 300 to 1,000 gallons per minute (gal/min) but may be as large as
2,500 gal/min. Well yields in the Missouri River alluvium generally range from 150 to $2,500 \mathrm{gal} / \mathrm{min}$ but may be as large as $3,000 \mathrm{gal} / \mathrm{min}$. Although generally capable only of small sustained yields to wells, minor aquifers are important because they are available throughout most of the study area. Within the thick, mostly fine-grained glacial deposits, isolated sand and gravel layers may yield adequate supplies for stock-watering or domestic use.

Sodium concentrations exceed the U.S. Environmental Protection Agency's (USEPA) Secondary Maximum Contaminant Level of 20 milligrams per liter most often in the middle Kansas and Delaware Basins. Total iron and manganese concentrations in water generally exceed the USEPA Secondary Maximum Contaminant Levels of 50 micrograms per liter for iron and 300 micrograms per liter for manganese. Atrazine concentrations in surface water, primarily from post-application runoff, commonly exceed the USEPA Maximum Contaminant Level of 3.0 micrograms per liter during the months of May, June, and July. Most of the erosion and about onehalf of the total sediment yield in parts of the study area may result from sheet and rill erosion and gullying on cultivated cropland.

A total of 3.13 million gallons per day (Mgal/d) of water was used in 1990 in the Big Nemaha River Basin, 74 percent of which was derived from ground water. In the Wolf River Basin, $1.29 \mathrm{Mgal} / \mathrm{d}$ were used, 71 percent derived from ground water. The Middle Kansas River Basin had the highest water use, $83.01 \mathrm{Mgal} / \mathrm{d}$, 67 percent of which was from surface water. A 
total of $4.37 \mathrm{Mgal} / \mathrm{d}$ was used in the Delaware River Basin, 55 percent from ground water.

\section{INTRODUCTION}

\section{Background}

Increasing demand for and degradation of water supplies has increased concern about water-resources issues during the past few years. As a result, the Iowa Tribe of Kansas and Nebraska, the Kickapoo Tribe of Kansas, the Prairie Band of Potawatomi, and the Sac and Fox Tribe of Missouri are interested in prudent development of the water resources in and near their respective treaty lands. The Tribes would like their interests included in the State Water Plan developed by the Kansas Legislature. Therefore, in 1988, the U.S. Geological Survey (USGS), in cooperation with the four tribes and the Bureau of Indian Affairs (BIA), began a reconnaissance study to provide an overview of the availability and quality of water resources in and near Indian treaty lands in northeastern Kansas and southeastern Nebraska.

The study-area boundaries (fig. 1), with the exception of the northern boundary (a township line), are hydrologic and include the treaty lands for the four tribes. For presentation purposes, the $4,005-\mathrm{mi}^{2}$ study area is divided into four major drainage basins on the basis of standardized USGS hydrologic units (Seaber and others, 1987). The Big Nemaha River Basin (hydrologic unit 10240008) drains the Iowa and Sac and Fox Reservations. The Wolf River Basin (hydrologic unit 10240005) drains part of the Iowa and Kickapoo Reservations within the 1854 treaty boundary. The middle Kansas River Basin (hydrologic unit 10270102) drains most of the Potawatomi Reservation. Finally, the Delaware River Basin (hydrologic unit 10270103) drains the northeast corner of the Potawatomi Reservation and most of the Kickapoo Reservation.

\section{Purpose and Scope}

This report presents the results of an overview of water resources in and near Indian lands in northeastern Kansas and southeastern Nebraska and is intended as comprehensive background information for those readers who may be interested in pursuing inclusion of
Indian treaty lands in the Kansas State Water Plan. The primary objective of the overview was to describe surface- and ground-water availability, water quality, and water use in the study area. These objectives were accomplished by: (1) compilation and analysis of available water data (Brewer and others, 1994); (2) presentation of maps of physical and hydrologic features in the study area, such as geology, soils, land use, surface drainage, aquifer boundaries, and location of recent (1990) water appropriations using geographic information system (GIS) technology; (3) generation of maps using GIS technology to group water data for comparison and analysis; (4) definition of flow and water quality in streams; and (5) definition of water availability and quality in aquifers. The study did not include the collection of any new water-resources data.

\section{Previous Investigations}

Many studies relating to water resources in the study area have been completed. In a study of the water resources of the 1862 Kickapoo treaty lands, Van Doren-Hazard-Stallings (1981) indicate that (1) water suppliers in the area surrounding the reservation experience supply shortages or have problems with the quality of raw water; (2) economic development on the reservation has been slow due in part to insufficiently developed water resources; and (3) there is a potential for the construction of five surface-water impoundments on the reservation with a total storage capacity of 4,500 acre-ft.

In studies of the Kansas River and its associated alluvium, Beck (1959) described the geology and ground-water resources of the Kansas River between Wamego and Topeka, Kansas. Fader (1974) described ground-water availability in the Kansas River Valley from Junction City to Kansas City, Kansas. Winslow and Nuzman (1966) described ground-water availability in the Topeka area for 1950. Wolf and Helgesen (1993) used a finite-element computer model to simulate hypothetical flows and water levels in the Kansas River Valley from Wamego to Topeka for 8-year periods of below-average, near-average, and aboveaverage streamflow and precipitation, with various hypothetical pumpage options.

In the Missouri River Basin, Emmett and Jeffery (1969) completed a ground-water reconnaissance of the Missouri River alluvium between Kansas City, Missouri, and the Iowa border. Hedman and Jorgensen 


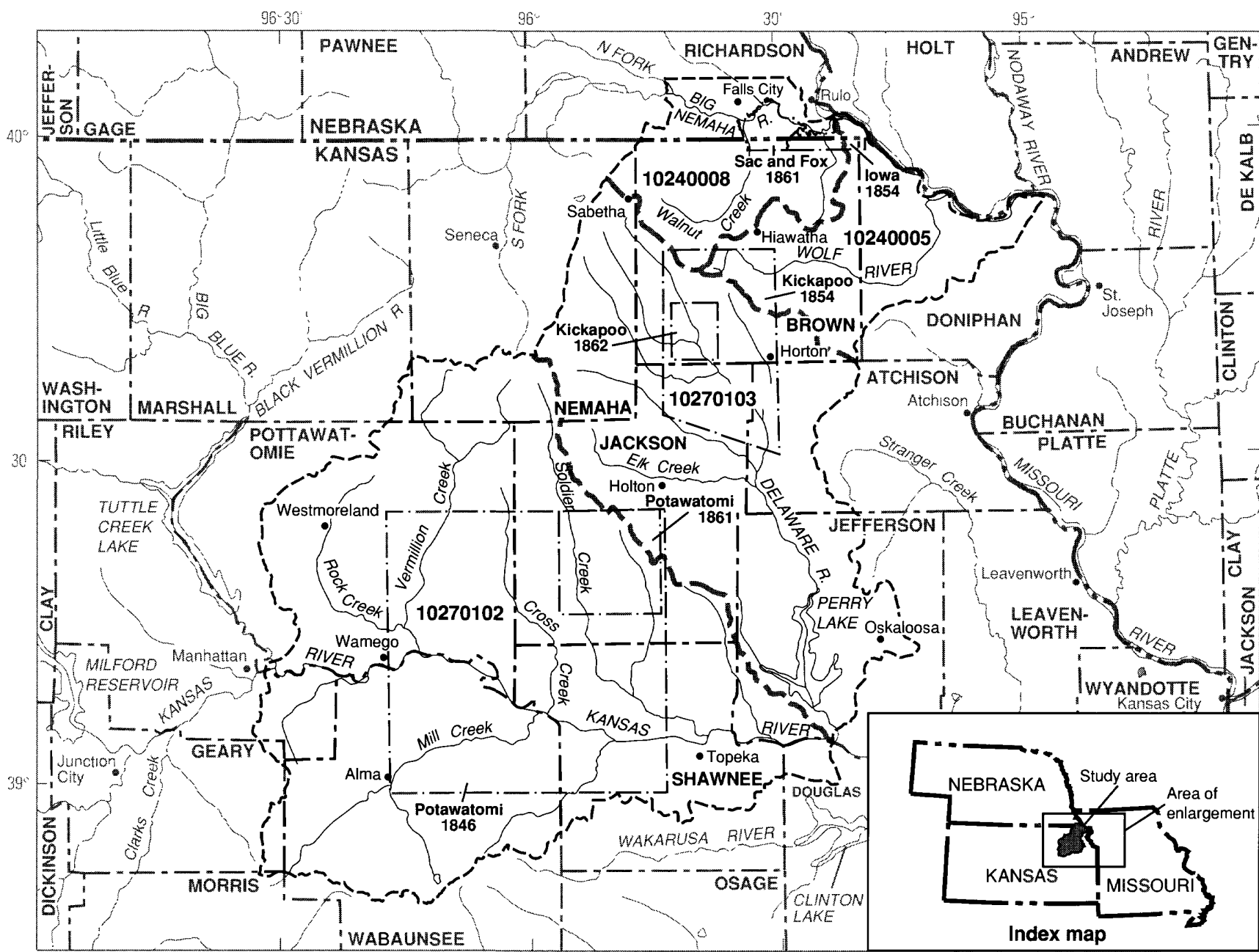

Base from U.S. Geological Survey digital data, 1:100,000, 1972 Lambert Conformal Conic projection Standard parallels $33^{\circ}$ and $45^{\circ}$

\section{EXPLANATION}

30 MILES

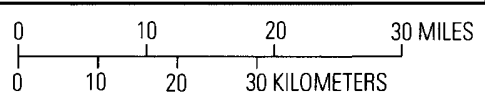

10270102 Hydrologic unit boundary and number-Number is hydrologic unit code from Seaber and others (1987)

--ー--- Boundary of study area

- - - - - Boundary of Indian treaty lands - Boundaries are from U.S. Geological Survey 71/2-minute topographic quadrangles

Figure 1. Location of study area, extent of lowa, Kickapoo, Potawatomi, and Sac and Fox treaty lands, and hydrologic unit boundaries in northeastern Kansas and southeastern Nebraska.

(1990) evaluated the interaction of surface and ground water in the Missouri River alluvium.

Jane Denne and others (Kansas Geological Survey, written commun., 1991) evaluated the hydrology and geochemistry of glacial deposits in northeastern Kansas. A number of geohydrology and groundwater resources reports were completed for counties in the study area including Atchison (Frey, 1941; Ward, 1973), Brown (Bayne and Schoewe, 1967), Doniphan (Bayne, 1973), Douglas (O'Connor, 1960), Jackson
(Walters, 1953), Jefferson (Winslow, 1972), Nemaha (Ward, 1974), and Shawnee (Johnson and others, 1967 ) in Kansas, and Richardson County (Emery, 1964) in Nebraska.

\section{Acknowledgments}

The authors express their appreciation to Robert Delk, BIA, Billings, Montana; P.J. Workman, 
John Baggs, and Michael Reed, BIA, Anadarko, Oklahoma; the Horton Agency, BIA, Horton, Kansas; and to the four Kansas tribes-the Iowa Tribe of Kansas and Nebraska, the Kickapoo Tribe of Kansas, the Prairie Band of Potawatomi, and the Sac and Fox Tribe of Missouri for their assistance and guidance in this study.

\section{HISTORICAL OVERVIEW OF INDIAN TREATY LANDS}

An understanding of the historical presence and distribution of the various tribes in Kansas, prior to and after the European settlement, may have an effect on the various tribes' water-rights claims. Before 1840 , Kansas was home to many native, nomadic, and emigrant Indian tribes. Today (1996), the Iowa Tribe of Kansas and Nebraska (Iowa), the Kickapoo Tribe of Kansas (Kickapoo), the Prairie Band of Potawatomi (Potawatomi), and the Sac and Fox Tribe of Missouri (Sac and Fox) are the only tribes that have treaty lands in Kansas. These four Indian tribes originally were from areas around the Great Lakes and were relocated to Kansas by pressure of non-native settlement.

The native Indian tribes of Kansas, prior to 1825 , included the village builders-the Kansas, Osage, Pawnee, and Wichita. The nomadic Indian tribes who hunted in Kansas were the Arapaho, Cheyenne, Commanche, and Kiowa. The emigrant Indian tribes associated with the early history of Kansas included the Cayuga, Cherokee, Chippewa, Delaware, Fox, Iowa, Kaskaskia, Kickapoo, Miami, Munsee, Oneida, Onondaga, Ottawa, Peoria, Piankanshaw, Potawatomi, Quapaw, Sac, Seneca, Shawnee, Stockbridge, Wea, and Wyandotte. All of these tribes with the exception of the Iowa, Kickapoo, Potawatomi, and Sac and Fox subsequently were removed from Kansas (Brenda Shadwick, Bureau of Indian Affairs, written commun., 1991).

The Iowa Tribe originally came from the present states of lowa, Minnesota, and Missouri (Brenda Shadwick, Bureau of Indian Affairs, written commun., 1991), where several rivers including the Des Moines, Cedar, and Iowa and numerous lakes and smaller streams provided water supplies and transportation. Treaties signed August 4, 1824, August 19, 1825 , July 15,1830 , and November 23,1837 , ceded land claims in Iowa, Minnesota, and Missouri. A reservation in northeastern Kansas was assigned to the Iowa Tribe by a treaty in September 17, 1836. The Iowa
Reservation was located along the Great Nemaha River in present Brown County, Kansas, and Richardson County, Nebraska; but this reservation was reduced by the treaty of May 17,1854 . The reservation was again reduced by a treaty signed on March 6 , 1861 , which provided for the cession of certain Iowa tribal land in Kansas to the United States for the Sac and Fox Tribe (Blaine, 1979, p. 272). After an agreement in 1890, a part of the Iowa Tribe moved to central Oklahoma for land that was allotted to them in severalty, the surplus lands being opened to settlement (Brenda Shadwick, Bureau of Indian Affairs, written commun., 1991).

Today, the lowa Reservation borders the Sac and Fox Reservation on the east in Brown County, Kansas, and Richardson County, Nebraska (fig. 1). There are 416 acres of allotted land and 1,026 acres of tribal land within the Iowa Reservation (Brenda Shadwick, Bureau of Indian Affairs, written commun., 1991). The allotted land resulted from the passing of the General Allotment Act in 1887, which is discussed at the end of this section. Tribal land is land owned by the tribe.

About 1667, the Kickapoo Tribe was located between the Fox and Wisconsin Rivers in southern Wisconsin. A few years later they moved to the Sangamon River in central Illinois, then to the Vermillion River in eastern Illinois, and along the Wabash River in western Indiana (Brenda Shadwick, Bureau of Indian Affairs, written commun., 1991).

The Treaty of Fort Wayne on September 30, 1809, and at Fort Harrison on August 30, 1819, ceded the Kickapoo lands in Illinois for lands near the Osage River in Missouri. In July 1820, an amendment to the 1819 treaty called for a reservation in northeast Kansas instead of the lands in Missouri. However, not until another treaty was signed on October 24,1832 , did the relocation seriously get underway. The new reservation in northeast Kansas was in the present counties of Atchison, Brown, and Jackson.

The lands beyond the Missouri River including Kansas once were considered part of the "Great American Desert." When migration to Santa Fe, New Mexico, and Oregon increased settlements west of the Rocky Mountains, lands in Kansas became more familiar to the non-native American settlers. Once immigrating settlers realized that the lands were fertile, they wanted the lands opened for settlement. The Commissioner of Indian Affairs then negotiated treaties with the Kickapoo resulting in a reduction of their 
lands in 1854 and a further reduction in 1862 (Herring, 1988 , p. 129). Today, the Kickapoo Reservation is situated in southwestern Brown County, Kansas, far from any large stream (fig. 1). It consists of 3,154 acres of allotted land and 4,000 acres of tribal land (Brenda Shadwick, Bureau of Indian Affairs, written commun., 1991).

The Potawatomi Tribe originally was one tribe with the Chippewa and the Ottawa. By the time of the first recorded European contact (with a French explorer in 1634), the Potawatomi were roaming the Great Lakes area. In the late 17 th or early 18 th century, the Potawatomi, Chippewa, and Ottawa traveled west to Lake Huron in search of new hunting grounds. At Mackinac Straits the tribe divided, and the Potawatomi migrated into Michigan's lower peninsula. The Iroquois with their guns pushed the Potawatomi from Michigan's lower peninsula to the present area of Wisconsin. This displacement was the start of many movements westward for the Potawatomi (Mitchell, 1994, p. 3).

The Chicago Treaty of 1833 forced the Potawatomi from near Lake Michigan to move west to the Platte River area in northwestern Missouri. In 1837, the Potawatomi were moved out of the Platte River area because of the pressures of settlement and State officials who wanted to annex the land to the State of Missouri. This part of the Potawatomi Tribe was relocated to Council Bluffs, Iowa. Also in 1837 and in 1838 , large numbers of Potawatomi from northern Indiana were forced to live near the Marais des Cygne River in Linn County, Kansas. The group that went to Iowa eventually became the majority of the "Prairie Band of Potawatomi" (Prairie Band), whereas the other group that settled in east-central Kansas became the "Citizen Band of Potawatomi" (Citizen Band).

The Potawatomi in Iowa and east-central Kansas stayed in their respective areas for about 10 years. A treaty was signed in 1846 ceding their lands in exchange for a consolidated $900-\mathrm{mi}^{2}$ reservation, including the Kansas River west of present-day Topeka, west to Wabaunsee and Pottawatomie Counties and north to Jackson County (fig. 1). The consolidation and relocation to the new reservation started in 1847 (Mitchell, 1994, p. 23).

Shortly after the Potawatomi were relocated on lands in northeastern Kansas, the problems associated with pressures from settlers resurfaced. The Potawatomi were once again in the way of expansion, so some of the tribe was removed to Indian Territory in
Oklahoma. In 1861, a treaty opened up the Potawatomi lands for development as the Santa Fe Railroad acquired surplus acreages after allotments were made to tribal members (Kappler, 1972, p. 824). The tribal members who received allotments became known as the Citizen Band. The remaining Potawatomi became known as the Prairie Band. Today, the Prairie Band's reservation is separated from the Kansas River, in Jackson County, Kansas (fig. 1). After individual land sales, there were 18,459 acres of allotted land and 2,939.43 acres of tribal land (Brenda Shadwick, Bureau of Indian Affairs, written commun., 1991).

The present Sac and Fox Tribe originally was two distinct tribes. The Sacs came from the Upper Michigan Peninsula and the Fox from the south shore of Lake Superior (Brenda Shadwick, Bureau of Indian Affairs, written commun., 1991). In 1667, when the first recorded non-native contact was made with the two tribes, the Iroquois and French pressure on the Sacs and Chippewa pressure on the Fox pushed both groups to the vicinity of present-day Green Bay, Wisconsin. In the early 18th century, French attacks on the Sac and Fox drove both tribes to a close confederation (Hagan, 1958, p. 5). Forced to migrate south, those bands that stayed near the Mississippi River were called "Sac and Fox of the Mississippi" (Mississippi Band) to distinguish them from the "Sac and Fox of the Missouri" (Missouri Band), who migrated farther south and west to the Missouri River.

By the 1830's the Missouri Band was living in the northwest corner of Missouri with the Iowa Tribe. In 1836, the Missouri Band and the Iowa Tribe signed away their lands and settled for lands near the Great Nemaha River called the Great Nemaha Reservation in Doniphan and Brown Counties in Kansas and Richardson County in Nebraska (Sandra Keo, Sac and Fox Tribe, written commun., 1991). The Great Nemaha Reservation again was reduced by the Treaty of May 17, 1854. On March 6, 1861, a treaty between the United States and the Iowa Tribe ceded certain Iowa lands to the Sac and Fox Tribe. Today, the Sac and Fox Reservation is located west of the Iowa Reservation in Brown County, Kansas, and Richardson County, Nebraska (fig. 1) with 44.6 acres of allotted land and 509 acres of tribal land (Brenda Shadwick, Bureau of Indian Affairs, written commun., 1991).

The General Allotment Act of 1887, sometimes referred to as the Dawes Act, called for 160-acre plots of reservation land to be parceled out to the head of 
each Indian family. Eighty-acre and 40-acre plots of reservation lands also were parceled out to individual Indians. After the land was divided among the Indians, left-over or "surplus" lands were purchased by the U.S. Government. The purchase money was kept in trust for the Indian tribes and their members and appropriated for the purpose of educating and civilizing the tribe. The "surplus" lands then were sold to settlers and other interested groups, such as private land speculators, timber companies, and railroads. Later, the Indians were encouraged to sell their allotted land enabling settlers and other interested groups access to more Indian land (Cohen, 1982, p. 130-131). As a result, Indian reservations today are checkerboarded with Indian and non-Indian allotted lands.

\section{PHYSICAL SETTING}

\section{Physiography}

According to the major physical divisions of the United States defined by Fenneman (1938) and Fenneman and Johnson (1946), the study area is located in the Central Lowland Province of the Interior Plains. Schoewe (1949) further divided the Central Lowland Province in Kansas such that the study area lies mostly within the Dissected Till Plains Section but also includes a small area of the Osage Plains Section. These sections were divided further or modified by Schoewe (1949) into the Osage Cuestas, the Flint Hills Upland, the Kansas Drift Plains, and the Attenuated Drift Border (fig. 2). A discussion of these subdivisions as they relate to the study area follows.

The Osage Cuestas comprise the area south of the Kansas River as far west as Wabaunsee County and, in eastern Kansas, consist of at least 18 southwest-tonortheast irregularly trending east-facing escarpments between which are flat to gently rolling plains (Schoewe, 1949). The crest of each escarpment, ranging in height from less than $50 \mathrm{ft}$ to more than $200 \mathrm{ft}$, is capped by a resistant limestone underlain by weaker shale or sandstone.

The Flint Hills Upland is a north-south trending physiographic unit extending across the entire State; its eastern limit is generally defined by outcrops of flint-bearing limestone bedrock of Permian age. The Flint Hills Upland only occurs in the southwestern part of the study area. The surficial features, geologic structure, and erosional history of the upland are mostly the same as the topographically lower Osage Cuestas to the east.

The Dissected Till Plains, which covers most of the study area, occurs north of the Kansas River and is a northward extension of the Osage Plains because the underlying bedrock of both sections is identical. The basic difference between the two sections is that the Dissected Till Plains have been glaciated, but the Osage Plains have not. In the Dissected Till Plains, a mantle of drift conceals or covers the cuesta-type topography, which prevails in the Osage Cuestas to the south. Bedrock-controlled topography does not occur in the Dissected Till Plains except near its southern edge along the Kansas River Valley and on the west along the Big Blue River. This part of the Dissected Till Plains Section has been designated by Schoewe (1949) as the Attenuated Drift Border, and the rest of the section in Kansas is known as the Kansas Drift Plains.

Although the Attenuated Drift Border subdivision along the Big Blue, Little Blue, and Kansas River Valleys is glaciated and included in the Dissected Till Plains Section, the area has a bedrock-controlled type of topography and is mostly like the Flint Hills Upland and Osage Cuestas to the south. The area differs in that it has been glaciated and covered by isolated deposits of till, outwash, and erratics of ice-transported boulders, cobbles, and pebbles.

The topography of the Kansas Drift Plains reflects a gently undulating, drift-controlled, erosional surface. Distant from major streams, the broad, smooth, wellrounded, interstream areas are remnants of the uneroded original ground moraine deposited by the last retreating ice sheet. Beneath this surface lie glacial deposits of boulder till, sand and gravel, silt, and clay. The bedrock valleys with preglacial dendritic drainage patterns lie deeply buried by as much as $400 \mathrm{ft}$ of glacial deposits. Near larger stream valleys, the land surface becomes more dissected and is reduced to gentle slopes and broad and open valleys. Next to the larger stream valleys, the surface is very dissected, rough, and hilly, with steep valley walls of limestone and shale. The greatest topographic relief (300 ft) in the Kansas Drift Plains occurs in a narrow strip a few miles wide along the bluffs of the Missouri River where the upland surface is deeply incised into a very rugged region of hills between steep-sided valleys and ravines. Most drainage in the Kansas Drift Plains is to the Big Blue, Big Nemaha, Missouri, and Kansas Rivers. 


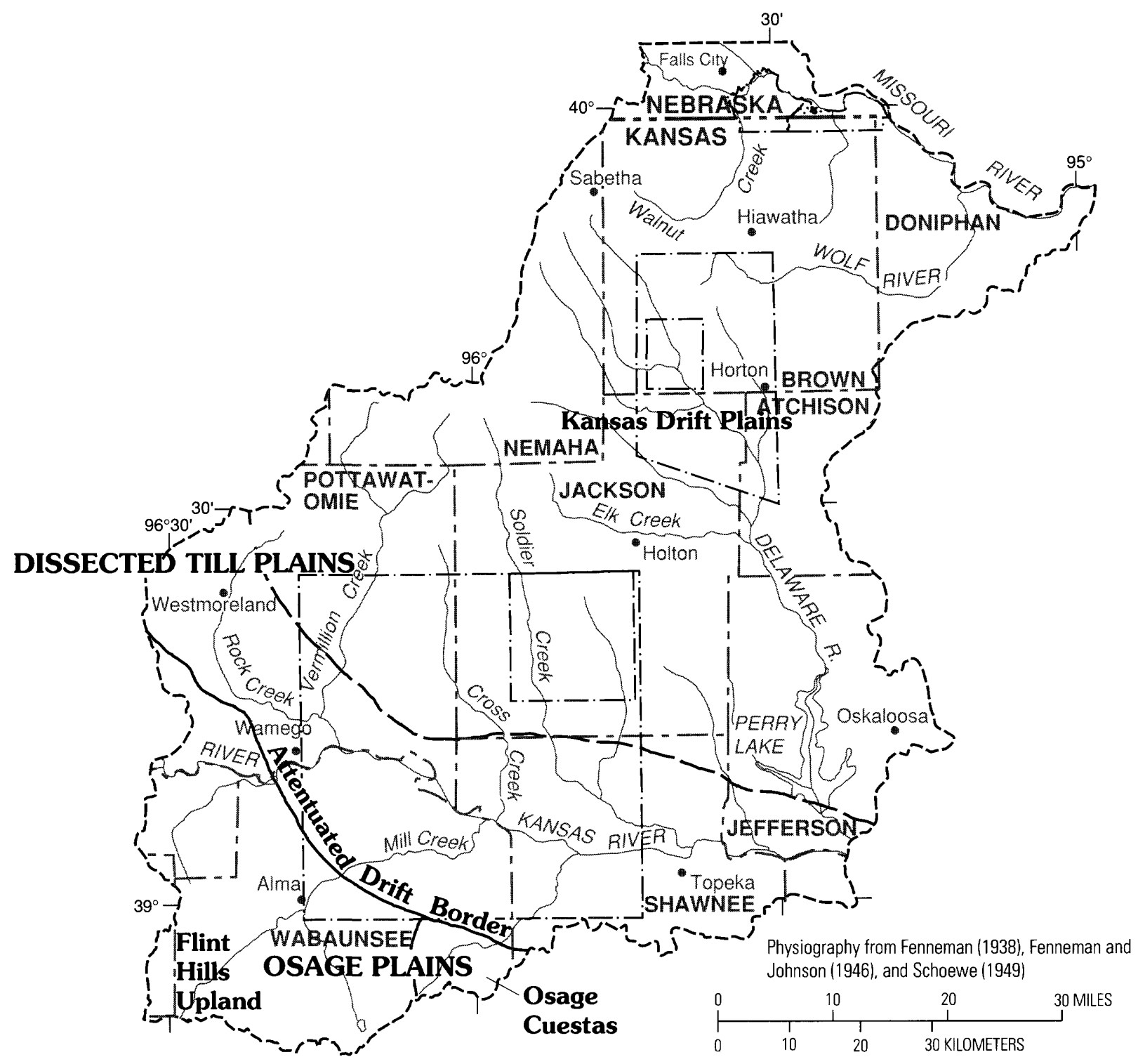

Base from U.S. Geological Survey digital data, 1:100,000, 1972 Lambert Conformal Conic projection EXPLANATION

Standard parallels $33^{\circ}$ and $45^{\circ}$

Boundary of physiographic section

- Boundary of subdivisions of physiographic sections

- - - - Boundary of study area

- - - - Boundary of Indian treaty lands - Boundaries are from U.S. Geological Survey 71/2-minute topographic quadrangles

Figure 2. Physiographic divisions of study area. 
The extreme northeastern part of the study area (Richardson County in Nebraska and parts of Brown and Doniphan Counties in Kansas) lies in the flood plain and terrace system associated with the Missouri River. The flood plain and low terraces of the Kansas River trend east-west in the southern part of the study area. Other areas of flood plains and low terraces occur along some of the larger tributaries of the Missouri and Kansas Rivers and include (1) Walnut Creek and the Wolf River in the Missouri River Basin and (2) Soldier Creek, Cross Creek, Mill Creek, Vermillion Creek, Rock Creek, and the Delaware River and its tributaries in the Kansas River Basin. Flood plains and terraces also may extend a short distance up the valleys of many of the smaller streams that are directly tributary to the Missouri and Kansas Rivers.

\section{Soils}

Certain physical characteristics of soils have a definite effect on the water resources of an area because they affect the rate at which precipitation infiltrates or is transmitted through the soil and thus help determine the rates of both ground-water recharge and surfacewater runoff.

Soil formation is a continuing process affected by environmental factors, including climate and biota, especially natural vegetation. Materials from which the soil is formed have a substantial effect on certain primary characteristics of the soil, such as texture, but climate, biotic factors, topographic position, and time determine the final character of the soil. The degree of weathering of the parent materials dictates the depth of soil development and the prevalence of clay and organic materials.

Typical parent materials for soils of the study area are loess, glacial till, alluvium, colluvium, eolian sand, shale, and limestone. Some physical characteristics, particularly average profile permeability and available water capacity of well-developed soils, reflect the parent materials on which the soils developed. The rate of soil development is affected by the nature of the parent materials. Consolidated sedimentary and crystalline bedrock usually weathers more slowly than unconsolidated materials, such as alluvium or loess, which already have certain characteristics similar to mature soils.

Climatic variations substantially affect soil development. The climate in the study area is a subhumid continental type where soils have developed at an intermediate rate. In the moister parts of the study area, many soils have clay accumulations that limit the soil permeability, thus restricting downward water movement.

Natural vegetation in the study area is diverse and related to the climate. The amount of organic matter in the soil is largely dependent on the decay of root systems. Grasslands, particularly tall-grass prairie, add large amounts of organic matter to the soil. Short-grass prairie produces less organic material; therefore, soils are lighter in color. Woodland soils usually have only a thin surface layer of organic matter, mostly from leaf decay; because root decay is much less under woodland conditions than under grassland conditions. Under warm, moist conditions leaching prevents the accumulation of organic matter in the upper soil horizons.

Topographic position of the soil is an important but passive factor in soil-forming process. Steep slopes tend to promote rapid runoff precipitation, decreasing the time available for infiltration, thus limiting the amount of water available for weathering of parent materials. Also, steep slopes tend to erode easily, thus resulting in thin, mostly undeveloped soils. The degree to which topographic position affects soil development is inversely dependent on the degree of the slope. In the study area, topography ranges from nearly flat, relatively large, continuous areas along and near divides or in the valley bottoms to steep slopes in the highly dissected bluff areas adjacent to the large river valleys.

The degree of soil development also depends partly on the length of time that geologic parent materials have been exposed to the climatic elements and to the intensity of weathering. It is nearly impossible to date the length of the soil-forming process at any particular place because of continuous addition of windor water-transported material or organic matter to the soil surface. The age of soils in the study area ranges from very young for flood-plain soils to very mature for soils long exposed on relatively flat uplands. The more mature soils are the most deeply developed with accumulations of clayey materials defined by leaching and redeposition.

Six soil characteristics that indicate the relation between soil and water were used by Dugan (1986) to evaluate the hydrologic responses of soil. Those six characteristics are: (1) average soil-profile permeability, (2) permeability of the least-permeable soil horizon, (3) average available water capacity, (4) soil 
slope, (5) depth to seasonal high water table, and

(6) thickness of the soil profile. A brief discussion of each of the six soil characteristics follows:

(1) Average permeability of the soil profile is the average vertical permeability of the individual soil horizons weighted by their thicknesses. Permeability is a measure of the rate at which water moves down through the saturated soil profile; it is affected by soil texture, structure, and porosity.

(2) Permeability of the least-permeable soil horizon within a particular soil profile is a measure of the degree by which vertical water movement is restricted within the soil. Existence of a restrictive layer is usually obscured by the average profile permeability.

(3) Average available water capacity of the soil profile is the difference between the quantity of water at field capacity (quantity of water held by unsaturated soil against the pull of gravity) and the quantity of water at the wilting point (point at which the water content of the soil becomes too low to prevent the permanent wilting of plants).

(4) Soil slope is the difference in elevation of the soil surface within a given horizontal distance expressed as a percentage. Dugan (1986) determined the slope value from the maximum slope of the range of slopes for a particular soil on the premise that in a particular area runoff is more a function of the greater rather than the lesser slopes.

(5) Depth to the seasonal high water table is the normal annual minimum depth to the water table and does not include any perched water tables. This factor is important in determining rates of evapotranspiration from certain soils. Long periods of saturation can change the structure of soils, which in turn, can affect other hydrologic soil characteristics, such as available water capacity and permeability.

(6) Thickness of the soil profile is used to distinguish between relatively thin soils (less than 60 in. thick) forming a veneer over bedrock and thicker soils (more than $60 \mathrm{in}$. thick) overlying unconsolidated or weakly consolidated parent material that is easily weathered. This soil characteristic can indicate the volume of water stored within the soil profile and its rate of movement out of or through this profile.

The discussion of soils in this report is based mostly on a study of the hydrologic characteristics of soils in parts or all of nine states in the central Midwest area of the United States (Dugan, 1986). The study was designed to provide data for the hydrologic characteristics of the region's soils to be used as input for a soil-moisture model that can be used to obtain estimates of actual evapotranspiration from and recharge to the regional aquifer system. The study has additional broad application for surface-water hydrology or for addressing hydrologic problems relating to agriculture. The data, however, are not detailed enough to make interpretations for an entire county or for smaller areas. For more detailed soil information, published large-scale $(1: 20,000)$, detailed county soilsurvey maps are available from the U.S. Department of Agriculture Soil Conservation Service for counties in the study area (see Bidwell and others, 1960; Eikleberry and Templin, 1960; Jantz and others, 1975; Campbell and others, 1979; Sallee, 1980; Kutnink and others, 1982; Sallee and Watts, 1984; Horsch and others, 1987).

A regional map of hydrologic characteristics of soils (Dugan, 1986) was compiled by generalizing the more detailed published soil-survey maps according to the range in hydrologic responses of each soil series. The soils then were grouped according to their hydrologic responses into 62 regional hydrologic soil groups, of which 10 occur in the study area (fig. 3, table 1). The method used for grouping the soils is described by Dugan (1984).

\section{Geology in Relation to Ground Water}

The ground-water hydrology of an area is dependent on the geology of that area. Knowledge of the geology, including the stratigraphy and geologic structure, leads to an improved understanding of the occurrence and availability of ground water. A brief description of the geology of the study area, as it relates to ground water, follows.

The study area lies within the stable interior of the North American continent. Since Precambrian time (about 600 million years ago), most of this part of the continent has undergone gentle deformation with upwarp and downwarp of the Earth's crust over large areas. Structurally, this part of the continent is characterized by broad basins and arches, with subtle folding of sedimentary rocks and few major fault zones (Jorgensen and others, 1993, p. B12 and fig. 15). The eastern and southern part of the study area lies in the Forest City Basin, separated from the Nemaha Uplift 


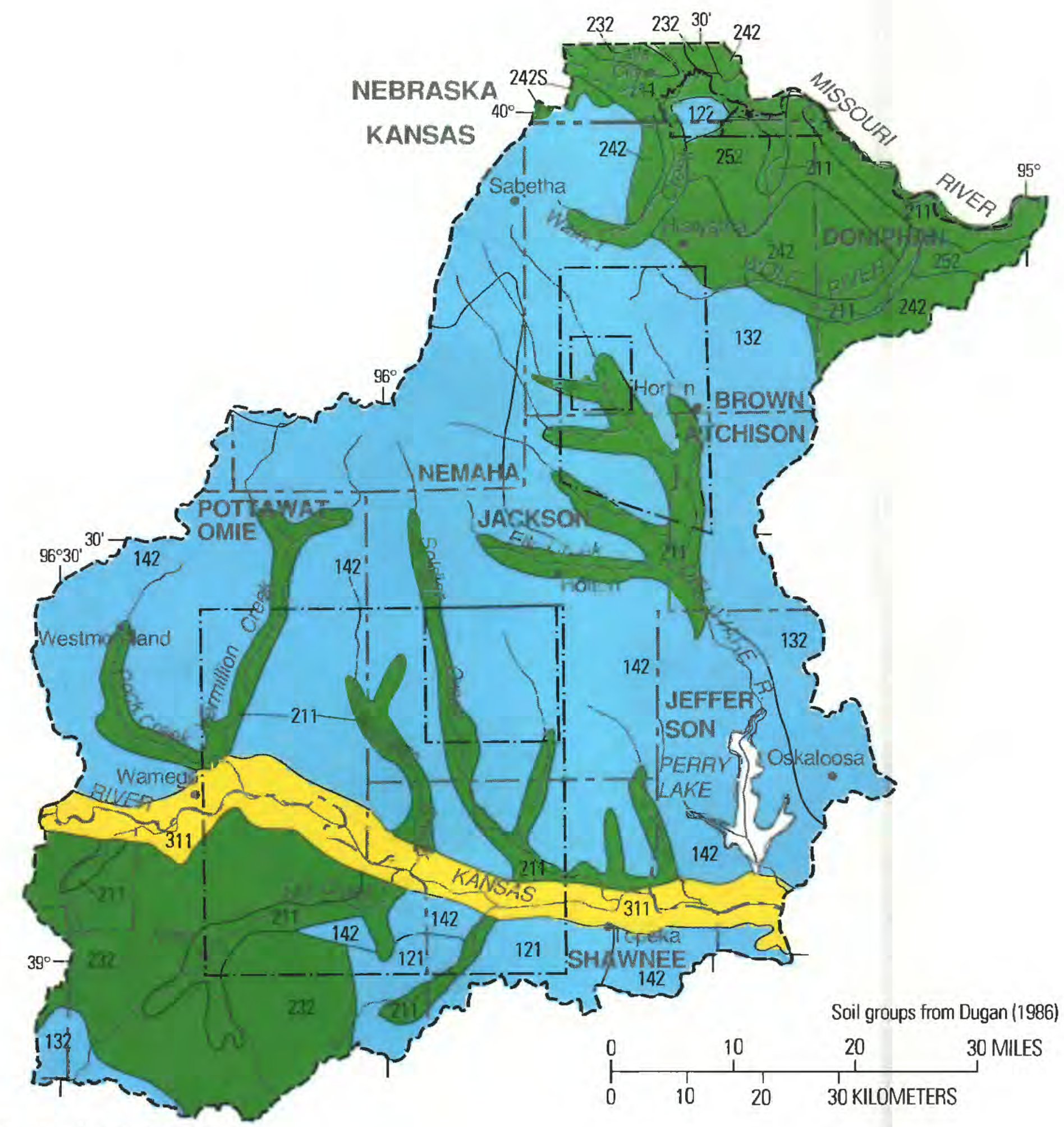

Base from U.S. Geological Survey digital data, 1:100,000, 1972

Lambert Conformal Conic projection

Standard parallels $33^{\circ}$ and $45^{\circ}$

\section{EXPLANATION}

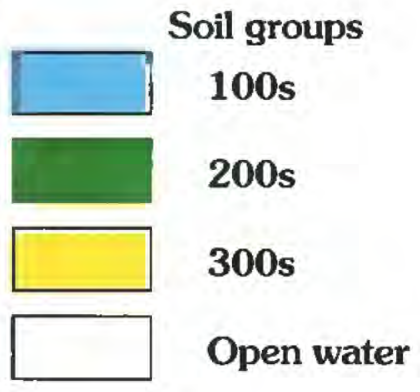

Figure 3. Hydrologic soil groups in study area.
211 Hydrologic soil group number-From Dugan (1986)

Contact between soil groups

Boundary of study area

Boundary of Indian treaty lands Boundaries are from U.S. Geological Survey $71 \frac{1}{2}$-minute topographic quadrangles 
[Data from Dugan (1986). >, greater than]

\begin{tabular}{|c|c|c|c|c|c|c|c|}
\hline $\begin{array}{l}\text { Hydro- } \\
\text { logic soil } \\
\text { group } \\
\text { number } \\
\text { (shown in } \\
\text { fig. 3) }\end{array}$ & $\begin{array}{l}\text { Average } \\
\text { profile per- } \\
\text { meability } \\
\text { (inch per } \\
\text { hour) }\end{array}$ & $\begin{array}{l}\text { Perme- } \\
\text { ability of } \\
\text { the ieast- } \\
\text { permeable } \\
\text { horizon } \\
\text { (inch per } \\
\text { hour) }\end{array}$ & $\begin{array}{c}\text { Average } \\
\text { proflle } \\
\text { available } \\
\text { water } \\
\text { capacity } \\
\text { (inch per } \\
\text { inch) }\end{array}$ & $\begin{array}{c}\text { Average } \\
\text { maximum } \\
\text { slope } \\
\text { (percent) }\end{array}$ & $\begin{array}{l}\text { Depth to } \\
\text { season- } \\
\text { ally high } \\
\text { water } \\
\text { table (feet) }\end{array}$ & $\begin{array}{c}\text { Soil } \\
\text { profile } \\
\text { thickness } \\
\text { (inches) }\end{array}$ & Description \\
\hline 121 & 0.15 & 0.07 & 0.17 & 6 & 2 & 60 & $\begin{array}{l}\text { Chiefly clay derived from weathered shale, } \\
\text { clayey glacial till, high clay-content loess, or } \\
\text { clayey alluvium. Average permeabilities are } \\
\text { very slight; available water capacities are } \\
\text { moderate to low. Nearly level to steeply slop- } \\
\text { ing. Occur on some flood plains and terraces. } \\
\text { Water table lies near the land surface season- } \\
\text { ally or in all seasons because of significant } \\
\text { ground-water recharge. }\end{array}$ \\
\hline 122 & .30 & .20 & .16 & 6 & $>6$ & 65 & $\begin{array}{l}\text { Mostly clay derived from weathered shale, } \\
\text { clayey glacial till, high clay-content loess, or } \\
\text { clayey alluvium. Very slight permeabilities; } \\
\text { moderate to low available water capacities. } \\
\text { Nearly level to steeply sloping. Occur on ter- } \\
\text { races and tablelands. Permanent water table } \\
\text { lies much below the land surface in all sea- } \\
\text { sons. }\end{array}$ \\
\hline
\end{tabular}

Clay derived from weathered shale, clayey glacial till, high clay-content loess, or clayey alluvium. Very slight permeabilities; moderate to low available water capacities. Very gentle to moderately steep slopes. Occur on terraces or rolling uplands. Permanent water table lies much below the land surface in all seasons.

Mainly clay derived from shale, clayey glacial till, high clay-content loess, or clayey alluvium. Very slight permeabilities; low to moderate available water capacities. Gently to steeply sloping. Occur on dissected or eroded uplands. Permanent water table is much below the land surface in all seasons.

Silty clay loam to silt loam derived mostly from silty loess or silty alluvium. Slight permeabilities; moderate to high available water capacities. Level to very gently sloping. Occur on the flood plains and terraces of the Missouri River and its tributaries, and along tributaries of the Kansas River. Water table lies near the land surface seasonally or in all seasons because of significant ground-water recharge. 
Table 1. Hydrologic characteristics of soils in the study area-Continued

\begin{tabular}{|c|c|c|c|c|c|c|c|}
\hline $\begin{array}{l}\text { Hydro- } \\
\text { logic soil } \\
\text { group } \\
\text { number } \\
\text { (shown in } \\
\text { fig. 3) }\end{array}$ & $\begin{array}{l}\text { Average } \\
\text { profile per- } \\
\text { meability } \\
\text { (inch per } \\
\text { hour) }\end{array}$ & $\begin{array}{l}\text { Perme- } \\
\text { ability of } \\
\text { the least- } \\
\text { permeable } \\
\text { horizon } \\
\text { (inch per } \\
\text { hour) }\end{array}$ & $\begin{array}{l}\text { Average } \\
\text { profile } \\
\text { available } \\
\text { water } \\
\text { capacity } \\
\text { (inch per } \\
\text { inch) }\end{array}$ & $\begin{array}{l}\text { Average } \\
\text { maximum } \\
\text { slope } \\
\text { (percent) }\end{array}$ & $\begin{array}{l}\text { Depth to } \\
\text { season- } \\
\text { ally high } \\
\text { water } \\
\text { table (feet) }\end{array}$ & $\begin{array}{l}\text { Soil } \\
\text { profile } \\
\text { thickness } \\
\text { (inches) }\end{array}$ & Description \\
\hline 232 & 0.96 & 0.77 & 0.18 & 12 & $>6$ & 62 & $\begin{array}{l}\text { Silty clay loam to silt loam derived from silty } \\
\text { loess or silty alluvium. Slight permeabilities; } \\
\text { moderate to high avaiiable water capacities. } \\
\text { Very gentle to moderately steep slopes. Occur } \\
\text { on terraces or rolling uplands. Permanent } \\
\text { water table lies well below the land surface in } \\
\text { all seasons. }\end{array}$ \\
\hline 242 & 1.02 & .82 & .16 & 23 & $>6$ & 64 & $\begin{array}{l}\text { Silty clay loam to silt loam derived from silty } \\
\text { loess or silty alluvium. Slight permeabilities; } \\
\text { moderate to high available water capacities. } \\
\text { Gently to steeply sloping. Occur on dissected } \\
\text { or eroded uplands. Permanent water table lies } \\
\text { well below the land surface in all seasons. }\end{array}$ \\
\hline $242 S$ & .94 & .87 & .16 & 22 & $>6$ & 46 & $\begin{array}{l}\text { Similar to soil group } 242 \text { except soils are } \\
\text { shallow; directly overlie slightly weathered } \\
\text { or resistant bedrock. }\end{array}$ \\
\hline 252 & 1.25 & 1.22 & .19 & 40 & $>6$ & 63 & $\begin{array}{l}\text { Silty clay loam to silt loam derived from silty } \\
\text { loess or silty alluvium. Slight permeabilities; } \\
\text { moderate to high available water capacities. } \\
\text { Gentle to very steep slopes. Occur on highly } \\
\text { dissected uplands. Permanent water table lies } \\
\text { well below the land surface in all seasons. }\end{array}$ \\
\hline 311 & 2.13 & .88 & .18 & 2 & 2 & 63 & $\begin{array}{l}\text { Silty clay to loam derived from silty sandy } \\
\text { loess and silty sandy alluvium. Moderate per- } \\
\text { meabilities; moderate to high available water } \\
\text { capacities. Level to very gently sloping. } \\
\text { Occur on flood plains and terraces along the } \\
\text { Kansas River. Permanent water table lies near } \\
\text { or at the land surface seasonally or in all sea- } \\
\text { sons on the flood plain or on the terraces. }\end{array}$ \\
\hline
\end{tabular}


in the western part of the area (fig. 4) by an approximately 2,000-ft-vertical offset fault zone (fig. 5).

Undifferentiated Precambrian igneous and metamorphic basement rocks lie deeply buried in the study area (fig. 6) beneath approximately 500 to $3,500 \mathrm{ft}$ of Paleozoic and Cenozoic sedimentary rocks (Merriam, 1963). As shown in the east-west geohydrologic section (fig. 5), the Precambrian basement confining unit underlies Mississippian through Cambrian rocks (Western Interior Plains aquifer system) deep in the Forest City Basin, but directly underlie Permian and Pennsylvanian rocks (Western Interior Plains confining system) over the Nemaha Anticline. Because the surface of the Precambrian basement confining unit has been faulted, deeply weathered, and eroded, the rocks commonly are fractured and covered by residual material. The sedimentary rocks that overlie the Precambrian basement confining unit range from Cambrian to Quaternary in age and are summarized in table 2.
Paleozoic rocks in the study area unconformably overlie the Precambrian basement rocks and include rocks of Cambrian, Ordovician, Silurian, Devonian, Mississippian, Pennsylvanian, and Permian age, including shale, limestone, dolostone, sandstone, coal, and evaporite beds (Merriam, 1963). The study area was above sea level from the end of the Precambrian to Late Cambrian time, and an uneven erosional surface had developed on the fractured crystalline Precambrian rocks. Beginning in late Cambrian time, the seas advanced over the area repeatedly, resulting in a thick sequence of strata. The lower part of these rocks has been designated by Jorgensen and others (1993) as the Western Interior Plains aquifer system, which includes mostly carbonate rocks of Cambrian through Mississippian age. The upper part of the Paleozoic sequence, designated the Western Interior Plains confining system, includes mostly shale and siltstone, with minor sandstone, limestone, coal, and evaporite deposits of upper Mississippian through Permian age. Some of these rocks are present at land surface in

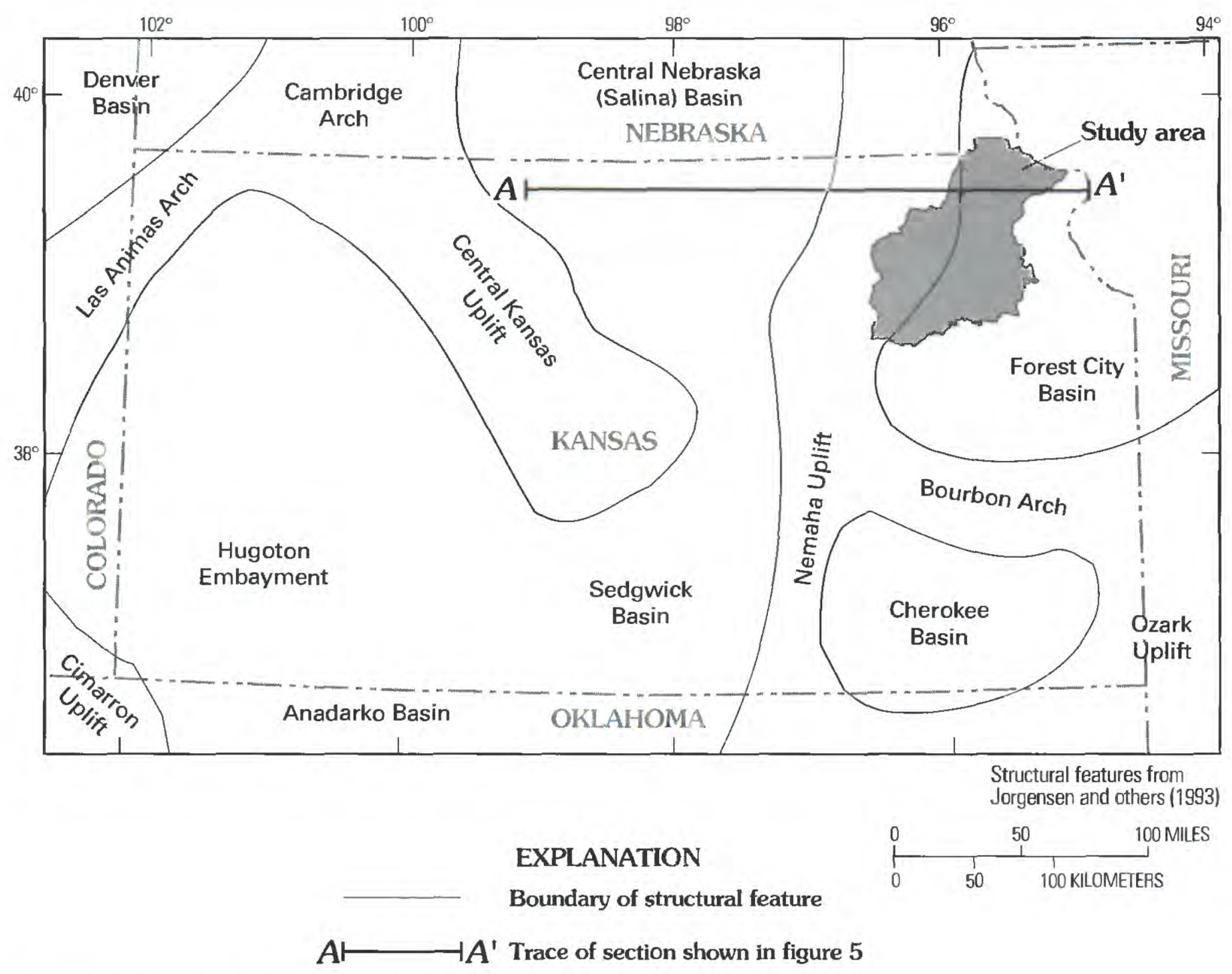

Figure 4. Geologic structural features in and near study area. 


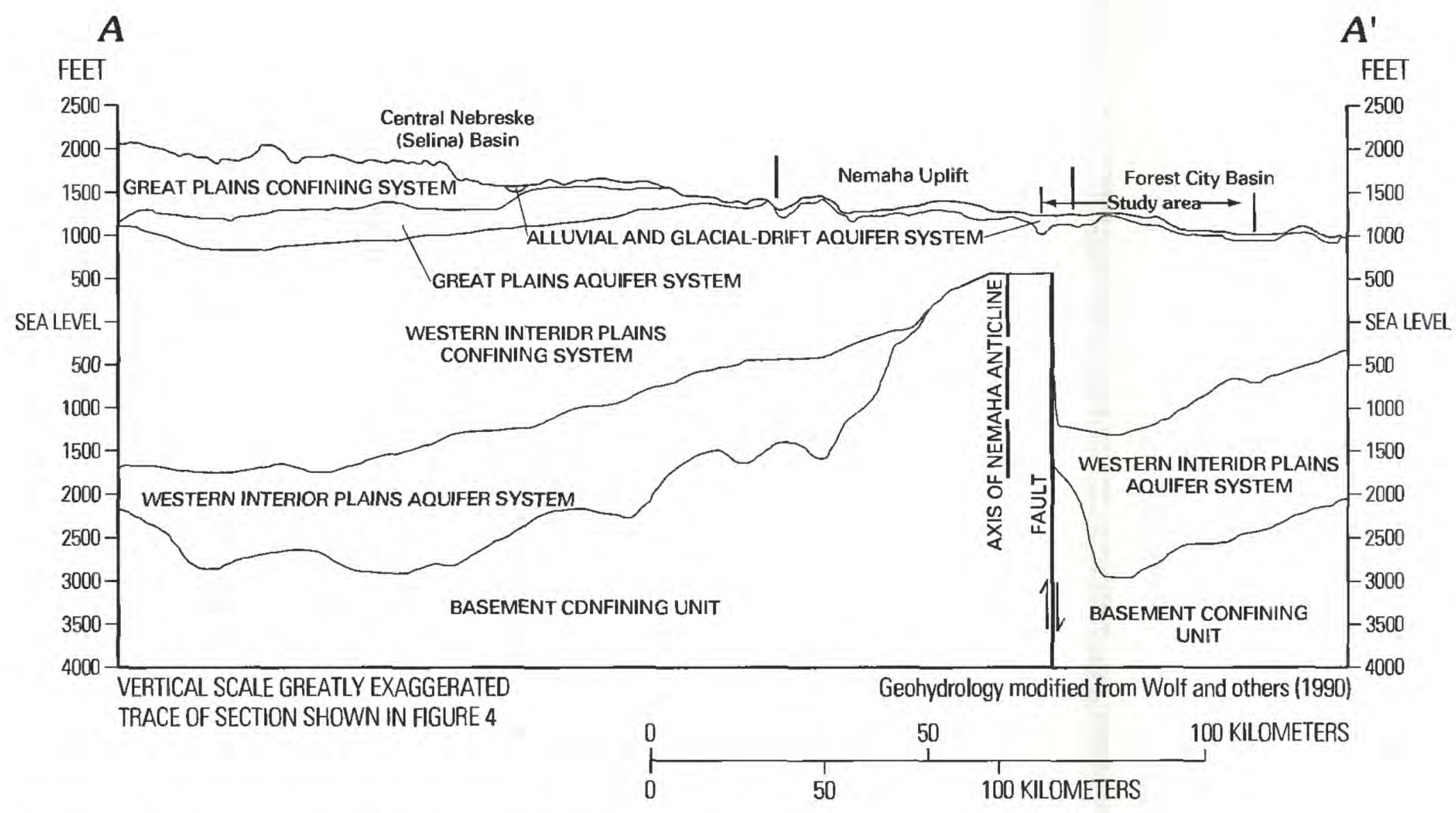

Figure 5. East-west geohydrologic section across study area.

much of the southern part of the study area and beneath the alluvial, eolian, and glacial deposits in the rest of the study area (fig. 7).

Rocks of Mesozoic age are absent in the study area because land in this area was emergent during most of the Mesozoic. Although there was some deposition that occurred during the Mesozoic, the deposits were subsequently eroded before deposition of younger Cenozoic sediments (Jorgensen and others, 1993).

Unconsolidated alluvial, eolian, and glacial deposits of Quaternary age unconformably overlie the erosional surface of the Paleozoic sedimentary rocks. Quaternary deposits include sediments of both Pleistocene and Holocene age but were not differentiated in this study. The Quarternary deposits are present throughout much of the northern part of the study area (fig. 7), except in small areas, such as along some stream embankments, steep hillsides, or roadcuts, where the Paleozoic sedimentary rocks crop out. In the southern part of the study area, the Quaternary deposits occur mainly as alluviam in the valleys and as glacial deposits in some interstream areas. The lithology of the Quaternary deposits is variable vertically and horizontally and ranges from fine-grained sediments of till, silt, and clay to coarse-grained sediments of sand, gravel, pebbles, cobbles, and boulders.

\section{Climate}

Located in the Interior Plains (Fenneman, 1938), northeastern Kansas and southeastern Nebraska have a typical continental climate that is characterized by large variations in temperature and precipitation throughout the year and from year to year. This part of the Interior Plains is classified as moist subhumid by Thornthwaite (1941) but can range from semiarid to humid for any given year (Eagleman, 1975). Daily precipitation often exceeds daily evapotranspiration in this area, with the excess either becoming runoff or entering the soil to become ground water. During intervals of precipitation deficiency and high temperatures, evapotranspiration can remove large quantities of surface water and shallow soil water resulting in drought conditions.

The long-term average annual precipitation (1888-1991) for Horton, Kansas, of 34.23 in. (National Oceanic and Atmospheric Administration, 1992-94) is representative of the study area. Slightly more than 70 percent of the annual precipitation comes during the April-to-September growing season (fig. 8A). One year out of four will have less than 28 in. of precipitation, and one out of four will have more than 40 in. The driest year on record was 1988 when only 19.31 in. of precipitation fell, and the wettest year was 1951 with 62.64 in. of precipitation. The 


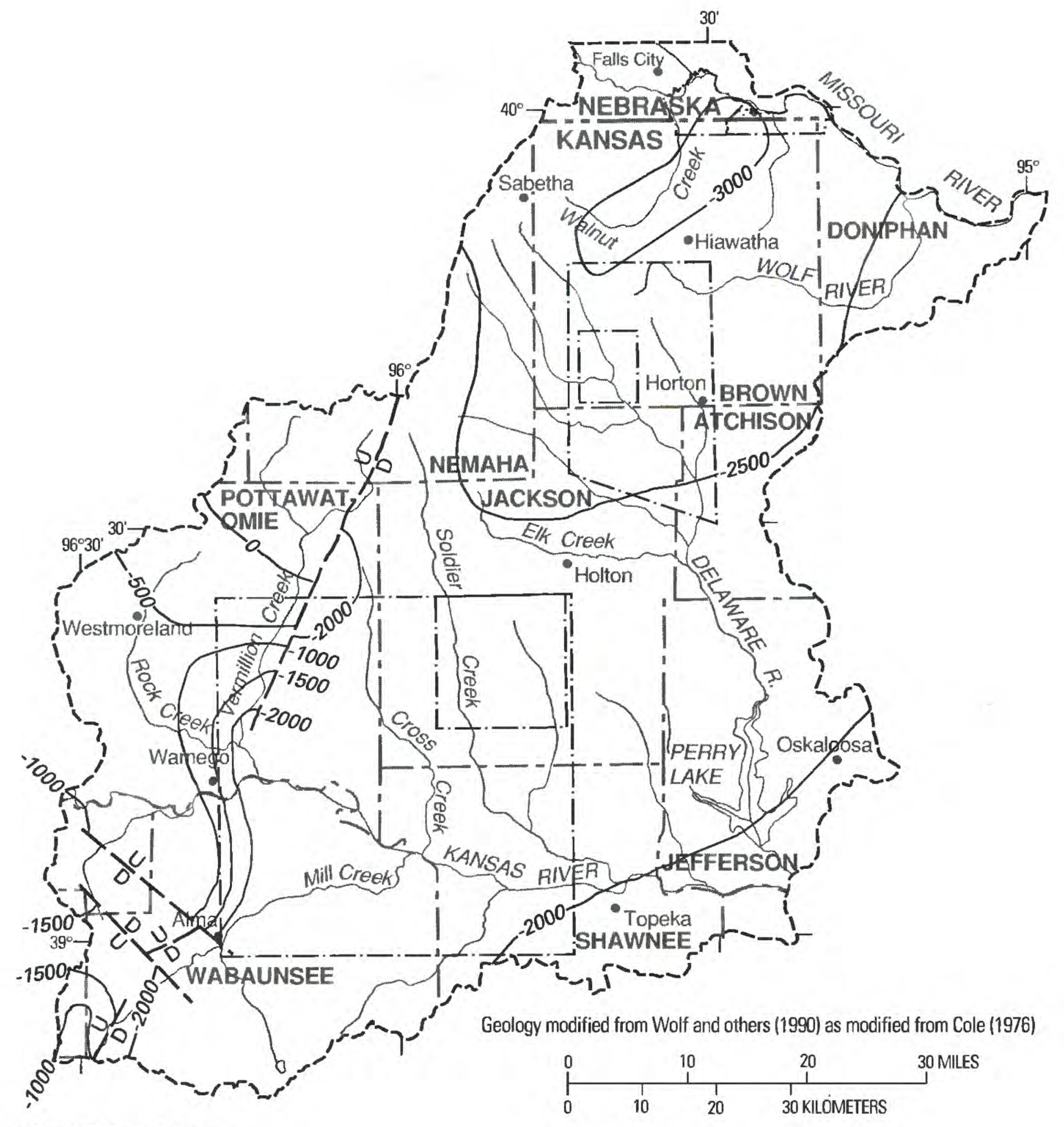

Base from U.S. Geological Survey

digital data, 1:100,000, 1972

Lambert Conformal Conic projection

Standard parallels $33^{\circ}$ and $45^{\circ}$

\section{EXPLANATION}

- 2000 - Basement contour-Shows altitude of top of Precambrian rocks. Contour interval 500 and 1,000 feet. Datum is sea level

- $\frac{U}{D}-$ Fault-U, upthrown side; D, downthrown side

----- Boundary of study area

- - - Boundary of Indian treaty lands - Boundaries are from U.S. Geological Survey 71/2-minute topographic quadrangles

Figure 6. Altitude and configuration of top of Precambrian rocks in study area. 
Table 2. Geohydrologic systems and associated water-bearing characteristics in and near the study area [gal/min, gallons per minute]

\begin{tabular}{|c|c|c|c|c|}
\hline $\begin{array}{c}\text { Era } \\
\text { (geologic } \\
\text { time } \\
\text { scale) }\end{array}$ & $\begin{array}{l}\text { Geologic } \\
\text { system }\end{array}$ & $\begin{array}{l}\text { Geohydro- } \\
\text { logic } \\
\text { system² }\end{array}$ & $\begin{array}{l}\text { Character and } \\
\text { distribution }\end{array}$ & $\begin{array}{l}\text { Water-bearing } \\
\text { characteristics }\end{array}$ \\
\hline 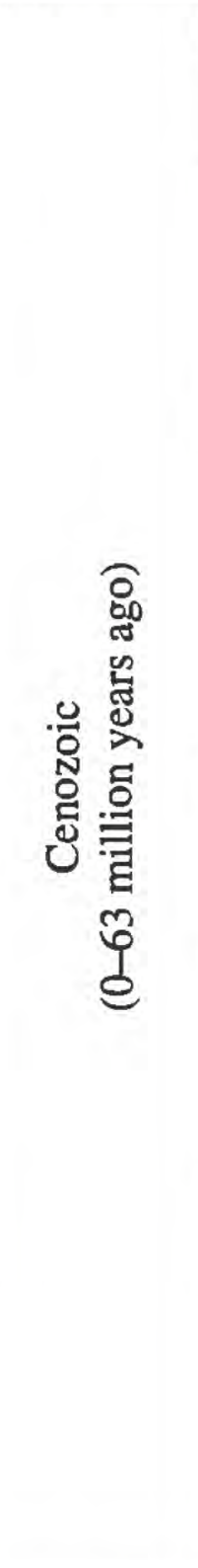 & 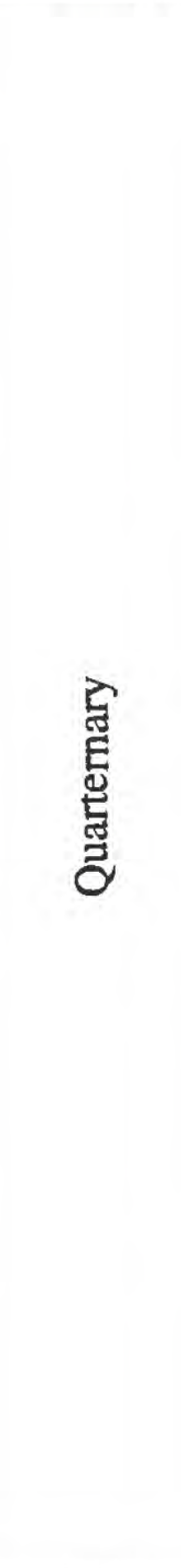 & $\begin{array}{c}\text { Alluvial and } \\
\text { glacial-drift } \\
\text { aquifer } \\
\text { system }\end{array}$ & $\begin{array}{l}\text { Alluvial deposits: } \\
\text { Includes sand, gravel, silt, and clay. } \\
\text { These deposits are most continuous } \\
\text { and thickest beneath flood plains } \\
\text { and terraces of major streams. } \\
\text { Along the smaller stream valleys, } \\
\text { alluvial deposits are mostly silt and } \\
\text { clay but may contain coarser basal } \\
\text { deposits capable of yielding moder- } \\
\text { ate water supplies. In the upland } \\
\text { areas, discontinuous alluvial depos- } \\
\text { its are variable. } \\
\text { Eolian deposits: } \\
\text { Mostly loess deposits consisting of } \\
\text { silt and clayey silt that make up the } \\
\text { surficial materials in the upland } \\
\text { areas and are thickest near the } \\
\text { larger streams. } \\
\text { Glacial deposits: } \\
\text { Till deposits consisting of poorly } \\
\text { sorted silt, clay, and broken pieces } \\
\text { of shale, as well as pebbles and } \\
\text { fragments of sandstone, limestone, } \\
\text { quartzite, and other rock types. } \\
\text { Only occur in upland part of the } \\
\text { study area. }\end{array}$ & $\begin{array}{l}\text { Kansas River Valley alluvial } \\
\text { aquifer-well yields generally are } \\
300 \text { to } 2,500 \text { gal/min. Restricted to } \\
\text { deposits underlying the flood plain } \\
\text { and terraces along the Kansas River. } \\
\text { Missouri River Valley alluvial } \\
\text { aquifer-well yields generally are } \\
150 \text { to } 3,000 \text { gal/min. Restricted to } \\
\text { deposits underlying the flood plain } \\
\text { and terraces along the Missouri } \\
\text { River. In smaller stream-valley allu- } \\
\text { vial aquifers well yields are generally } \\
\text { less than } 300 \text { gal/min. } \\
\text { Surface deposits that are usually } \\
\text { above the water table and serve as a } \\
\text { transmission medium for precipita- } \\
\text { tion to percolate as recharge to the } \\
\text { water table. Note: Not usually satu- } \\
\text { rated. } \\
\text { Nearly impermeable deposits that } \\
\text { locally may be a semiconfining layer } \\
\text { for underlying and interfingering } \\
\text { alluvial sand and gravel deposits. } \\
\text { May yield as much as } 900 \text { gal/min, } \\
\text { but less than } 500 \text { gal/min is more } \\
\text { common. }\end{array}$ \\
\hline 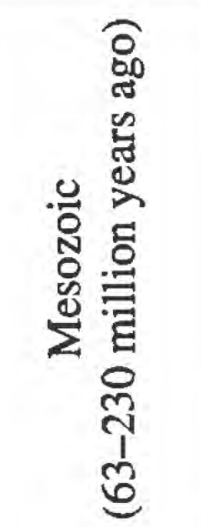 & 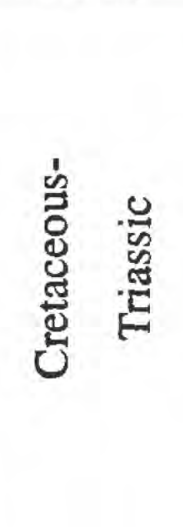 & $\begin{array}{c}\text { Great Plains } \\
\text { aquifer } \\
\text { system }\end{array}$ & Absent in study area. & Absent in study area. \\
\hline
\end{tabular}


Table 2. Geohydrologic systems and associated water-beaning characteristics in and near the study area-Continued

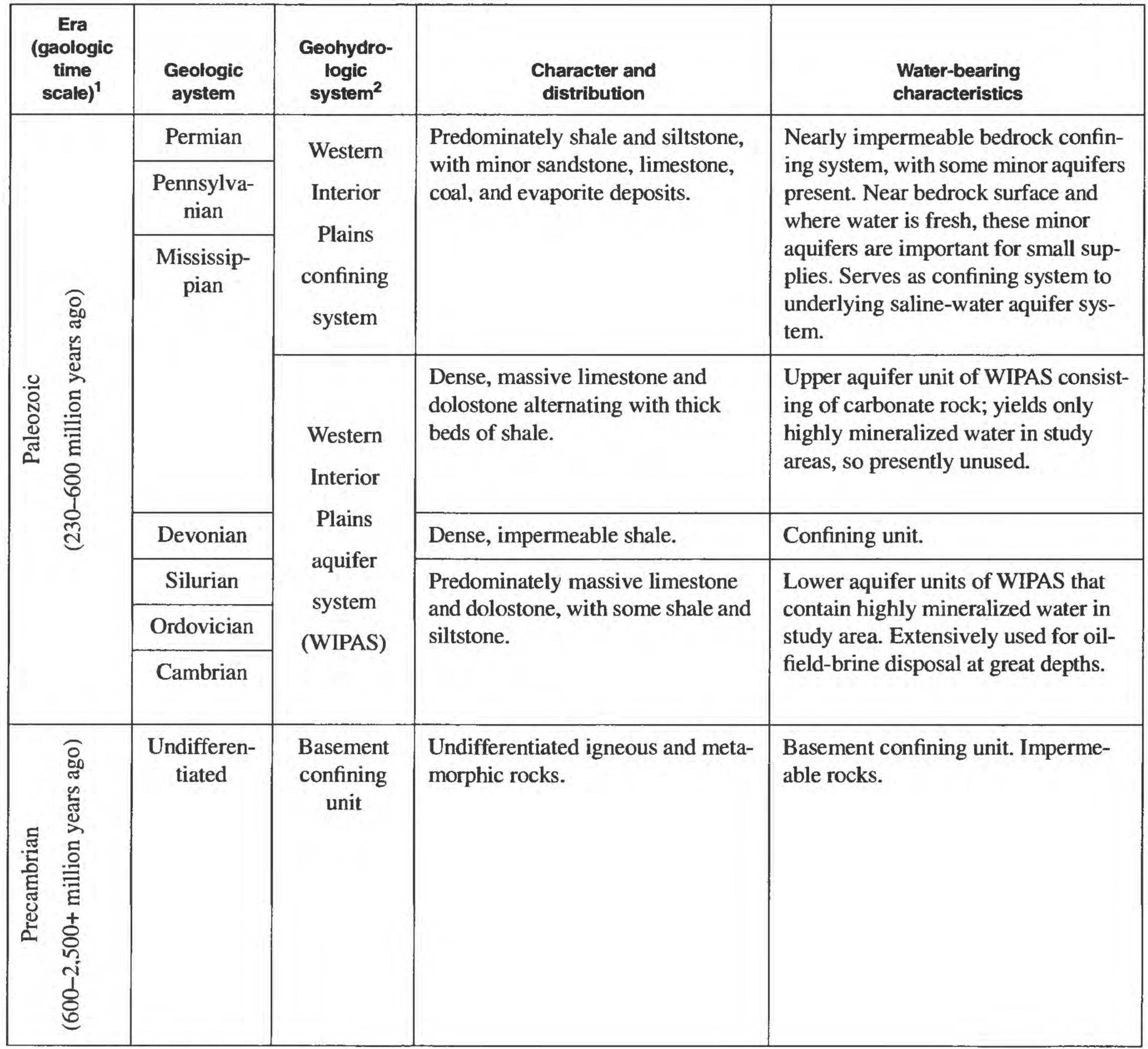

${ }^{1}$ Geologic time scale from Holmes (1959).

${ }^{2}$ Modified from Wolf and others (1990). 


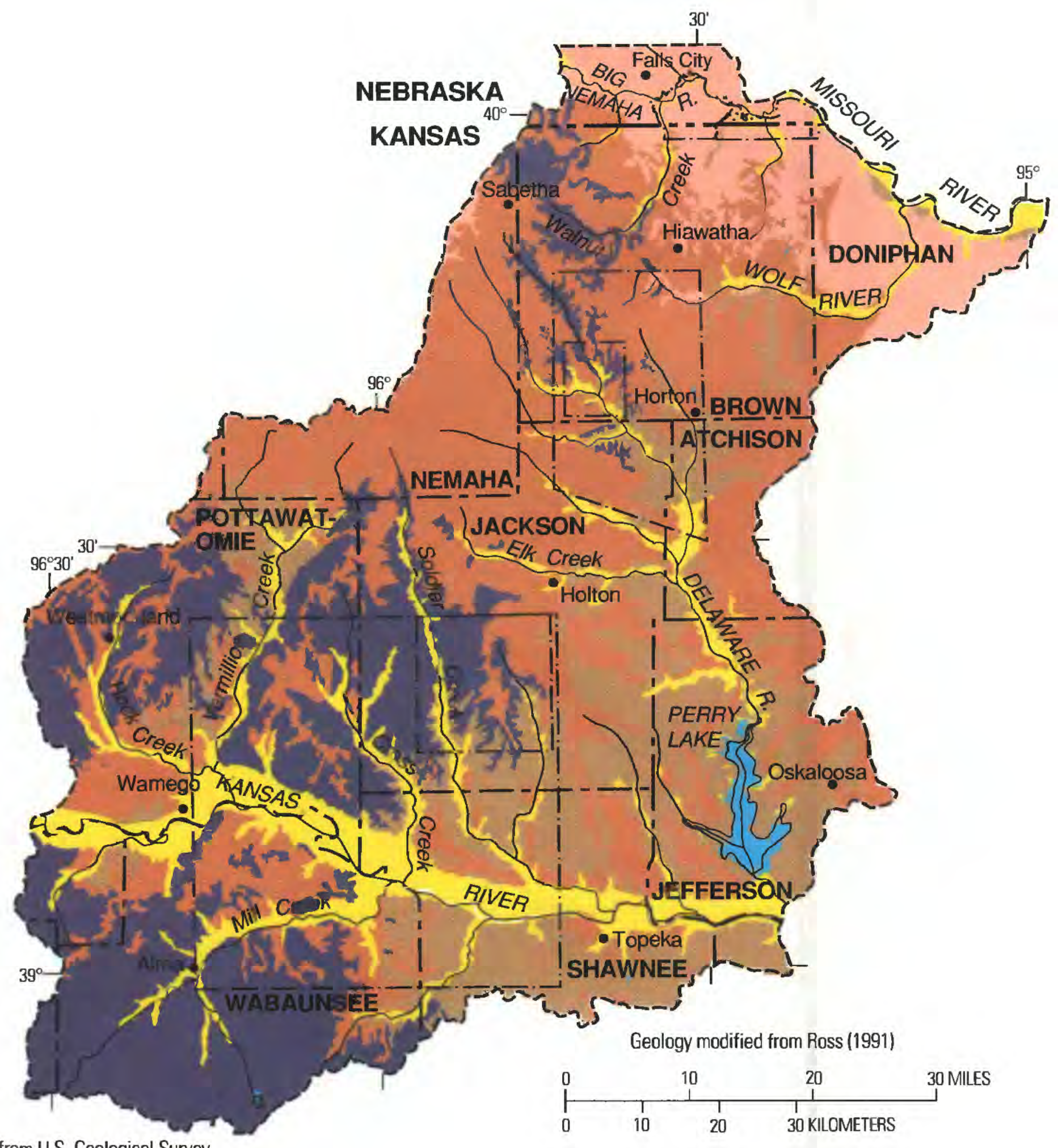

Base from U.S. Geological Survey

digital data, 1:100,000, 1972

Lambert Conformal Conic projection

Standard parallels $33^{\circ}$ and $45^{\circ}$

\section{EXPLANATION}

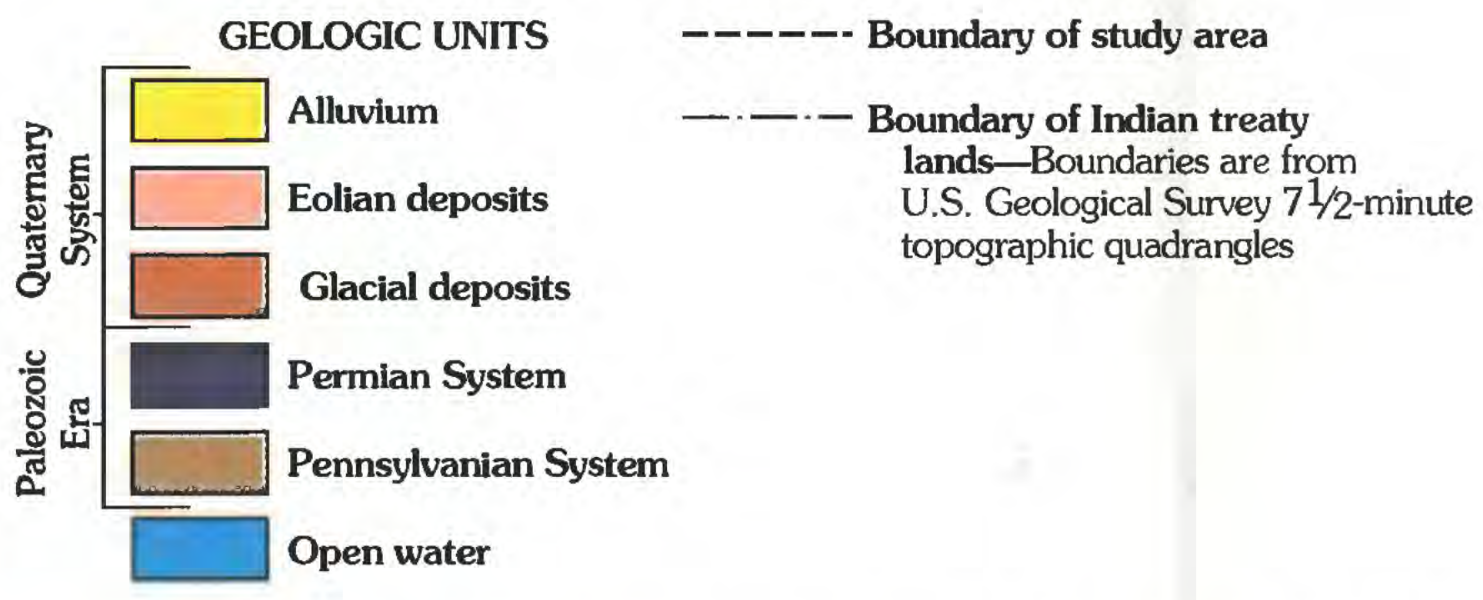

Flgure 7. Upper Paleozoic rocks and Cenozoic deposits present at the surface of the study area. 

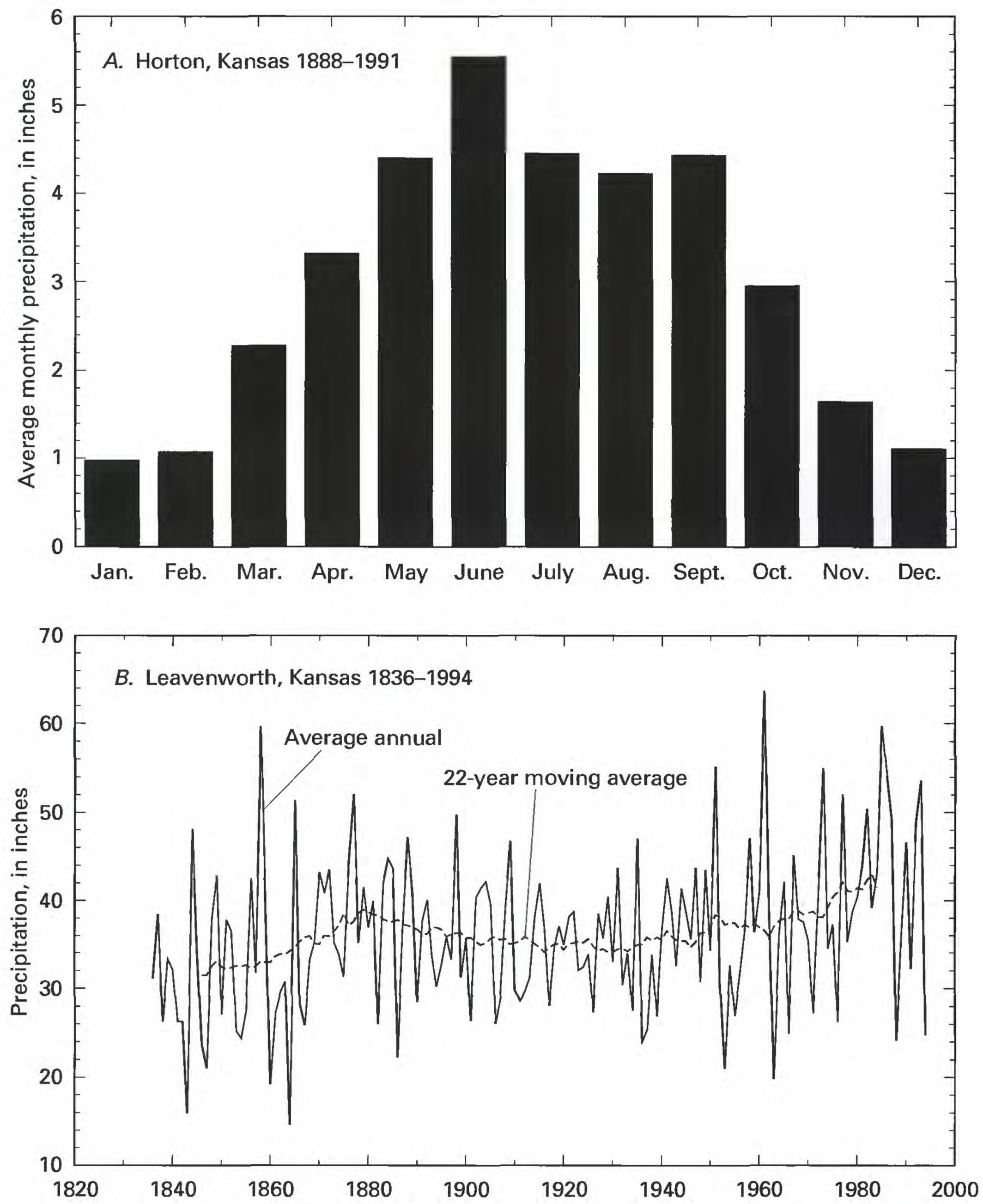

Figure 8. Average monthly precipitation for (A) Horton, Kansas, 1888-1991, and (B) average annual precipitation and 22-year moving average precipitation for Leavenworth, Kansas, 1836-1994 (data from National Oceanic and Atmospheric Administration, 1992-94). 
precipitation record at Horton is quite similar to that for Leavenworth, Kansas (east of study area, fig. 1), which extends back to 1836 . Smoothed precipitation data using a 22-year moving average for annual precipitation at Leavenworth went from a low in the 1840 's to a peak in the 1870's and back to another low in the 1930's (fig. 8B). By the 1980's, the 22-year moving average for Leavenworth increased again, surpassing the 1880 peak. Year-to-year precipitation variability was high during the 1860 's, lowest during the 1920 's, and high again after 1950 (fig. 8B).

Temperatures for Horton, Kansas, also are representative of the study area, with the monthly mean maximum temperatures ranging from $35.7^{\circ} \mathrm{F}$ in January to $90.3^{\circ} \mathrm{F}$ in July (fig. 9). Monthly mean minimum temperatures range from $13.6^{\circ} \mathrm{F}$ in January to $66.2^{\circ} \mathrm{F}$ in July. The lowest monthly mean temperature for the period of record (1988-1991) was $10.9^{\circ} \mathrm{F}$ in January 1940 , and the highest monthly mean temperature occurred in July 1934 with $87.4^{\circ} \mathrm{F}$.

There is a relation between mean summer (June-August) precipitation and mean summer temperatures (fig. 10), and this relation is common to the central part of the United States (U.S. Department of Commerce, 1968, p. 63). A negative correlation coefficient of -0.68 , significant at the 1-percent level, shows that hot summers usually have less rainfall. This relation explains the likelihood of drought conditions developing during hot summers because warmer temperatures increase evapotranspiration. Average free water-surface evaporation for northeast Kansas is approximately 33 in. from May to October and about 45 in. for the year.

\section{Land Cover and Land Use}

Present land cover in the study area is very different from the original vegetative cover that existed prior to the influx of native tribes relocated from the east in the early to middle 1800 's followed by the influx of non-native settlers in the middle 19th century. These changes in land cover were due to: (1) massive conversion of native vegetative cover to agricultural uses, (2) wildfire suppression, which favored more woodland cover over prairie cover, and (3) the introduction of exotic (non-native) plant and animal species to the region (Dickey and others, 1977).

Wyandotte County, located just two counties east of the study area on the eastern boundary of Kansas, was about 50-percent forestland prior to settlement, although it was the most forested county in the State. Midway across Kansas and farther west, more than 97 percent of the land was prairie, with forested areas restricted to riparian corridors along the stream courses. Jefferson County, Kansas, which is on the eastern side of the study area, was originally about 15to 20-percent forestland (Dickey and others, 1977). The original vegetation on the uplands was mostly very diverse, tall-grass prairie. The original vegetation on the bottom land and along small drainageways was a lowland plains hardwood association, and in some poorly drained areas, water-tolerant tall-grass prairie species thrived.

Present land use in the study area (fig. 11) is dominantly agricultural (mostly cropland or pastureland, but includes orchards, nurseries, confined feeding operations, and other agricultural use). Forestland, which occurs mostly in the eastern half of the study area, is minor but is the second most important land cover in this part of the study area. Forestlands may have been more widespread than that before extensive settlement. In the study area, the largest forestland areas are along the Missouri River and around Perry Lake. Other smaller forestland areas are found scattered throughout the eastern part of the study area, mostly as riparian forestlands along rivers and streams, and as individual shelterbelt, fence-row, or woodlot areas.

In the western half of the study area, rangeland is the second most prevalent land use, after agricultural land. In the southwestern part of the study area, especially in the area south of the Kansas River, rangeland is the dominant land use. Minor urban areas (towns) are scattered throughout the study area. One major urban area, the city of Topeka and the surrounding suburban area, occurs in the southern part of the study area. One major reservoir, Perry Lake on the Delaware River, occurs within the study area. A major wetland area, Squaw Creek Wildlife Refuge, lies just across the Missouri River northeast of the study area. Most wetland areas within the study area have been drained by ditching and tiling to provide agriculture fields for crops.

\section{METHODS OF INVESTIGATION}

Existing data from the USGS, the Kansas Geological Survey, and other agencies provided the basis for this water-resource overview of the study area. Seasonal trends in low streamflows were 


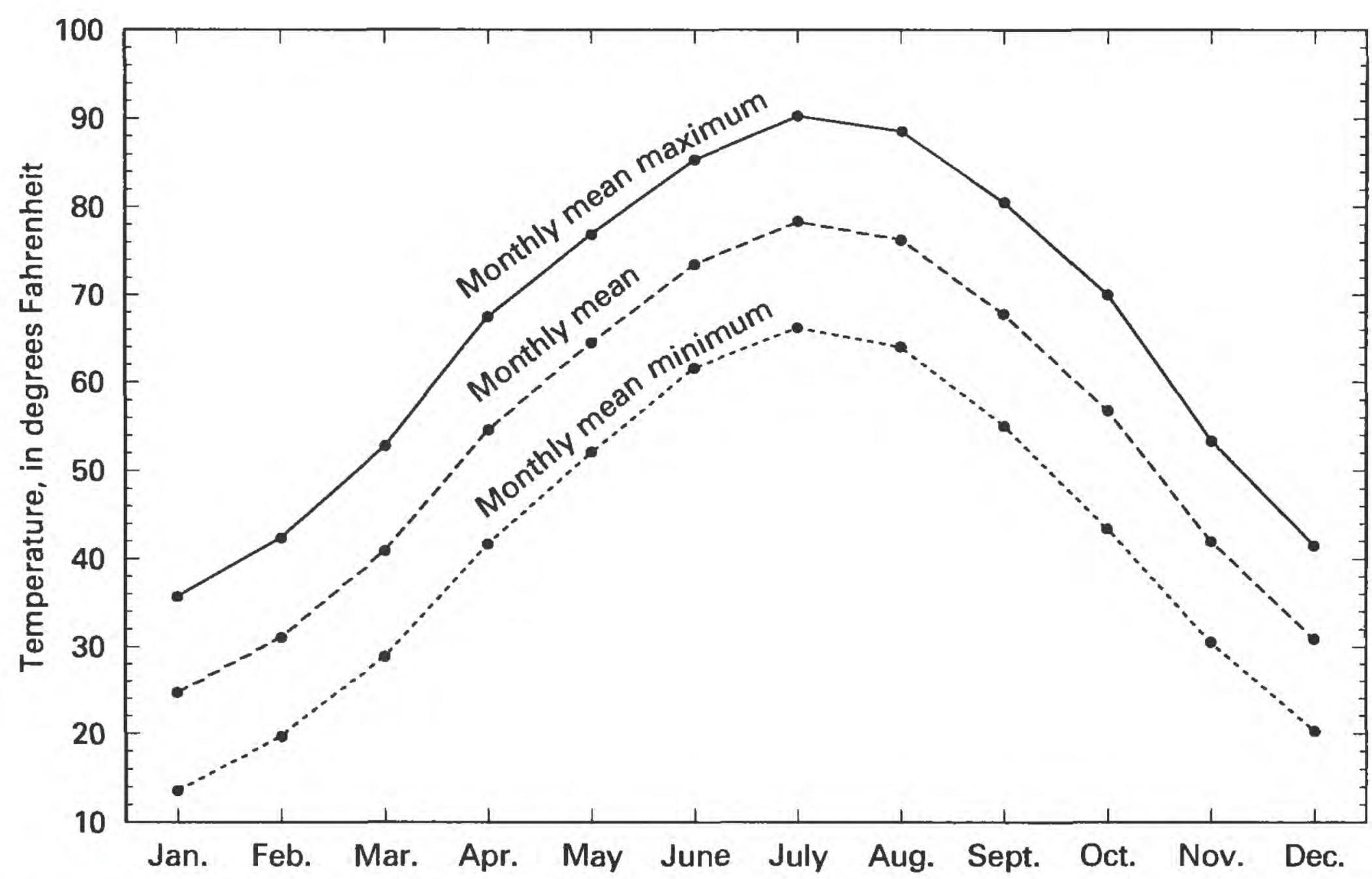

Figure 9. Monthly mean maximum, mean, and mean minimum temperatures for Horton, Kansas, 1888-1991 (data from National Oceanic and Atmospheric Administration, 1992-94).

determined using the months of occurrence of the 7day low flow. Long-term trends in streamflow were determined using moving averages of monthly streamflows.

Ground-water availability was defined by describing aquifer location, extent, geometry, geology, and potentiometric surfaces. Hydraulic properties of the aquifers were estimated using published results of aquifer tests. Where water-level data were available, hydrograph comparison and analysis afforded a method to evaluate long-term effects of withdrawals from the aquifers. Results of previous ground-waterflow modeling of a segment of the Kansas River Valley illustrate the effects of proposed increased withdrawals from the Kansas River Valley aquifer.

Each data-collection site in this report, whether a stream site or well, has been assigned a unique identification number. The number usually is assigned when a site is first established and is retained for that site indefinitely. The systems used by the USGS to assign identification numbers for surface-water sites and for ground-water well sites differ, but both are based on geographic location. The downstream-order system is used for surface-water sites, and the latitude-longitude and local well-numbering systems are used for wells.
Since October 1, 1950, the order of listing surfacewater site records in USGS reports is in a downstream direction along the main stream. All sites on a tributary entering upstream from a main-stream site are listed before that site. A site on a tributary that enters between two main-stream sites is listed between them. A similar order is followed in listing sites on first rank, second rank, and other ranks of tributaries.

The site-identification number for a surface-water site is assigned according to the downstream order. The complete eight-digit number for each site, such as 06815000 , which appears to the left of the site name in table 4 of this report, includes the two-digit part number " 06 " plus the six-digit downstream-order number "815000." The part number designates the major river basin; part "06" is the Missouri River Basin.

The identification number for miscellaneous surface-water sites and for wells is a 15-character number containing no blanks or alphabetic characters. It is used primarily as an internal control number.

Although the site-identification number is formed initially from the latitude and longitude of a point believed to represent the location of the site, the number is an identifier and not a locator. It is used as a pure 


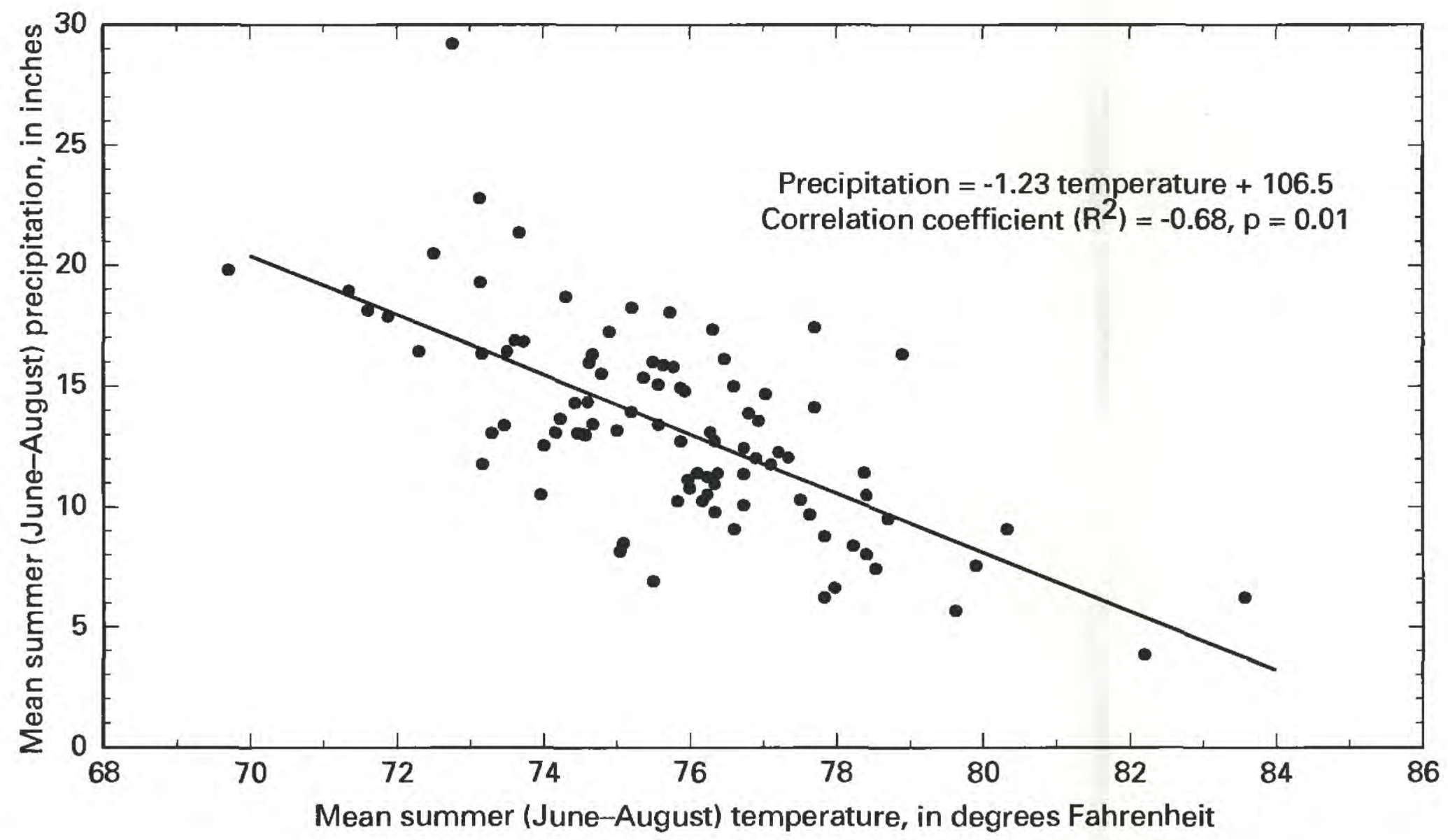

Figure 10. Relation of mean summer precipitation to mean summer temperatures in the Northeast Kansas Climatic Region (data from National Oceanic and Atmospheric Administration, 1992-94).

number and has no locational significance (Mathey, 1990, p. 2-10).

Local well numbers are assigned according to a modification of the Bureau of Land Management's system of land subdivision. In this system (fig. 12), the first set of digits in the well number refers to the township north (N) or south (S) of the Kansas-Nebraska State line; the second set or refers to the range east (E) or west $(\mathrm{W})$ of the sixth principal meridian; and the third set refers to the section in which the well is located. The terminal letters refer to the 160 -acre, 40-acre, and 10-acre tracts within the section. The letters A, B, C, or D are assigned in a counterclockwise direction beginning in the northeast quadrant. The final two digits are sequence numbers beginning with 01. For example, local well number 05S 17E 18ADD 01 indicates the first well located in the southeast quarter of the southeast quarter of the northeast quarter of sec. 18, T. 5 S., R.17 E. (fig. 12).

Data from about 90 stream sites and 550 wells (Trombley and Kenny, 1992; Brewer and others, 1994) were used to describe water quality in the study area. This report presents areal characterization of water quality by drainage basin using summary statistics and graphical methods for: (1) $\mathrm{pH}$, (2) major ion concentrations, (calcium, magnesium, potassium, sodium, chloride, and sulfate), (3) dissolved-solids concentrations, (4) major metals concentrations (iron and manganese), (5) nutrient concentrations (nitrite plus nitrate as nitrogen and orthophosphate as phosphorus), (6) herbicide concentrations (atrazine), (7) bacteria concentrations (fecal coliform and fecal streptococcus), and (8) suspended-sediment concentrations. Other water-quality data are available in Brewer and others (1994); however, there were not enough data to facilitate adequate analysis in this report.

Standard boxplots were used to provide an overview of the concentration distributions within each of the four major drainage basins. Boxplots are a useful method for comparing the statistical characteristics of several data sets (Helsel and Hirsch, 1992, p. 24-26). Median values, the center line on the boxplot, represent approximate overall water quality within each basin. The length of the box, the distance between the 75 th and 25th percentiles of the data, gives an indication of the variation in values. Relative skewness of the data is indicated by the difference between the sizes of the box parts and the lengths of the "whiskers" above and below the box. The presence or absence of unusual values is indicated by plotting extreme values individually. "Outside" values, which are plotted as " $x$ ", are present in less than 1 of 100 values that are 


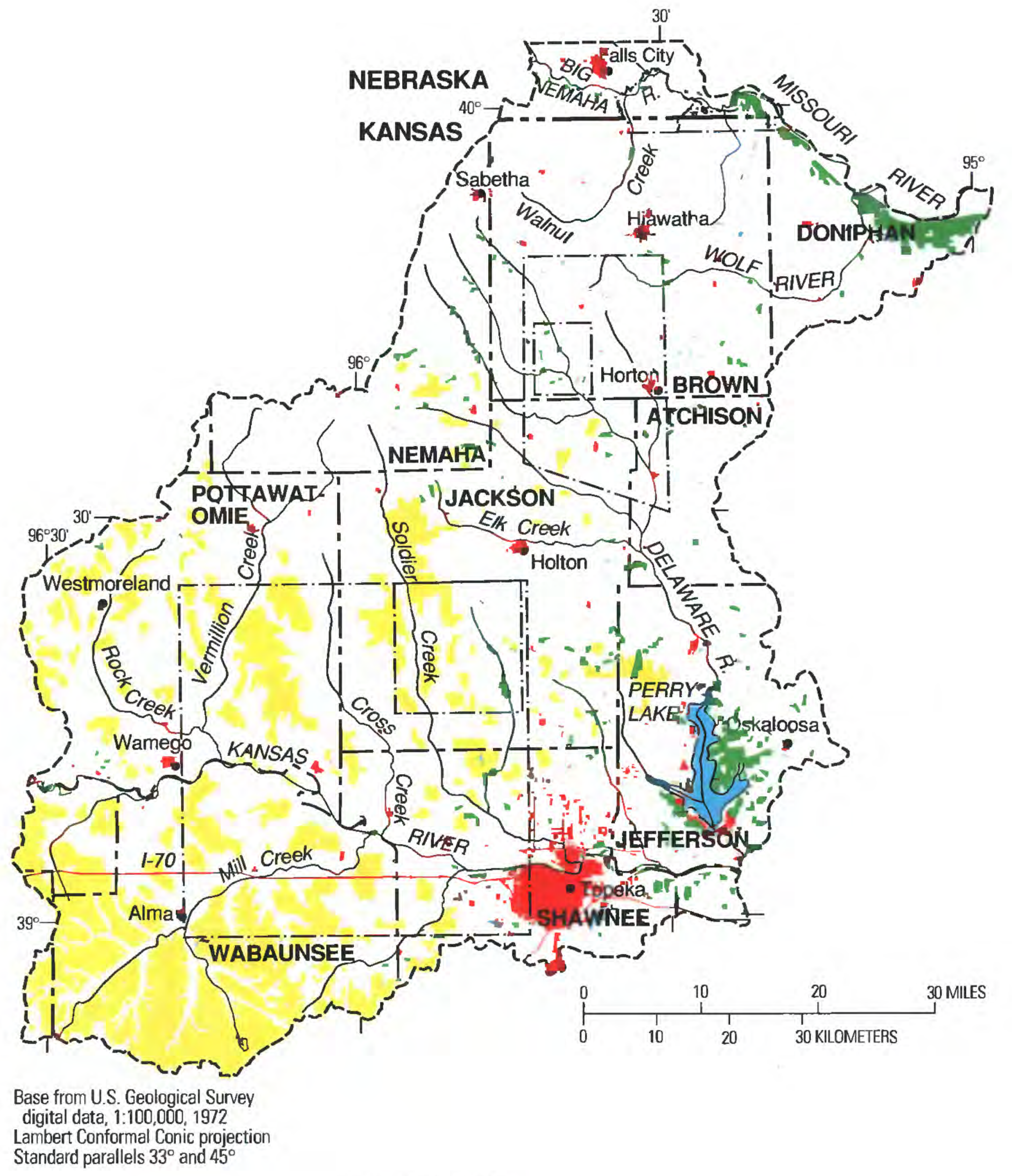

EXPLANATION

\begin{tabular}{|c|}
\hline Urban or built-up area \\
\hline Agricultural land \\
\hline Rangeland \\
\hline Forestland \\
\hline Water \\
\hline
\end{tabular}

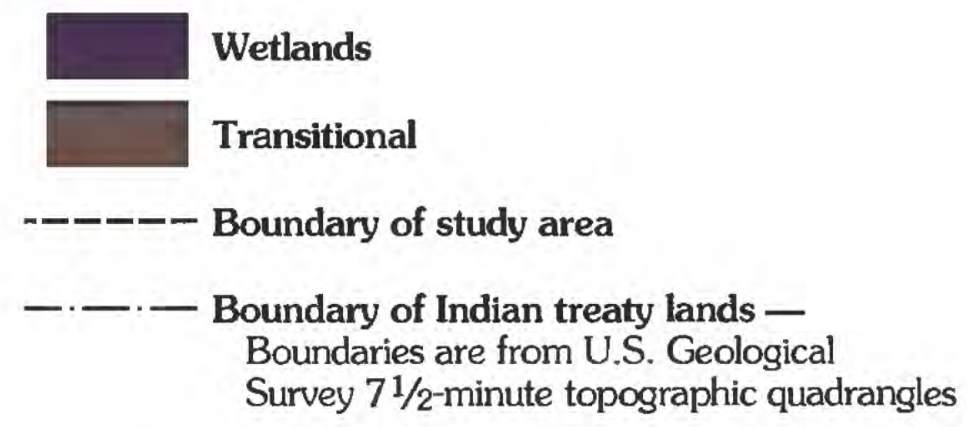

Figure 11. Present (1995) land cover and land use in study area. 


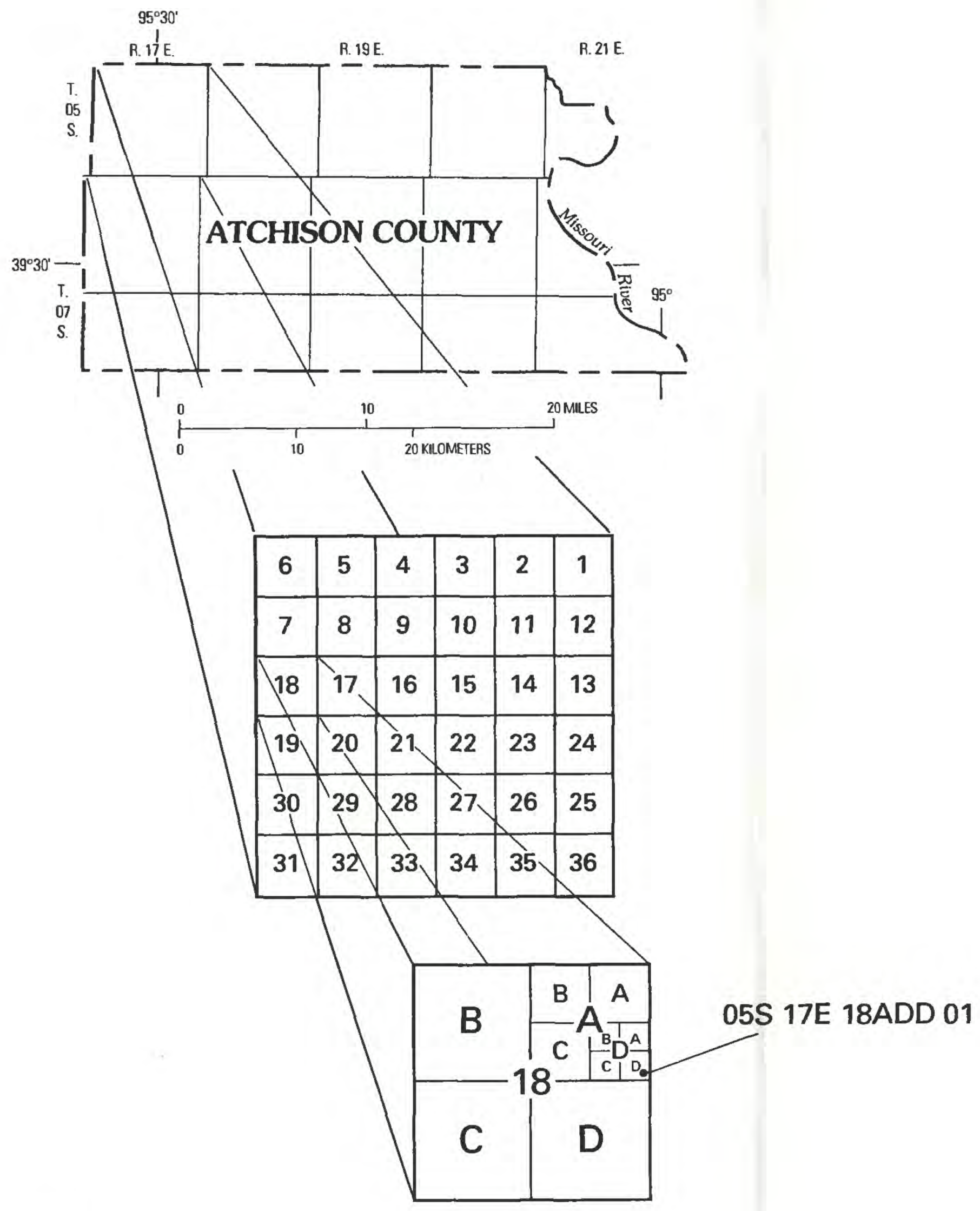

Figure 12. Local well-numbering system used in this report.

normally distributed. "Far outside" values, plotted as an "o" are present in less than 1 of 10,000 values that are normally distributed. The term "typical range" (interquartile range) is used throughout this report to indicate where one-half of the values lie, between the 75 th and 25th percentiles.

Boxplots illustrating areal distribution of waterquality constituents within the study area were calculated using one value for each site within the drainage basin to eliminate biasing by sites with a large number of analyses. For sites with one analysis, the value for that analysis was used. For sites with multiple analyses, the median value for that site was used. Waterquality trends through time were not evaluated because the analysis requires a minimum of about 10 years of incremental data. Very few sites meet these requirements; therefore, time trends throughout the study area could not be determined. 


\section{SURFACE-WATER AVAILABILITY}

The only plentiful supplies of surface water are located on and near the margins of the study area. As figure 13 shows, the Missouri River and the Kansas River have much larger mean annual streamflows than do other streams in and adjoining the study area. Relative to the most recent treaty lands, only the Iowa treaty land has direct access to large streamflow (the Missouri River). The Sac and Fox land borders the Big Nemaha River, which has medium streamflow relative to other streams in the study area. The most recent Kickapoo and Potawatomi treaty lands have access to streams having small mean streamflows.

\section{Variability, Seasonality, and Long-Term Trends}

\section{Variability}

Variability of streamflow is affected principally by variability of precipitation, by the amount of groundwater contribution (which has less variability than that of surface runoff), and by reservoirs if they are present. Information on variability of streamflow at 18 gaging stations in the study area has been compiled and illustrated for annual mean values and for daily values in Brewer and others (1994, figs. 5 and 6). Daily values varied from zero to more than $5,000 \mathrm{ft}^{3} / \mathrm{s}$ for many of the small streams and from less than 1,000 to more than $50,000 \mathrm{ft}^{3} / \mathrm{s}$ for the Kansas River (Brewer and others, 1994, fig. 6). Annual mean values showed as much as a 50 -fold variation for small streams and a 22-fold variation for the Kansas River (calculated from figure 5 of Brewer and others, 1994). These degrees of variability may have a great effect on planning and design for surface-water supplies.

\section{Seasonality}

Seasonal patterns of streamflow were examined for a typical small stream in the study area, Soldier Creek near Topeka, Kansas (site 15, fig. 13). Sixty years of record, 1930-32 and 1936-92, were used to determine the seasonal patterns of mean streamflows and low flows. The largest monthly streamflows occurred in March through June, with 55 percent of the mean annual streamflow volume occurring during those 4 months (fig. 14). The smallest streamflow for 4 consecutive months was for November through February, with only 17 percent of the mean annual volume occurring during those 4 months. The smallest flow for 7 consecutive days in a year occurred most often in August, September, or October, with 59 percent of the occurrences during those 3 months. The least-frequent 7 -day low flow in 3 consecutive months was in April through June, with only 6 percent of the occurrences during those 3 months.

The typical seasonal distribution of streamflows indicates a pattern favorable for the short-term (less than 1 year) use of impoundments for water supply or low-flow augmentation; typically large flows in March through June could be impounded for use during August through October when natural flows typically are small. However, droughts of 2 or more consecutive years are common and would largely negate this advantage except for very small water-supply needs.

\section{Long-Term Trends}

Available records of streamflow in the study area are not adequate for study of time trends for more than a few decades. Records are completely inadequate for study of trends that may have resulted from the largest changes to have occurred in the area, those of land cover and land use before the 20th century.

The longest record of streamflow that includes runoff from the study area is for the streamflowgaging station on the Kansas River at DeSoto, Kansas (site 19, fig. 13). Although the station is outside the study area, it receives streamflow from much of the study area. In a previous report (Jordan, 1986, fig. 2), a graph showing 15-year moving averages of discharge (streamflow) at DeSoto for 1917-85 appeared to show an increasing trend.

Because the longest available records for streamflow in and near the study area are considerably shorter than the longest available records of precipitation, the use of an averaging period of 15 years for streamflow, compared with the 22 years used for precipitation at Leavenworth, Kansas, in this report, is justified. Soldier Creek near Topeka, Kansas, has a continuous record of streamflow within the study area since 1936 and has not been affected substantially by impoundments or diversions of flow. The annual mean streamflows for 1936-92 and the 15-year moving 


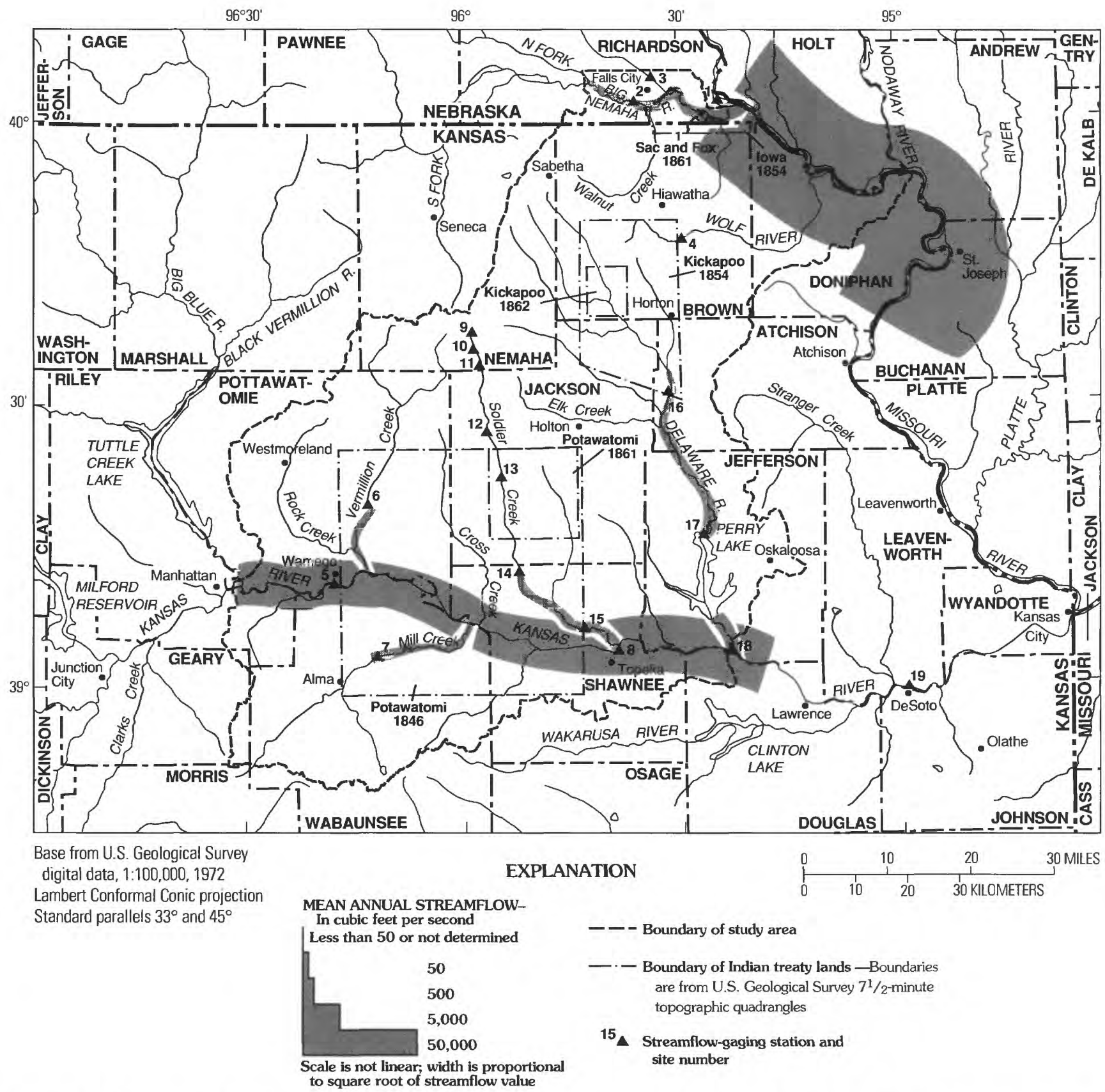

Figure 13. Comparative magnitude of mean annual streamflows in and near study area and location of streamflow-gaging stations referred to in this report.

average are shown in figure 15 . A notable feature of this illustration is the substantial variability of the annual streamflows from which the moving average was calculated. The moving average gives the appearance of a trend of larger flows during the later years. This apparent trend is affected by the fact that the record begins during a sequence of drought years and that another sequence of drought years occurred during the 1950's.
Because of the typically large variability of streamflow from year to year, information on barely detectable long-term trends may not be helpful for water-supply design consideration. As noted by Matalas 1990, p. 140),

"Trend in mean would need to be quite pronounced (say relative to the coefficient of variation of the mean) to override the uncertainty in design introduced by the variance." 


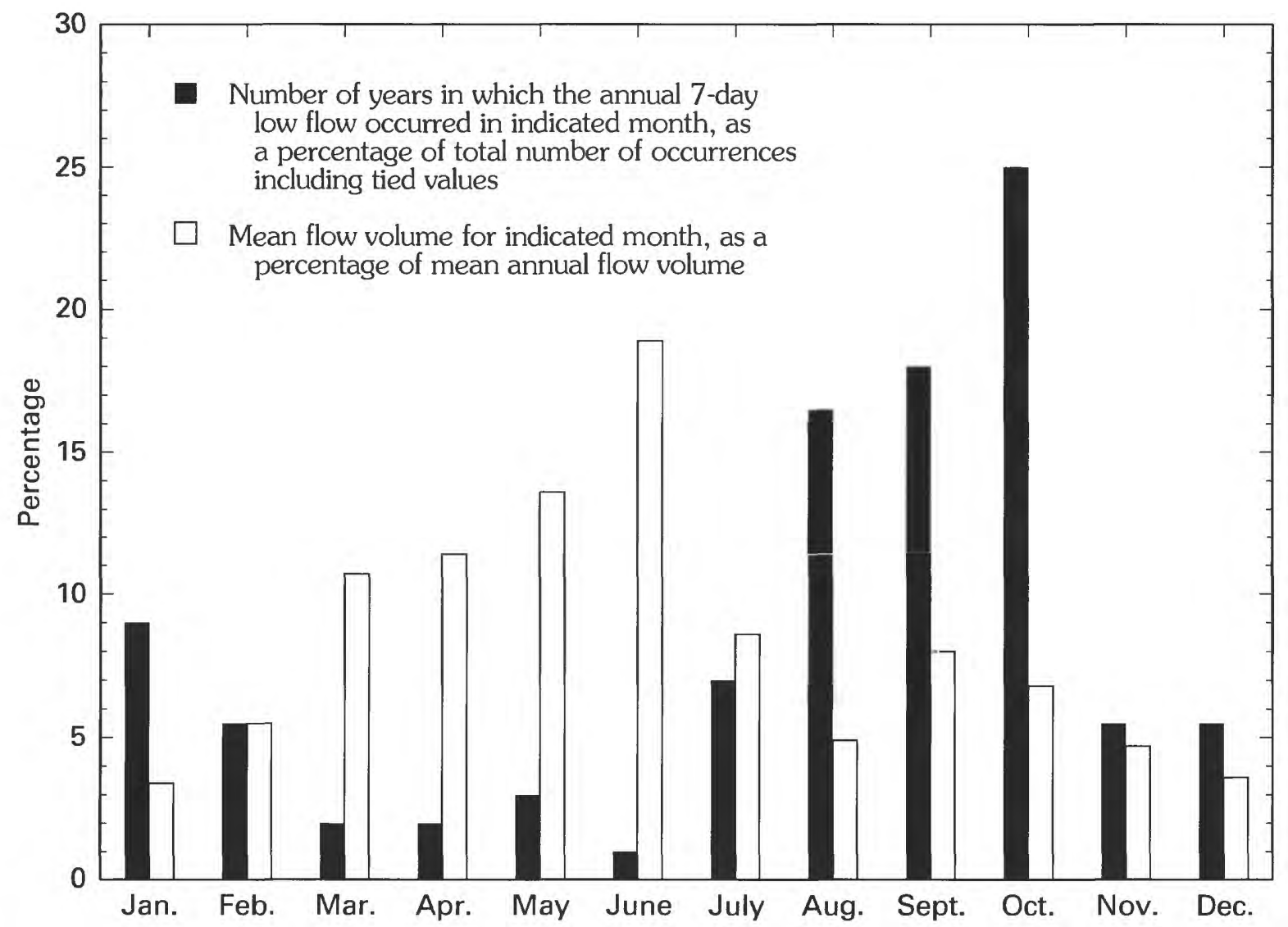

Figure 14. Seasonal distribution of 7-day low flows and monthly mean streamflows for Soldier Creek near Topeka, Kansas (site number 15, fig. 13), 1930-32 and 1936-92.

\section{Surface-Water Availability Without Impoundment}

Availability of surface water without impoundment may be evaluated by the occurrence frequency of extreme low flows lasting for short periods of time. Because public water-supply systems generally store a few days supply in standpipes, tanks, or towers, a practical measure of the availability of streamflow is the lowest mean streamflow for 3 or 7 consecutive days.

Table 3 shows 3-day, 7-day, and 30-day low flows for selected recurrence intervals at several streamflowgaging stations in the study area. For the Kansas and Missouri Rivers, each affected by several reservoirs and streamflow diversions, the values were calculated from streamflow records representing 1995 levels of storage and diversions.

For streams not affected by large reservoirs or diversions, even though they may have small watershed district structures and diversions, the low-flow values shown in table 3 are as determined by Jordan
(1983). Those determinations included results obtained by extending records less than 25 years using the relation of low flows to those at one or more nearby stations having additional records (Jordan, 1983, p. 9).

Information in table 3 also can be used for estimation of low-flow magnitudes for ungaged sites in either of two categories: (1) for an ungaged site that is between two of the stations on the same stream in table 3 (the Kansas River, Soldier Creek, or Delaware River), low-flow magnitudes can be estimated by interpolation; and (2) for other ungaged sites on one of the streams included in table 3 , the low-flow magnitude at a gaging station may be used as the estimate if the ungaged site is within a few miles of the gaging station and no major tributaries intervene. Consideration should be given to changes in geologic conditions affecting base flow, such as bedrock aquifers, glacial drift, or streamside alluvium. Interpolation or extrapolation of low-flow magnitudes will not be reliable if such conditions change appreciably between the ungaged site and the gaging station. 


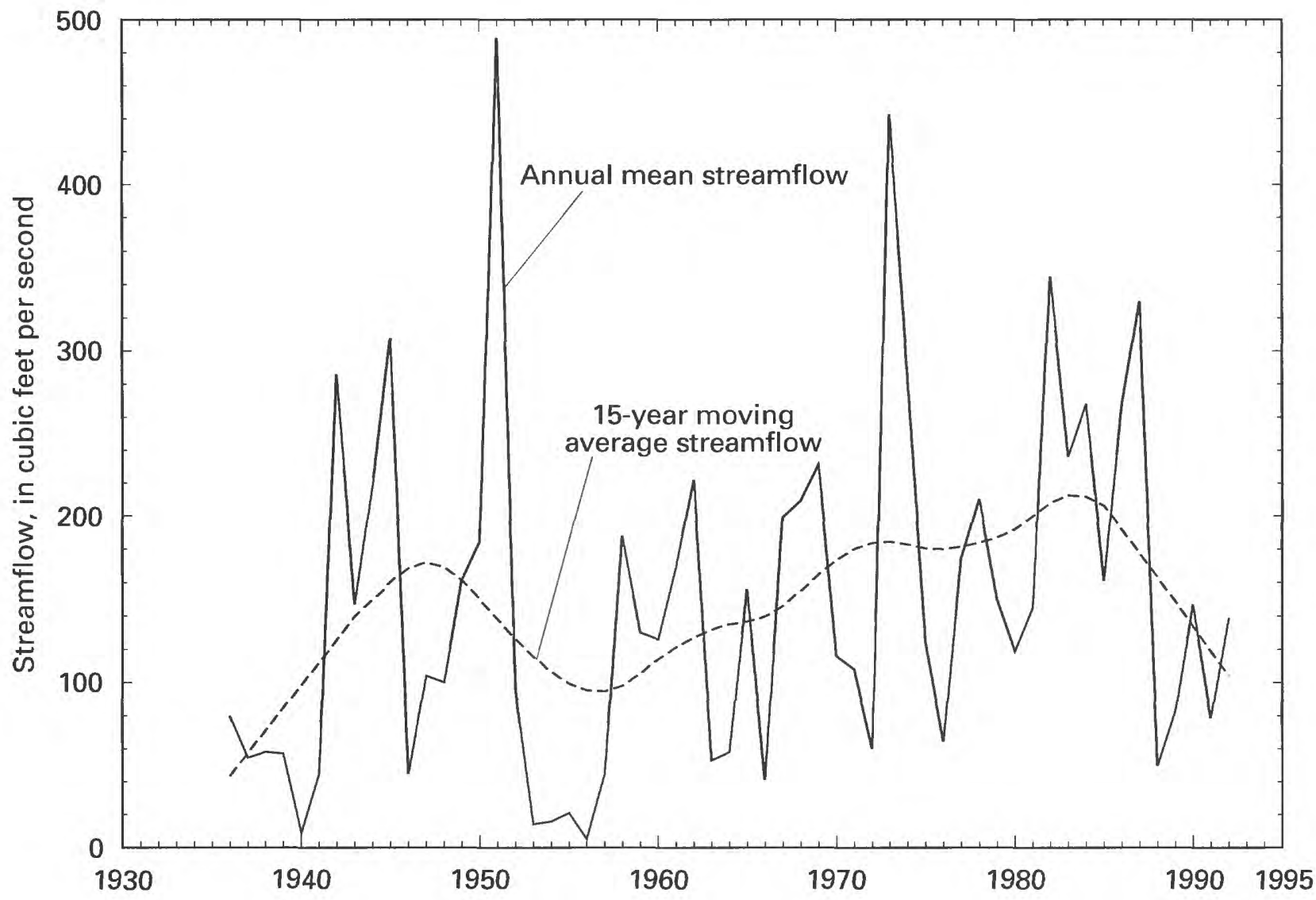

Figure 15. Annual mean streamflow and 15-year moving average streamflow for Soldier Creek near Topeka, Kansas (site number 15, fig. 13), 1936-92.

Legal and practical considerations prevent a user from withdrawing the entire flow of a stream for water supply. From the data in table 3, only a few streams may be judged to have flows adequate for substantial water-supply development. As an example, the 3-day low flow for a 20-year recurrence interval exceeds $1 \mathrm{ft}^{3} / \mathrm{s}$ (450 gal/min) only in the Missouri River, Big Nemaha River, Muddy Creek, and Kansas River. The fact that these streams are on the margins of the study area leaves little opportunity for developing surfacewater supplies without impoundments within the study area.

\section{Surface-Water Availability With Impoundment}

Storage requirements to sustain gross reservoir outflow at sites in the study area having drainage areas larger than $100 \mathrm{mi}^{2}$ can be estimated by a method reported by Furness (1962). However, construction of new surface-water impoundments within or adjacent to the study area for water supply probably is not practical for streams having drainage areas larger than about $300 \mathrm{mi}^{2}$ owing to topography and the cost factors related to topography. Potential sites for impoundments for drainage areas larger than $200 \mathrm{mi}^{2}$ on Vermillion Creek, Soldier Creek, and the Delaware River have been studied by Federal agencies for use in flood control and water supply (Missouri River Basin Commission, 1976, p. 123-153, 247-286); only the Delaware River impoundment (Perry Lake) was judged to be adequately cost effective, and it has been in use since 1969.

For stream sites having drainage areas smaller than $300 \mathrm{mi}^{2}$ in the study area, storage requirements can be estimated by a method reported by Carswell (1982). Draft-storage information is useful in making preliminary estimates for potential development and in comparing the development possibilities of different streams, although the draft estimates by the method cited do not account for the reduction of water supplies by evaporation, seepage, and sediment deposition. Regional draft-storage curves for 2-, 5-, and 


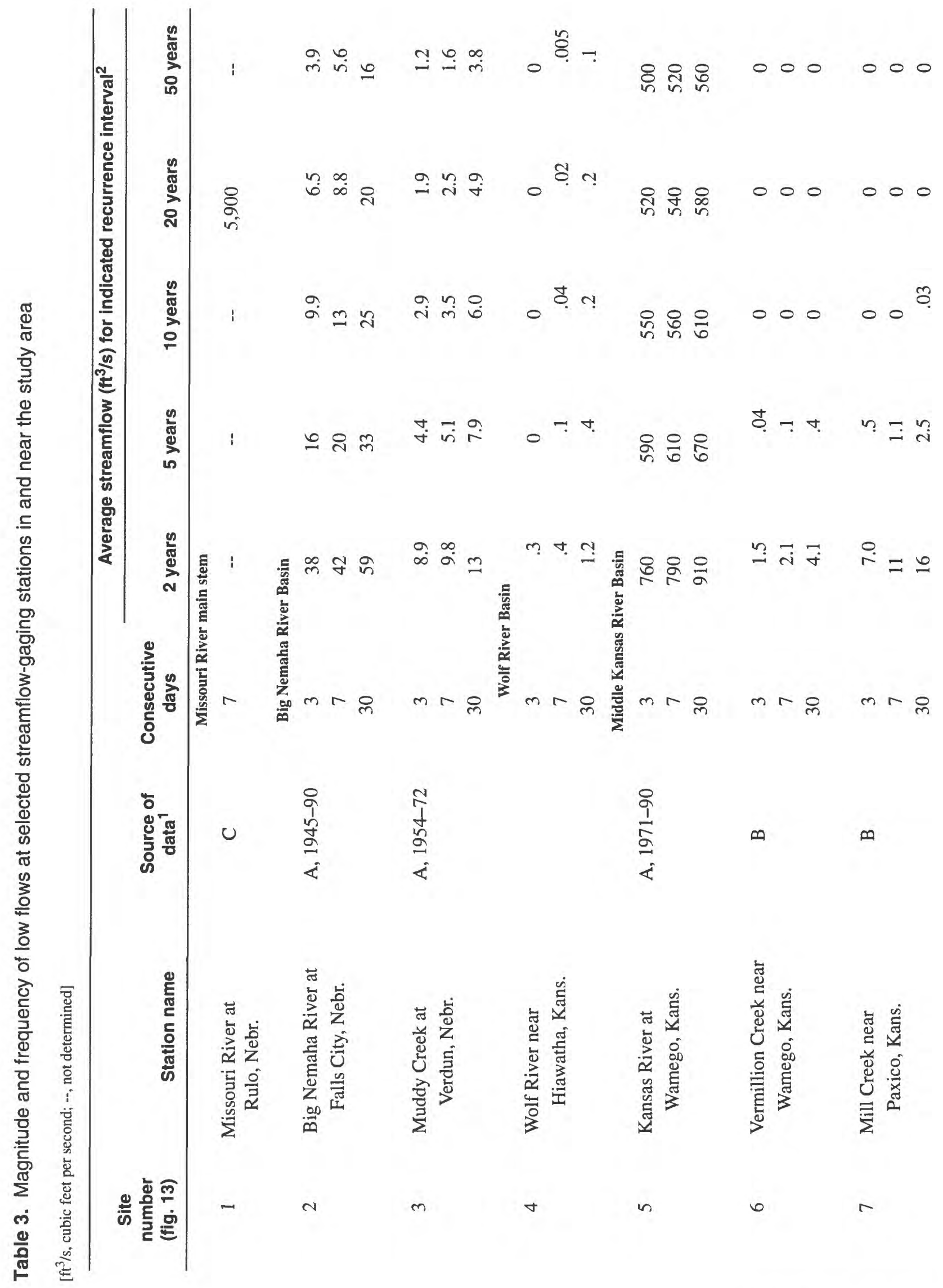




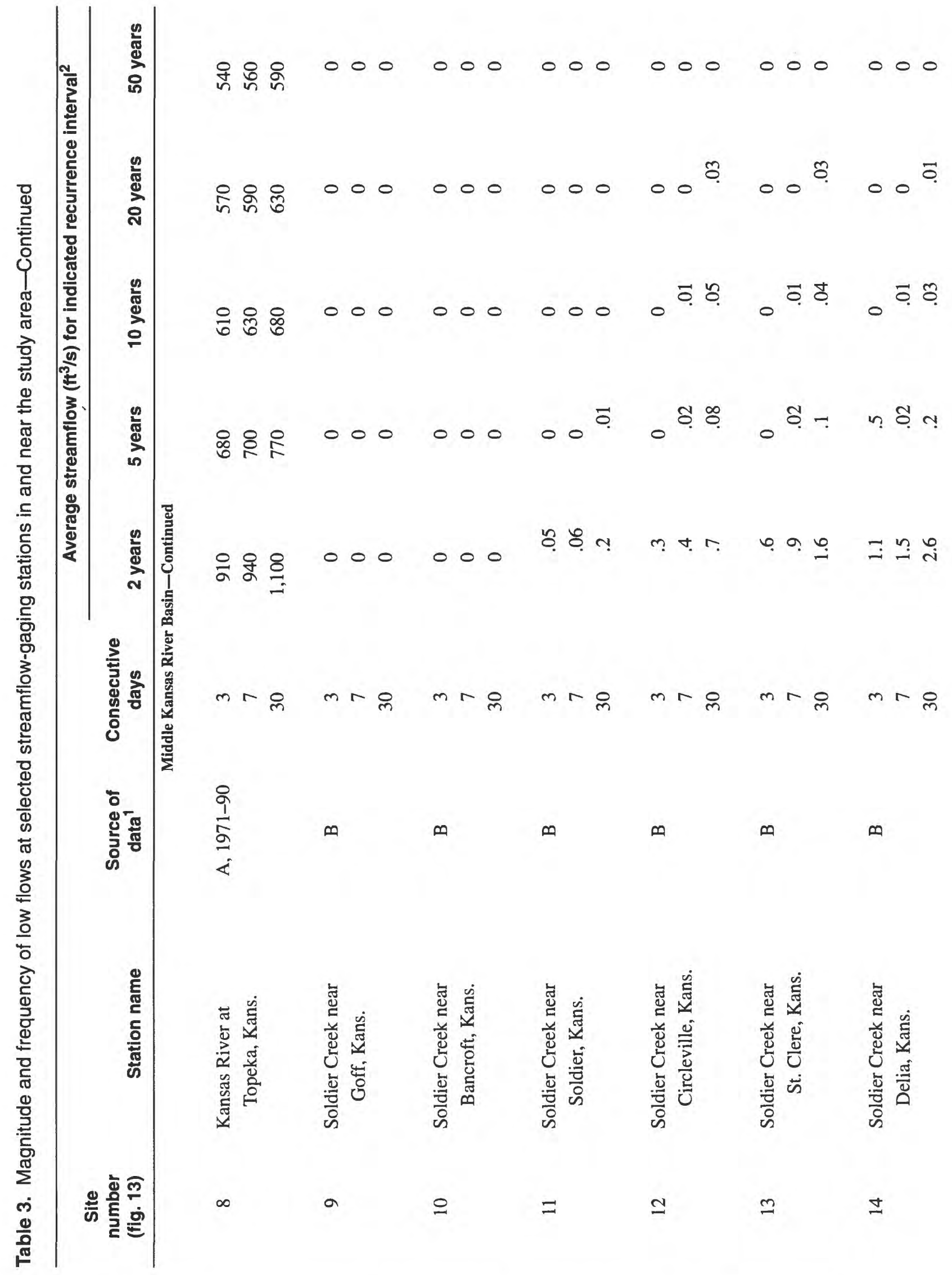




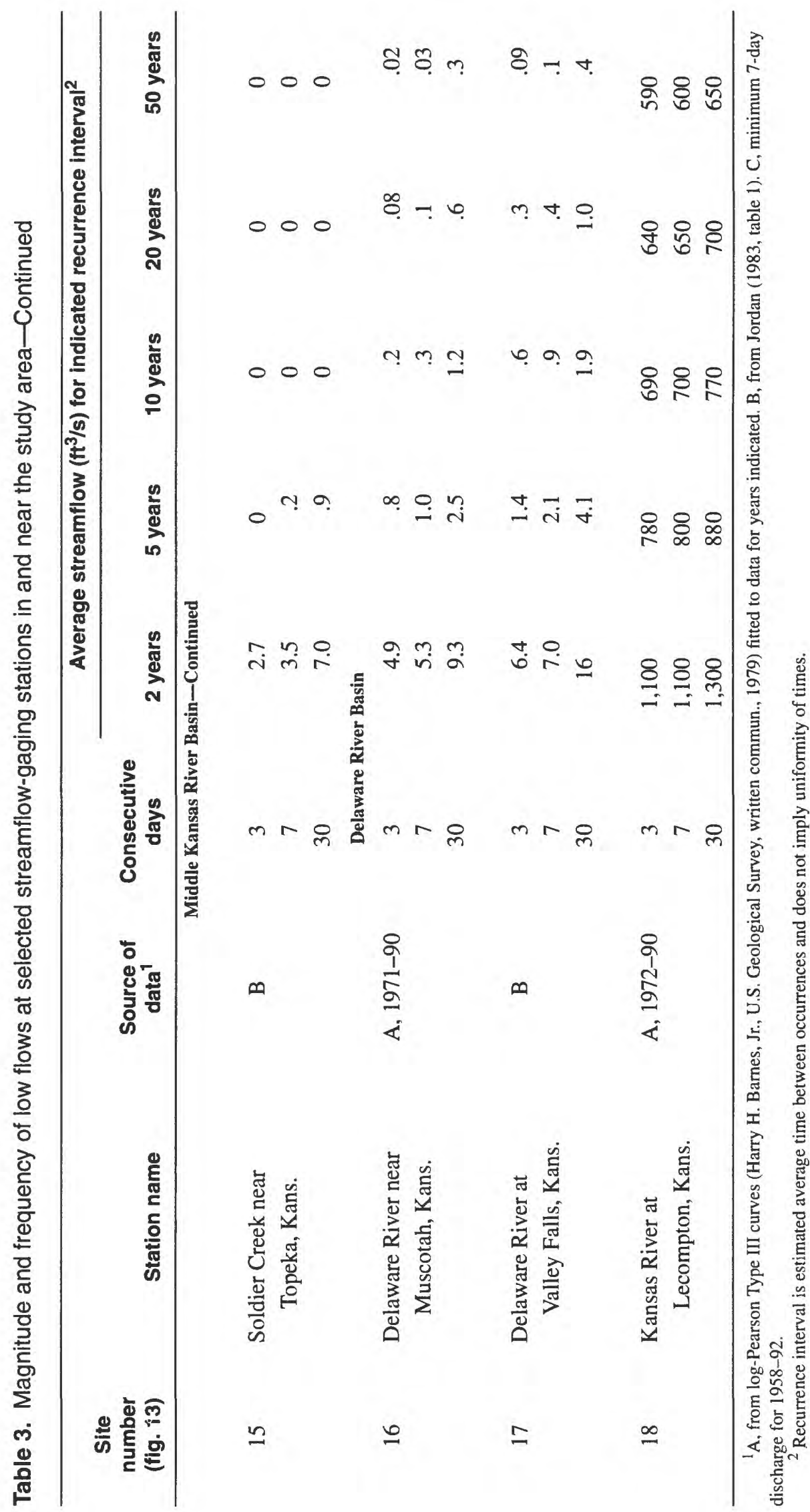


10-percent chances of draft-rate deficiency are presented by Carswell (1982) as plots of draft rate against mean annual runoff for selected levels of storage.

These curves can be used to estimate storage requirements at sites where long records of streamflow are not available.

Draft-storage curves for a 2-percent chance of draft-rate deficiency from Carswell's report (1982, fig. 4) are shown in figure 16; the range of mean annual runoff for the study area also is shown. Figure 16 can be used for calculating a first approximation of the draft rate available from storage at a site where the volume of storage available by impoundment has been determined from the topography of the site, the mean annual runoff has been estimated from figure 12 of Carswell (1982), and the land area draining to the site has been determined from a topographic map. For example, suppose a site being evaluated has mean annual runoff of 5.0 in., the area draining to the site is $40 \mathrm{mi}^{2}$, and an impoundment at the site could store 4,000 acre-ft. That volume of storage is 100 acre- $\mathrm{ft} / \mathrm{mi}^{2}$, and in figure 16 mean annual runoff of $5.0 \mathrm{in}$. intersects storage of $100 \mathrm{acre}-\mathrm{ft} / \mathrm{mi}^{2}$ at a draft rate of $0.11\left(\mathrm{ft}^{3} / \mathrm{s}\right) / \mathrm{mi}^{2}$. Thus, a draft rate of approximately $4.4 \mathrm{ft}^{3} / \mathrm{s}$ could be developed from the $40 \mathrm{mi}^{2}$ of drainage area, with a 2 -percent chance of deficiency. Figure 16 is the starting point from which draft-storage relations can be estimated for other chances of deficiency and can be adjusted further for the effect of serial correlation of annual flows (Carswell, 1982, figs. 5-11, fig. 17).

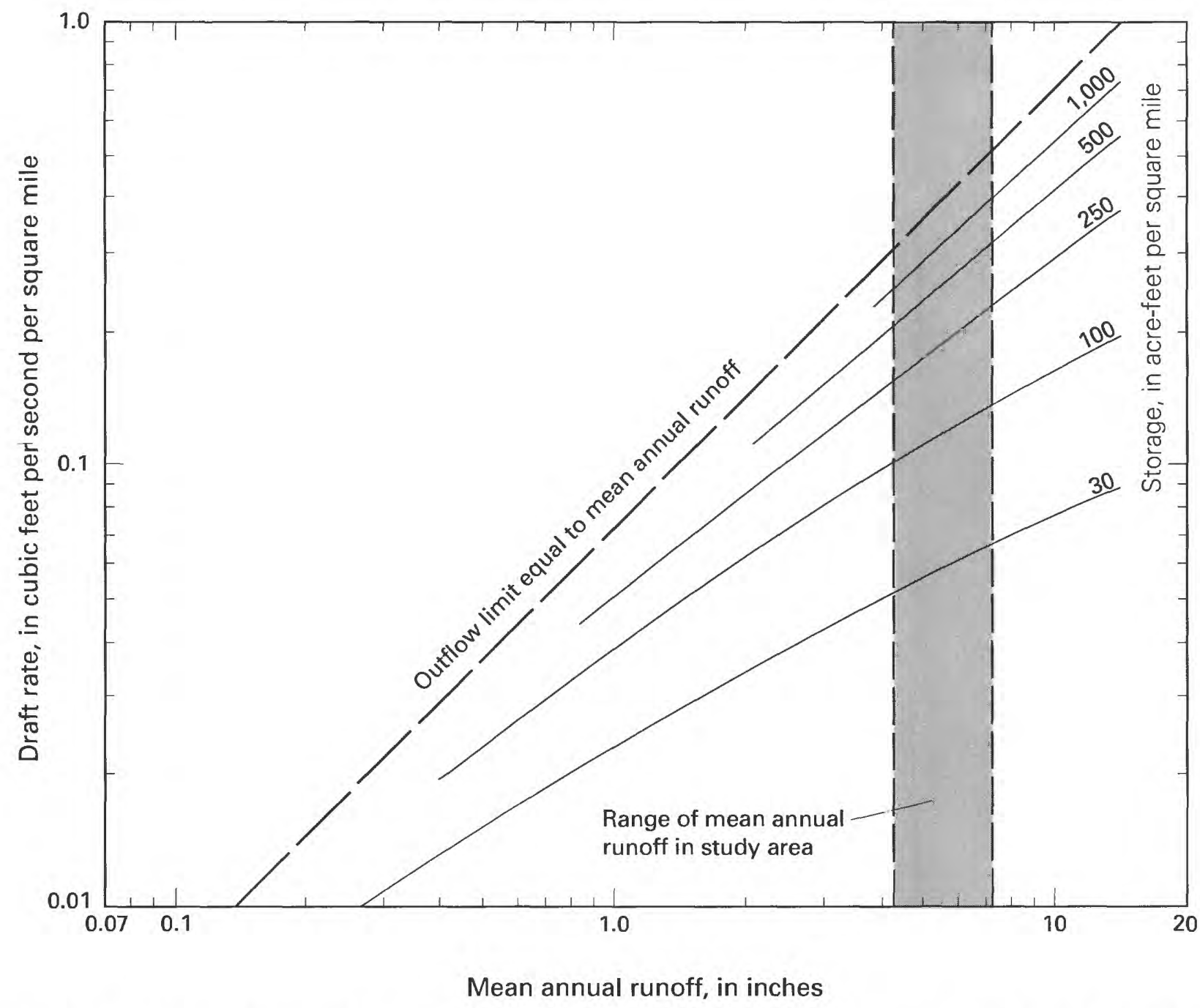

Figure 16. Draft-storage curves for 2-percent chance of draft-rate deficiency in study area (modified from Carswell, 1982, fig. 4). 


\section{GROUND-WATER AVAILABILITY}

The availability of ground water can be considered in two categories on the basis of well capacities. In this study, major aquifers are those that are capable of sustaining pumping rates of more than $300 \mathrm{gal} / \mathrm{min}$ to individual wells, such as those required for irrigation, large industrial, or municipal uses. Conversely, minor aquifers are those capable of sustaining pumping rates of less than $300 \mathrm{gal} / \mathrm{min}$. The minor aquifers can be divided further into those that yield less than $50 \mathrm{gal} / \mathrm{min}$ to individual wells (enough to sustain domestic, farm, and stock uses) and those capable of yielding from 50 to $300 \mathrm{gal} / \mathrm{min}$ to wells (such as those required by small industries, towns, and rural water districts).

Both the major and minor aquifers are important for different reasons. Although the major aquifers provide large yields to wells, they are limited in areal extent, namely only along the Kansas River and Missouri River Valleys. The minor aquifers, although capable of only small yields to wells, are important because at least one of the four minor aquifer types are available nearly everywhere in the study area for those users that require small but reliable amounts of water.

\section{Major Aquifers}

Only two major aquifers occur in the study area-the Kansas River Valley alluvial aquifer and the Missouri River Valley alluvial aquifer. The Kansas River Valley alluvial aquifer is used extensively for irrigation as well as for industrial and municipal purposes, especially near population centers, but the Missouri River Valley alluvial aquifer is not used extensively in the study area.

\section{Kansas River Valley Alluvial Aquifer}

The Kansas River Valley alluvial aquifer, which occurs along the flood plain and terraces of the Kansas River near the southern part of the study area, offers great potential for large-capacity wells. The aquifer coincides with hydrologic soil group 311 (fig. 3), which occurs between the bluffs along the Kansas River. Variations in aquifer lithology, which consist of Quarternary-age sand, gravel, silt, and clay, directly affects water availability from the aquifer. Thicknesses of the saturated alluvial material generally range from less than $1 \mathrm{ft}$ near the valley edges to about $70 \mathrm{ft}$ in the deepest part of the buried channel (Wolf and Helgesen, 1993).

Reported well yields from the alluvial aquifer in Shawnee County, Kansas, were as large as 2,500 gal/min (J.E. Denne and others, Kansas Geological Survey, written commun., 1991). According to Fader (1974), well yields greater than $1,000 \mathrm{gal} / \mathrm{min}$ are common in areas of more than $40 \mathrm{ft}$ of saturated thickness. Well yields range from 300 to $1,000 \mathrm{gal} / \mathrm{min}$ where saturated thickness is 20 to $40 \mathrm{ft}$, and yields as much as $500 \mathrm{gal} / \mathrm{min}$ are locally possible even where saturated thickness is less than $20 \mathrm{ft}$.

The quantity of water that the aquifer will yield depends on the properties of the alluvial material; Fader (1974) reported results of 18 aquifer tests in the Kansas River alluvial aquifer from Riley County to Wyandotte County, Kansas. Transmissivities (a measure of the capacity of an aquifer to transmit water) ranged from 5,300 to $48,000 \mathrm{ft}^{2} / \mathrm{d}$. Storage coefficients (the volume of water that an aquifer releases from or takes into storage per unit of aquifer surface area per unit change in hydraulic head) ranged from 0.0005 to 0.20 . Transmissivities reported from aquifer tests in the Kansas River alluvial aquifer from Shawnee to Wyandotte Counties ranged from 6,700 to $80,200 \mathrm{ft}^{2} / \mathrm{d}$ (J.E. Denne and others, Kansas Geological Survey, written commun., 1991). Transmissivities from aquifer tests using various pumping rates and durations for wells in the alluvial aquifer at an industrial facility in Topeka ranged from 46,800 to $89,600 \mathrm{ft}^{2} / \mathrm{d}$; the storage coefficient was 0.03 (J.E. Denne and others, Kansas Geological Survey, written commun., 1991).

Water-table maps of the Kansas River Valley alluvial aquifer have been published for the entire length of the valley from Junction City, Kansas, to the Missouri River for spring 1967 (Fader, 1974); from Wamego to just west of Topeka for spring 1956 (Beck, 1959); from Wamego to Topeka for spring 1987 (Wolf and Helgesen, 1993); and for the Topeka area for 1950 (Winslow and Nuzman, 1966). These maps can be used to assess spatial differences in aquifer water levels at a particular point in time and can be useful in determining the direction of ground-water flow and hydraulic gradients. The water-table map for spring 1967 (Fader, 1974) in the study area (fig. 17) shows water-level contours that bend upstream, indicating that the water-table gradient is toward the river and the alluvial aquifer was discharging to the Kansas River. For periods of drought when little or no recharge from precipitation occurs and the stream and 
aquifer water levels are lower, contours would cross the river farther upstream in the valley; conversely, for times of plentiful precipitation when ample recharge occurs, contours would cross the stream farther downstream.

Notable exceptions to the general slope of the water table toward the river occur as temporary reversals when the river rises rapidly due to runoff from precipitation or reservoir releases. These rapid river rises cause a temporary reversal of the hydraulic gradient toward the aquifer. Other reversals occur as persistent cones of depression in the water table around industrial pumping centers, such as in the Topeka area. Here, the direction of flow is locally

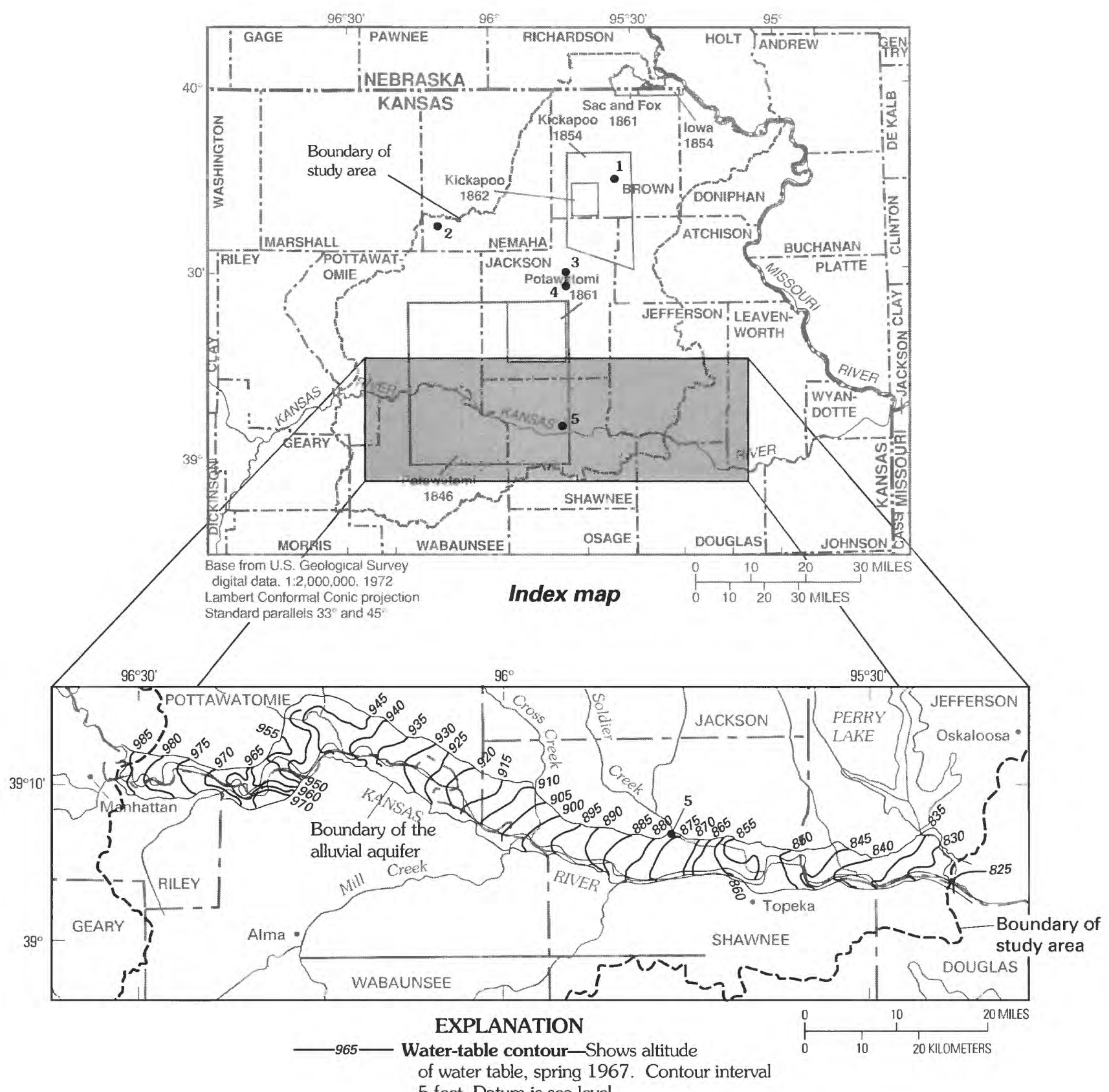

5 feet. Datum is sea level

- 5 Well and map number-Hydrographs shown in figures $18,20-21,23-24$

Figure 17. Altitude and configuration of water table in Kansas River Valley alluvial aquifer, spring 1967 (modified from Fader, 1974), and location of wells referred to in this report. 
reversed toward the nearly constant pumping of industrial wells. Where the cone of depression reaches the river, recharge from streamflow is induced by the gradient away from the river and may decrease normal streamflow (Wolf and Helgesen, 1993). Water levels in or near industrial and municipal wells fluctuate seasonally and even daily in direct response to withdrawals. Around areas with a large number of irrigation wells, some seasonal cones of depression in the water table develop during the growing season, but the water levels usually recover during the winter months.

Water-level measurements have been made periodically at various observation wells in the Kansas River Valley. Water-level data (on file with the USGS in Lawrence, Kansas) for the Kansas River Valley are available for more than 1,000 wells with one-time only measurements and 230 wells with multiple measurements. Of the 230 multiple-measurement wells, there are 43 with 4 years or more of record in the Wamego-Topeka area (Wolf and Helgesen, 1993). When plotted as hydrographs (water levels versus time), these measurements are useful to assess temporal differences in water levels during their period of record at a particular location in the aquifer.
Inspection of the hydrographs for wells completed in the Kansas River Valley alluvial aquifer indicates that for the available periods of record (since the early 1950 's) water levels have fluctuated cyclically in response to cyclical patterns of precipitation. Water levels generally rose in response to spring snowmelt or rainfall and to large summer rainfalls that exceeded soil-moisture deficiency, such as in July 1951. There do not appear to be substantial long-term declining water-level trends, which indicates that recharge to the alluvial aquifer approximates discharge from the aquifer, including well withdrawals.

A hydrograph (fig. 18) for a well completed in the Kansas River Valley alluvial aquifer and located about 1 mi west of Topeka, Kansas, was drawn from 2,041 water levels read every 5 th day from water-level recorder charts available for 1950-91. The hydrograph, considered representative of much of the aquifer, shows a general 2- to 8-ft annual cyclical recharge- and discharge-response pattern, but little or no long-term net change in water level. This hydrograph also marks the rapid rise in aquifer water levels to less than $10 \mathrm{ft}$ below land surface due to the 1951 flood, followed by the decline of water levels to

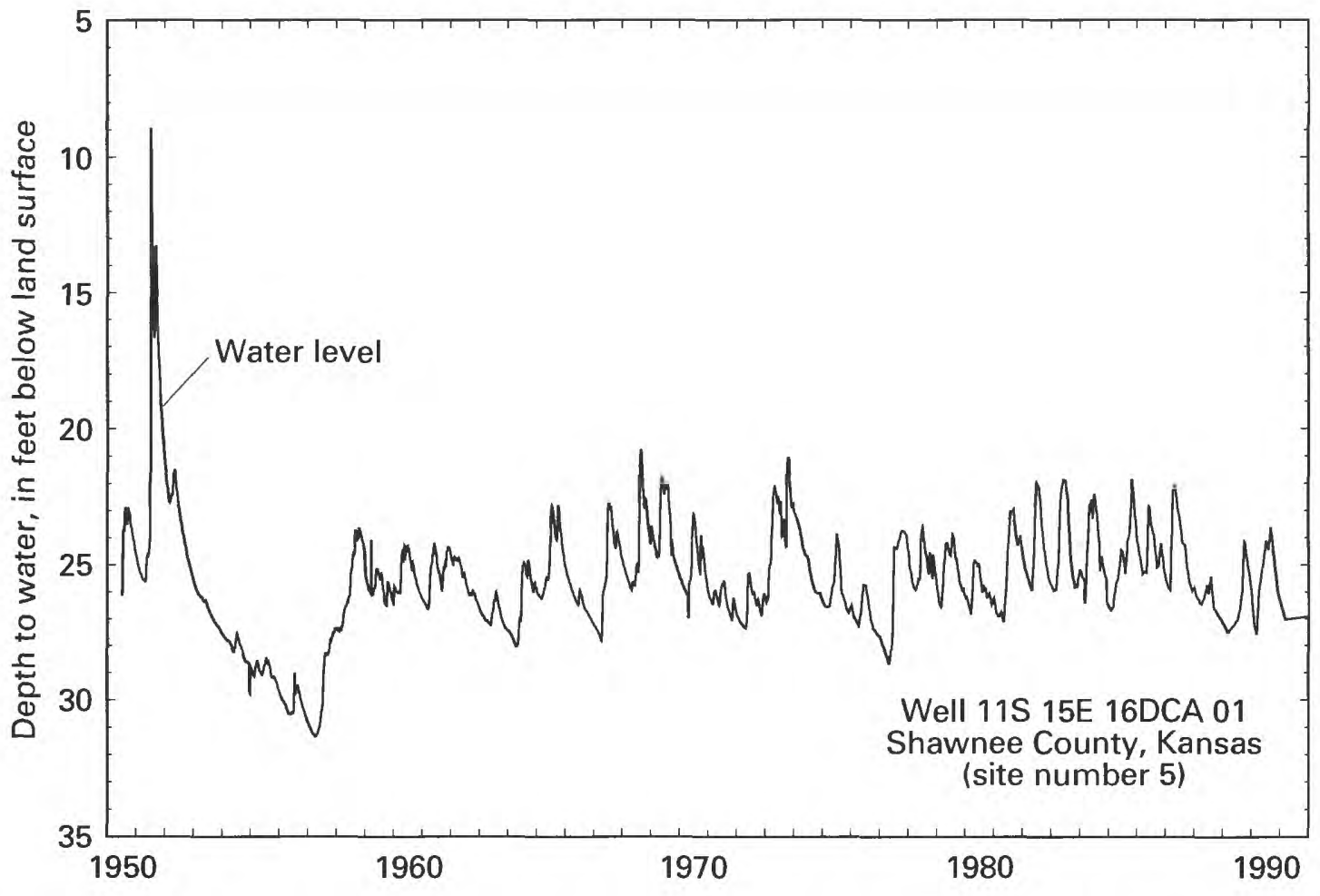

Figure 18. Water levels in well completed in the Kansas River Valley alluvial aquifer near Topeka, Kansas, 1950-91. Well location shown in figure 17. 
more than $30 \mathrm{ft}$ below land surface during the mid1950's drought.

To evaluate the Kansas River and associated alluvial aquifer system and the effects of ground-water development between Wamego and Topeka, Wolf and Helgesen (1993) used a finite-element computer model to simulate transient flow and water-level conditions for the 40-year period, 1948-87, and to implement thirteen 8-year simulations of below-average, near-average, and above-average streamflow and precipitation coupled with various hypothetical pumping options. Model results show average simulated waterlevel rises of about 2 to $4 \mathrm{ft}$ for above-average streamflow and precipitation conditions, declines of about 2 to $4 \mathrm{ft}$ for near-average conditions, and declines of about 6 to $10 \mathrm{ft}$ for below-average conditions.

The simulation of below-average streamflow and precipitation conditions was the basis for simulated 10-day upstream reservoir releases of 50,100 , and $500 \mathrm{ft}^{3} / \mathrm{s}$ during severe drought conditions. Model results indicated that on the first day of simulated reservoir releases under these conditions the river would be a losing stream (flow from the river to the aquifer) along most of its length. The simulations show that 1.8 percent of the water released was lost to the aquifer on the first day, about 1.6 percent was lost on the 5 th day, and about 1.2 percent was lost on the 10th day (Wolf and Helgesen, 1993).

\section{Missouri River Valley Alluvial Aquifer}

The Missouri River Valley alluvial aquifer, which is restricted to the flood plains and terraces along the Missouri River, also offers one of the greatest potentials in the study area for development of large-capacity wells because of the relatively large hydraulic conductivity (a measurement of how quickly water moves through the aquifer) of the sediments, abundant precipitation available for recharge, and the possibility of induced recharge from the Missouri River if wells are located near the river. The aquifer coincides with hydrologic soil group 211 (fig. 3), which occurs in the Missouri River Valley on the flood plain and terraces between the Missouri River and its bluffs. Water availability from the aquifer is affected directly by variations in aquifer lithology, which consists of Quarternary-age sand, gravel, silt, and clay. Thicknesses of the sediments range from zero at the valley walls to as much as $120 \mathrm{ft}$ in the deepest part of the buried channel (Emmett and Jeffery, 1969; Bayne, 1973). Aquifer-test results for wells in the alluvial aquifer in Doniphan, Atchison, and Leavenworth Counties, Kansas, indicated transmissivities that ranged from 26,800 to $80,400 \mathrm{ft}^{2} / \mathrm{d}$ and storage coefficients that ranged from 0.0004 to 0.001 (J.E. Denne and others, Kansas Geological Survey, written commun., 1991). Well yields as high as $3,000 \mathrm{gal} / \mathrm{min}$ may be obtained from coarse-grained sediments in the alluvium (J.E. Denne and others, Kansas Geological Survey, written commun., 1991); however, the largest reported well yields from the alluvial aquifer in Doniphan County, Kansas, ranged from 150 to $250 \mathrm{gal} / \mathrm{min}$.

Water levels have been published for the alluvial aquifer in the Missouri River Valley and principal tributary valleys in Doniphan County on the Kansas side for 1967 (Bayne, 1973). A water-level map also was published for the Missouri River Valley alluvial aquifer on the Missouri side between Kansas City, Missouri, and the Iowa border for January 1968 (Emmett and Jeffery, 1969). The part of these maps covering the study area (fig. 19) shows that water-level contours crossing the river bend upstream, indicating that the water-table gradient was toward the river and the alluvial aquifer discharged to the Missouri River. Hydrographs showing water-level fluctuations are not presented because multiple water-level measurements for wells in the Missouri River Valley alluvial aquifer in the study area were not available for this study.

The Missouri River Valley alluvial aquifer in the study area is not used extensively; however, potential problems exist for making use of the ample water supplies. Because much of the aquifer lies in the floodprone area of the flood plain, wells and pumps should be elevated or otherwise protected from flooding. Flood-insurance study maps depicting the areas subject to flooding are available from the Federal Emergency Management Agency (Kansas City, Missouri) for most cities and counties along the Missouri River.

\section{Minor Aquifers}

Minor aquifers that occur throughout the study area include small stream-valley alluvial aquifers, sand and gravel aquifers buried in glacial deposits, buried bedrock-valleys aquifers, and bedrock aquifers. 


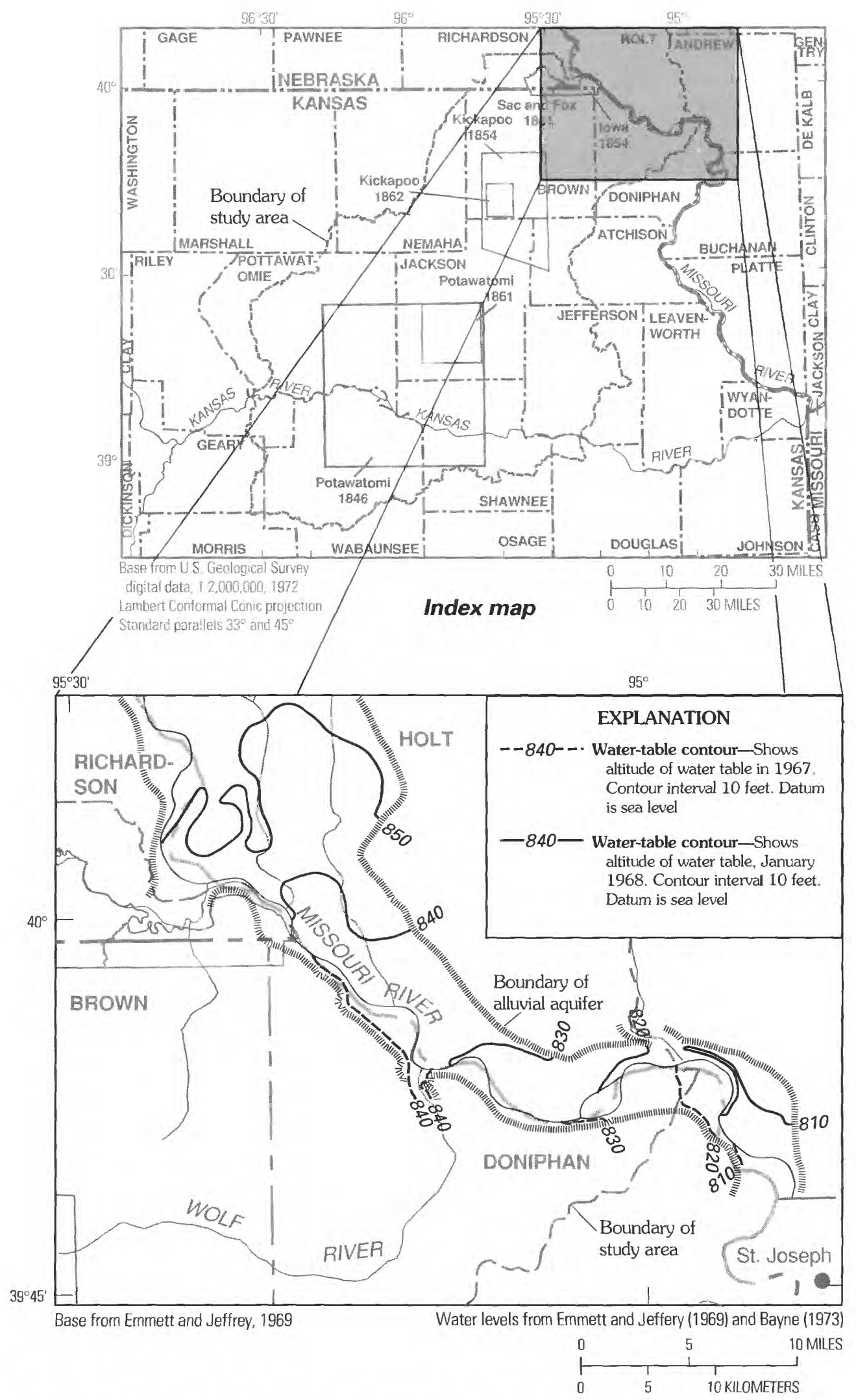

Figure 19. Altitude and configuration of water table in Missouri River Valley alluvial aquifer, 1967 and January 1968. 


\section{Small Stream-Valley Alluvial Aquifers}

In this report, small stream valleys refer to all stream valleys except the Kansas River and Missouri River Valleys. Although most of the small stream valleys in the study area generally contain clayey or silty alluvium, the alluvial deposits commonly have some coarser material near the bottom of the valley capable of yielding small water supplies (less than $300 \mathrm{gal} / \mathrm{min}$ ) to wells. Test drilling is necessary to delineate the deeper part of the valley where the coarser materials are commonly found. Figure 7 shows the location and extent of alluvial deposits but not their water-yielding capacity. Transmissivities determined from aquifer tests for wells 45 to $64 \mathrm{ft}$ in depth in the Delaware River alluvial aquifer ranged from 670 to $1,070 \mathrm{ft}^{2} / \mathrm{d}$, and storage coefficients were about 0.0004 (J.E. Denne and others, Kansas Geological Survey, written commun., 1991). A hydrograph (fig. 20) of water levels in an unused, 6-in. diameter, 17-ft deep well near Holton, Kansas, completed in the alluvial deposits of Elk Creek probably reflects fluctuations of water levels in the stream. The hydrograph shows a water-level fluctuation of about $4 \mathrm{ft}$ for the 35 periodic water-level measurements made from 1948-70.

\section{Sand and Gravel Aquifers Buried in Glacial Deposits}

Isolated deposits of sand and gravel of various but usually limited areal extent occur within the thick, mostly fine-grained glacial deposits in the study area (fig. 7) These isolated deposits are important as sources of water for individual households, farms, or stock wells and as supplies for some towns or rural water districts. Test-hole drilling is the most reliable method of locating these buried aquifers. Generally, the thicker the glacial deposits, the better the chance of finding a reliable ground-water source.

Recharge to the small isolated aquifers is very slow because of the small hydraulic conductivity of the surrounding clayey till deposits. Initial well yields may be large but may quickly decrease with sustained pumping as withdrawals exceed the very small recharge amounts coming through the surrounding till deposits. Thus, sustained pumping at relatively large rates can cause a steady decline in water levels of these aquifers. An example hydrograph (fig. 21) of local water-level declines illustrates the results of such a withdrawal and recharge relation. The 60 periodic water-level measurements made from 1972-93 are from an observation well located in Jackson County,

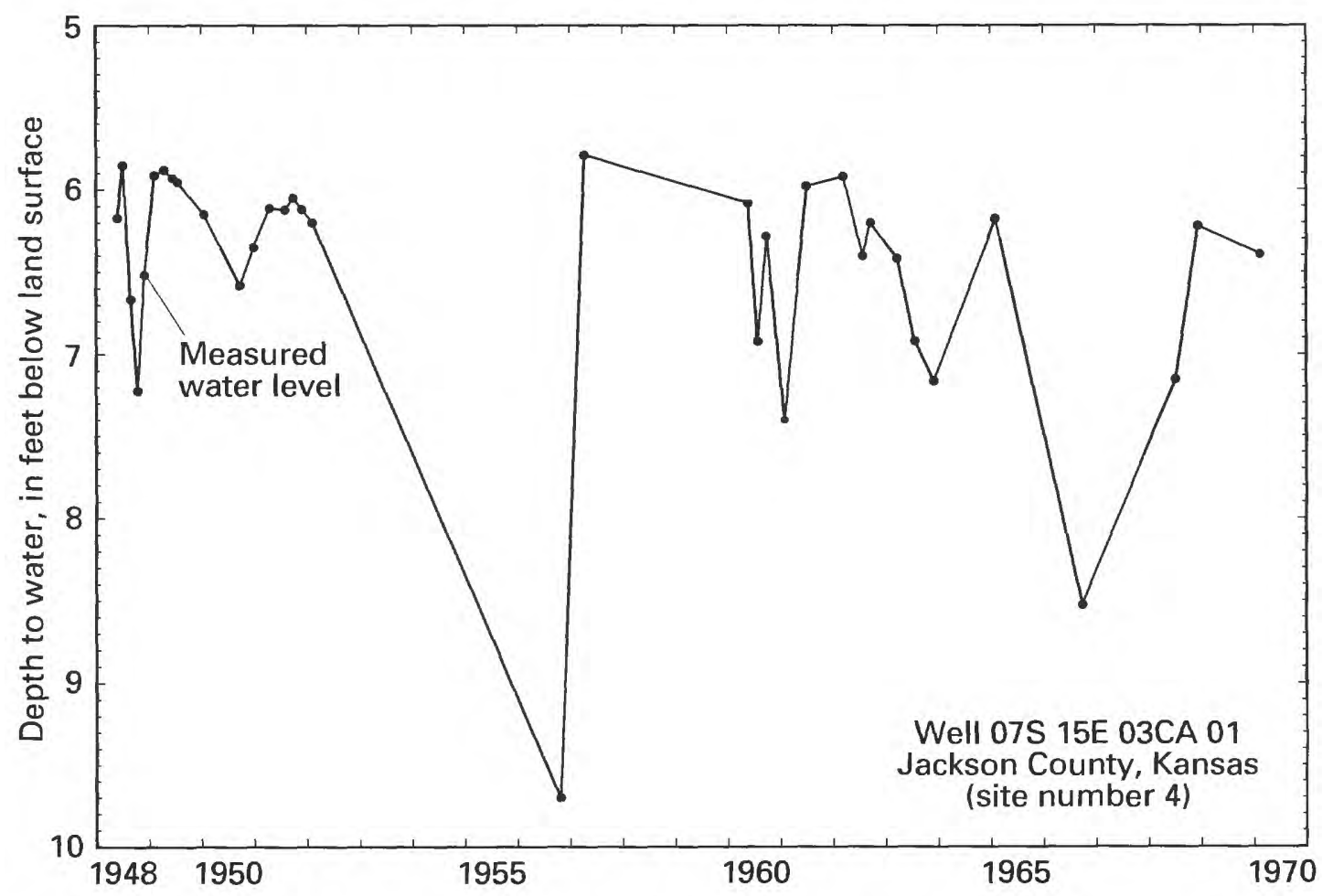

Figure 20. Water levels in well completed in a small stream-valley alluvial aquifer in Jackson County, Kansas, 1948-70. Well location shown in figure 17. 


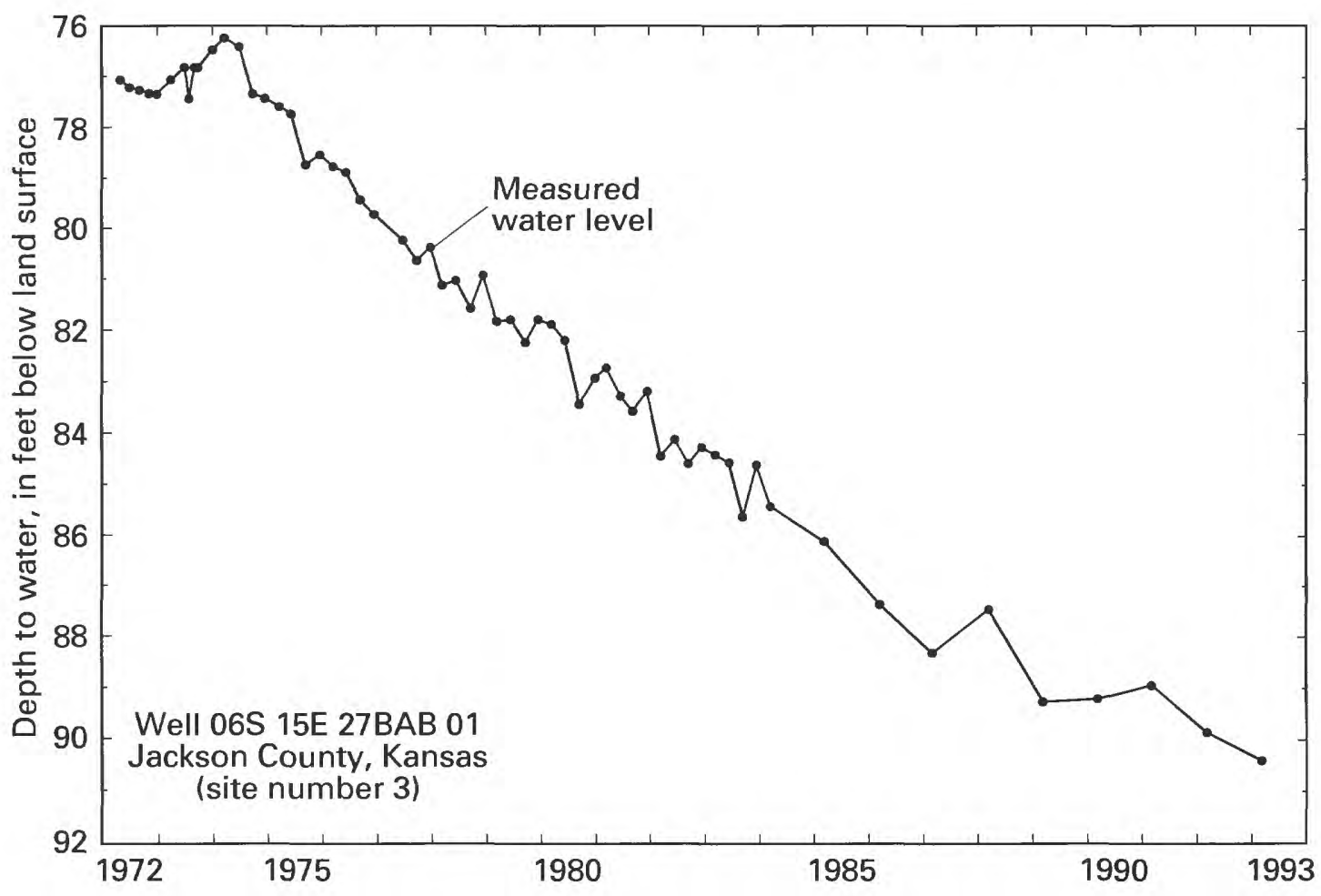

Figure 21. Water levels in well completed in a sand and gravel aquifer buried in glacial deposits in Jackson County, Kansas, 1972-93. Well location shown in figure 17.

Kansas, near a rural water district well field of three public-supply wells. In addition to small periodic or seasonal fluctuations, the hydrograph shows a generalized trend of water-level decline totaling about $14 \mathrm{ft}$ from 1972 to 1993 (averaging about $0.7 \mathrm{ft} / \mathrm{yr}$ ).

\section{Buried Bedrock-Valley Aquifers}

Buried sand and gravel deposits present in preglacial bedrock valleys are referred to in this report as buried bedrock-valley aquifers. Preglacial valleys in the study area (fig. 22) were mapped by Dreeszen and Burchett (1971). One major buried valley, which trends eastward across Nemaha, Jackson, and Atchison Counties, Kansas (fig. 22), may be as much as $3 \mathrm{mi}$ wide, $400 \mathrm{ft}$ deep, and as much as $75 \mathrm{mi}$ long (J.E. Denne and others, Kansas Geological Survey, written commun., 1991). Tributary valleys join the main stem of the major buried valley to form a typical dendritic drainage pattern; other buried valleys trend southward into the Kansas River Valley and northward into Nebraska or eastward into Missouri.

The bedrock valleys generally are filled with clayey glacial deposits, but most contain some sand and gravel capable of yielding adequate water supplies for domestic or stock uses, or small industries or towns. Wells completed in the coarsest sand and gravel may yield as much as $900 \mathrm{gal} / \mathrm{min}$, but less than $500 \mathrm{gal} / \mathrm{min}$ is more common (J.E. Denne and others, Kansas Geological Survey, written commun., 1991). Aquifer-test results for wells completed in the major buried valley extending from Nemaha County to Atchison County, Kansas, indicate tranmissivities of 335 to $3,430 \mathrm{ft}^{2} / \mathrm{d}$ and storage coefficients of 0.00002 to 0.002 (J.E. Denne and others, Kansas Geological Survey, written commun., 1991).

A hydrograph (fig. 23) of water levels for a 284 -ftdeep well completed in glacial deposits in a buried bedrock-valley aquifer in Nemaha County, Kansas, considered representative of such aquifers in the area, shows an overall range of about $17 \mathrm{ft}$ for the 36 periodic measurements made from 1984-94. The periodic or seasonal fluctuations shown may be from the effects of pumpage from the aquifer, but there is no general decline in water levels, which would indicate that such pumpage is not exceeding recharge to the aquifer.

\section{Bedrock Aquifers}

Because only the uppermost part of the Precambrian crystalline basement rocks commonly are 


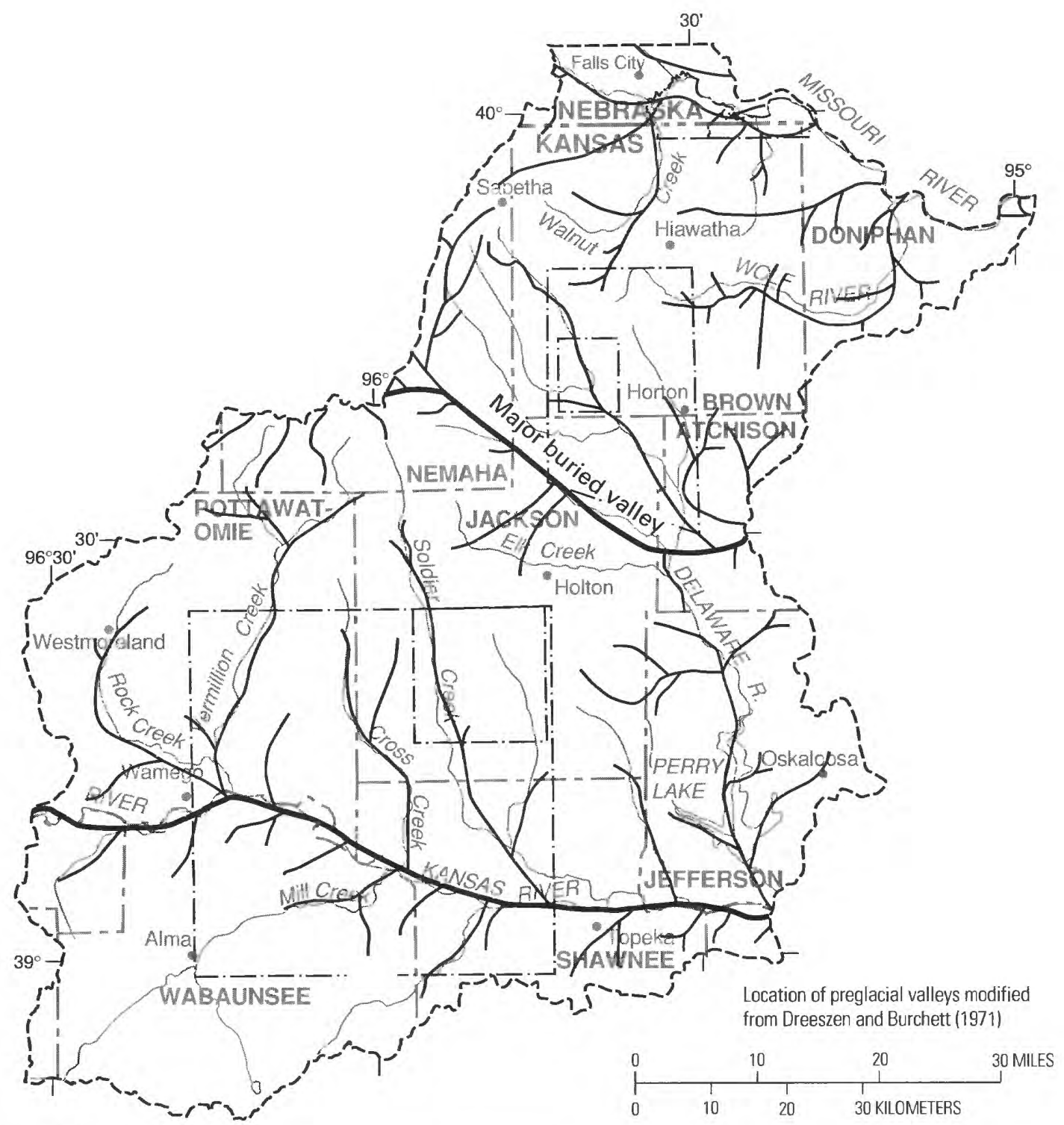

Base from U.S. Geological Survey digital data, 1:100,000, 1972

Lambert Conformal Conic projection Standard parallels $33^{\circ}$ and $45^{\circ}$

\section{EXPLANATION}

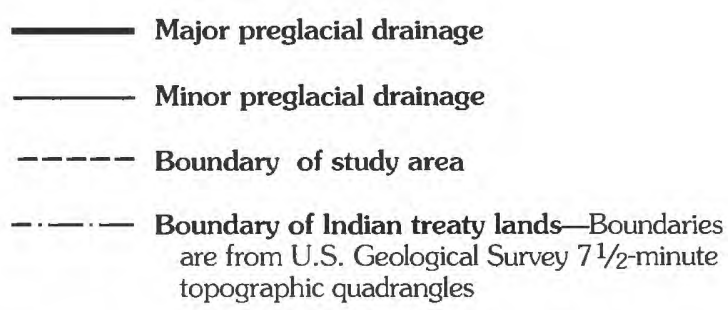

Figure 22. Location of preglacial valleys in study area.

fractured and covered by residual material, very small amounts of water may occur only in this upper part. Therefore, the basement rocks are not considered to be a usable source of water, and the Precambrian rock surface essentially represents the base of all water- bearing rocks in the area. Above this surface, the deep saline water-bearing bedrock aquifers are used for disposal of oilfield brines or are unused, and the shallow freshwater-bearing bedrock aquifers are used for minor water supplies. 


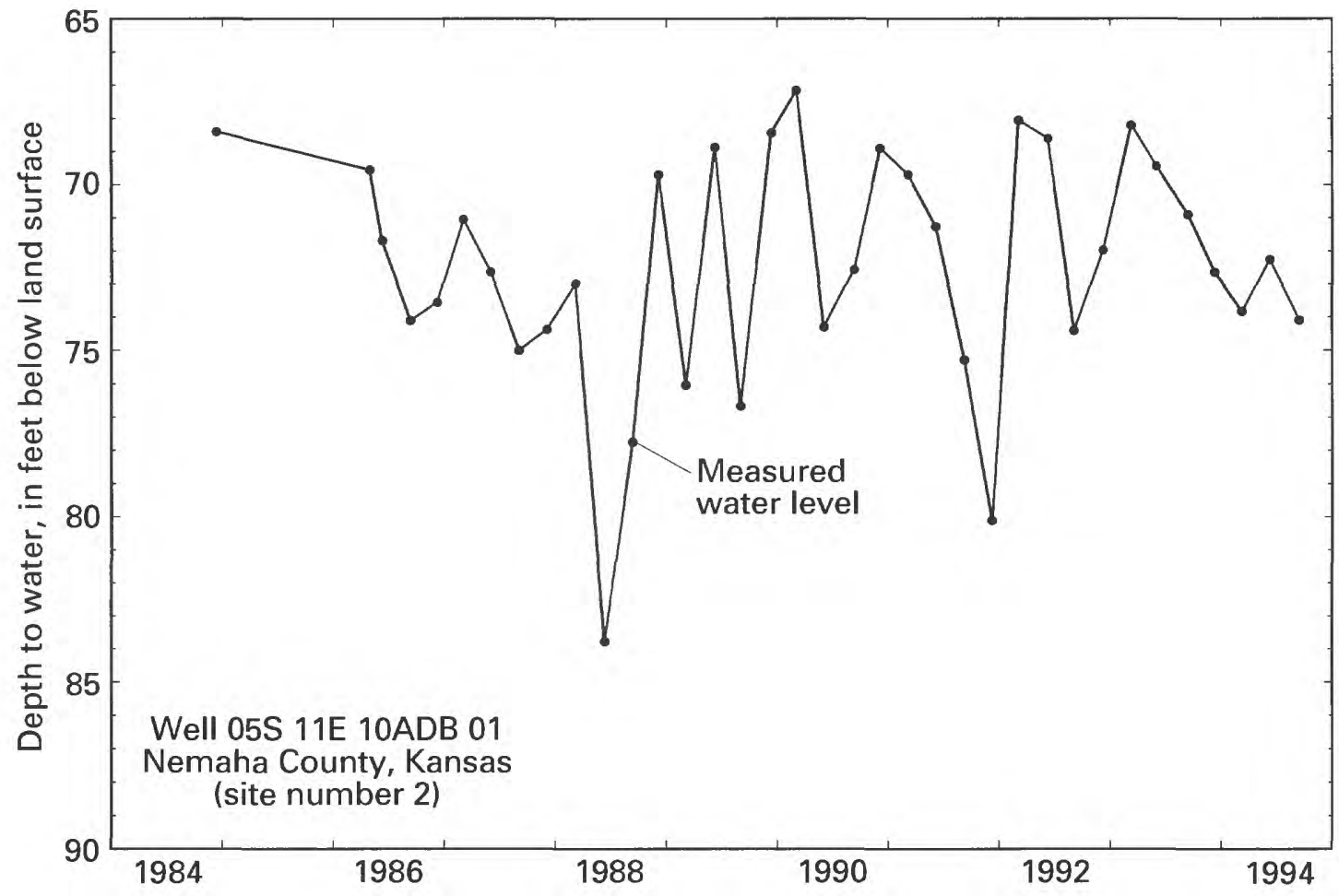

Figure 23. Water levels in well completed in a buried bedrock-valley aquifer in Nemaha County, Kansas, 1984-94. Well location shown in figure 17.

Deeply buried rocks of Late Cambrian through Late Mississippian age in Kansas have been defined by Jorgensen and others (1993) as the Western Interior Plains aquifer system and further divided into the lower aquifer units, confining unit, and an upper aquifer unit. Rocks of this aquifer system extend throughout the study area immediately above the crystalline basement rocks, except over part of the Nemaha Uplift where they are absent (figs. 4 and 5).

The lower aquifer units of the Western Interior Plains aquifer system consist of a thick series of mostly carbonate rocks of Late Cambrian through Early Devonian age comprised of limestone, dolostone, sandstone, and shale. Thicknesses of the lower units range from zero over the Nemaha Uplift to about $1,200 \mathrm{ft}$ in the Forest City Basin area. Just above the basement confining unit, rocks of Late Cambrian through Early Ordovician age are mostly dolomite with minor sandstone and chert. Most of the permeability attributed to these rocks is related to the unconformable surfaces where erosion and dissolution took place and water now moves through sinks and caverns in the karst-like zones beneath the buried surfaces. The water is too mineralized for most uses in the study area. However, these rocks are used extensively throughout Kansas, including the study area, to dispose of large quantities of oilfield brines by injection. Rocks of Middle Ordovician through Early Devonian age are comprised of dense limestone and dolostone alternating with thick beds of shale. Although some water may occur in fractures or solution channels, the rocks are not commonly used as a source of water because they are deeply buried and the water too mineralized.

The water in the lower aquifer units of the Western Interior Plains aquifer system is confined above by a non-water-yielding sequence of fine-grained, mostly clayey to silty shale deposits of Late Devonian to Early Mississippian age reaching as much as $300 \mathrm{ft}$ thick in the Forest City Basin part of the study area. The upper aquifer unit of the aquifer system consists of all the carbonate rocks of Mississippian age. Permeable zones in these rocks were formed by fracturing and dissolution of the dense limestones and dolostones, especially associated with erosional surfaces beneath unconformities. The top of this upper aquifer unit lies from about 300 to more than $1,000 \mathrm{ft}$ below sea level in the Forest City Basin of the study area, and the water is too mineralized for most uses. 
Above the deeply buried Western Interior Plains aquifer system and extending locally to the land surface, rocks of Late Mississippian through Permian age in the study area have been designated as the Western Interior Plains confining system (Jorgensen and others, 1993). These rocks mostly consist of non-water-yielding shale and evaporite deposits, with minor aquifers of limestone, sandstone, and coal, and range from several hundred feet thick over the Nemaha Uplift to about 2,000 ft thick in the deeper part of the Forest City Basin.

Most wells in the study area derive their water from relatively permeable unconsolidated deposits, but where unconsolidated deposits are thin, absent, or too fine grained, wells may be completed in bedrock aquifers. Most bedrock wells in the study area are finished in limestone, but occasionally they are finished in sandstone, coal, or fractured shale beds in Pennsylvanian- and Permian-age rocks. Generally, these wells yield small quantities of water (less than 1 to $10 \mathrm{gal} / \mathrm{min}$ ) to wells and are capable of supplying water only for domestic, farm, or stock uses. A hydrograph (fig. 24) of water levels in a 75-ft-deep small-town supply well in Brown County, Kansas, completed in Pennsylvanian-age limestone shows an overall water-level fluctuation of about $10 \mathrm{ft}$ for the 19 periodic measurements made from 1960-68 and is considered representative of bedrock-aquifer wells.

\section{WATER QUALITY}

Principal factors affecting the water quality in the study area include geology, agricultural practices, and oil and gas activities. Dissolution of carbonate rocks and sediments in northeastern Kansas and southeastern Nebraska, which consist primarily of limestone and dolomite, cause calcium, magnesium, and bicarbonate to be the dominant dissolved constituents in water. Exposure of water to evaporite deposits can increase the concentrations of sodium and chloride. In addition, sulfate concentrations in water may be high near dolomite or coal deposits. Glacial silt and clay deposits coupled with agricultural practices may cause increased suspended-sediment concentrations. Other agricultural practices may result in elevated pesticide and fecal bacteria concentrations in surface runoff.

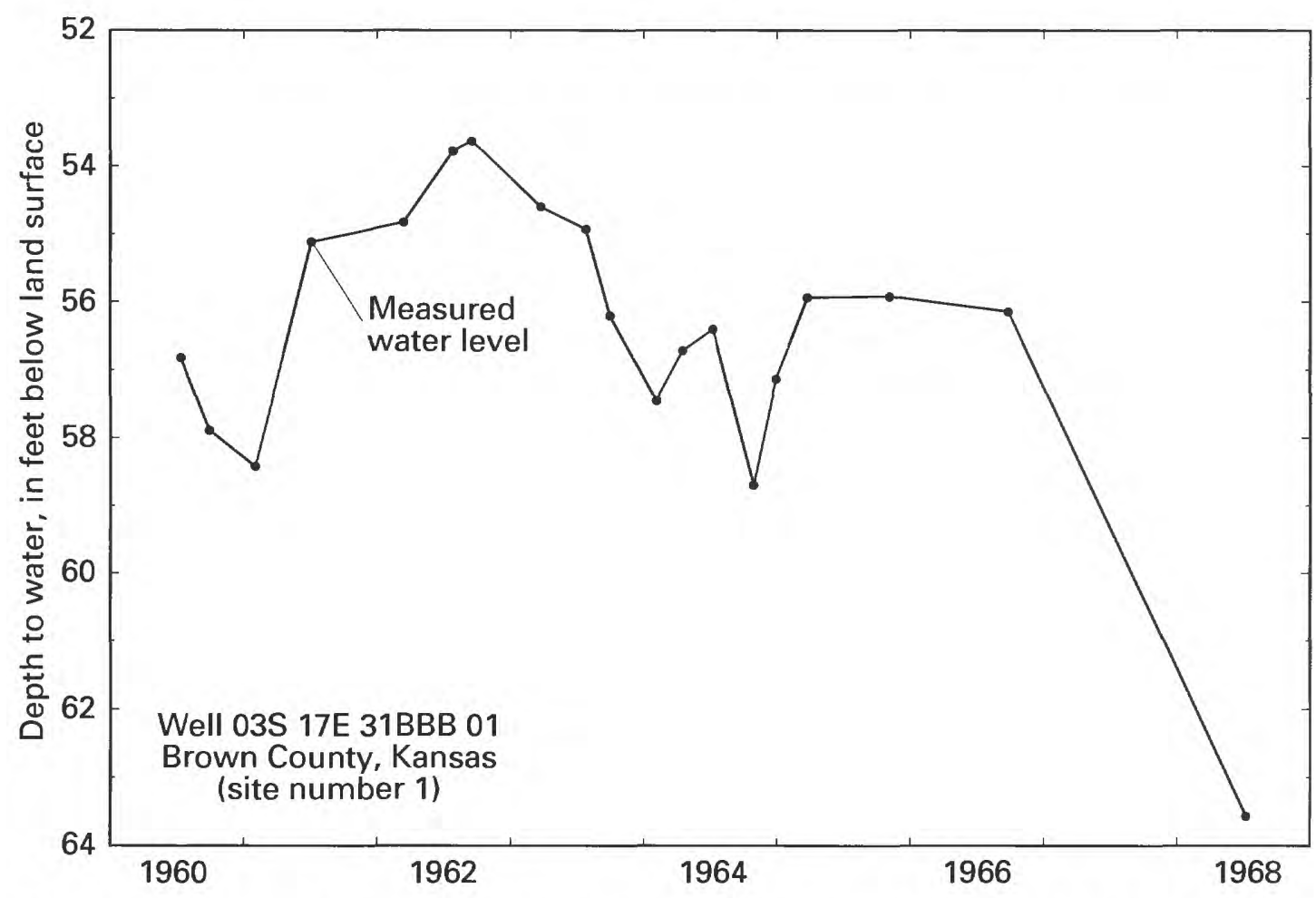

Figure 24. Water levels in well completed in an unconfined aquifer of Pennsylvanian-age limestone in Brown County, Kansas, 1960-68. Well location shown in figure 17. 
Hydrogen activity of water is measured by the $\mathrm{pH}$. According to $\mathrm{Hem}(1985$, p. 64), the $\mathrm{pH}$ of river water in areas not affected by pollution generally ranges from 6.5 to 8.5 standard units. Where photosynthesis by aquatic organisms takes up carbon dioxide during daylight and releases carbon dioxide at night, $\mathrm{pH}$ fluctuations may occur, and the maximum $\mathrm{pH}$ value may reach as high as 9.0. In contrast, other factors such as oxidation of dissolved ferrous iron, lower the $\mathrm{pH}$. The USEPA (U.S. Environmental Protection Agency, 1986) recommends a $\mathrm{pH}$ range of 6.5 to 8.5 (limits of SMCL) for drinking-water supplies because, within that range, the $\mathrm{pH}$ can be adjusted easily by treatment processes.

On the basis of available water-quality analyses, values of $\mathrm{pH}$ in surface water in the study area (fig. 25A) typically are between about 7.5 and 8.4 standard units. Surface water in the Wolf River Basin has relatively high values of $\mathrm{pH}$ from about 8.0 to 8.4 standard units. Surface water $\mathrm{pH}$ in the Big Nemaha, middle Kansas, and Delaware River Basins shares common values from about 7.5 to 8.0 standard units. In ground water (data from all aquifers combined), $\mathrm{pH}$ (fig. 25B) generally is lower because bicarbonate concentration in the water is the determining factor rather than photosynthesis. The $\mathrm{pH}$ of ground water is nearly identical in all four basins, with values typically from 7.1 to 7.5 standard units.

\section{Major lons}

Calcium is a major constituent of carbonate rocks (Hem, 1985, p. 85), such as limestone and dolomite, and it dissolves readily in water; therefore, the calcium concentration in water from areas with carbonate rocks and sediments tends to be higher than in other areas. Calcium concentrations in surface water of the study area result primarily from the dissolution of carbonate rocks and typically are between about 50 and $120 \mathrm{mg} / \mathrm{L}$ (fig. 26A). Calcium concentrations in ground water (fig. 26B) are similar to those in surface water; however, there are several extreme concentrations, as high as $600 \mathrm{mg} / \mathrm{L}$.

Magnesium is a common alkaline-earth metal and is essential in plant and animal nutrition (Hem, 1985, p. 96-97). The principal sources for magnesium in the study area are carbonate rocks such as dolomite and limestone. Magnesium concentrations in surface water of the study area typically are between about 10 and $30 \mathrm{mg} / \mathrm{L}$ (fig. $27 \mathrm{~A}$ ), or from 20 to 30 percent of the calcium concentration. This is consistent with the dissolution of carbonate rocks. There is nothing in figures $26 A$ and $27 A$ to suggest any major differences between calcium and magnesium concentrations in any of the four major drainage basins within the study area. As with calcium, magnesium concentrations in ground water (fig. $27 \mathrm{~B}$ ) are similar to those in surface water. Concentrations in ground water typically are a little higher, from about 10 to $40 \mathrm{mg} / \mathrm{L}$, with several extreme concentrations as high as $180 \mathrm{mg} / \mathrm{L}$.

Sodium is the most abundant member of the alkali-metal group of elements, and when dissolved, it tends to remain in solution (Hem, 1985, p. 100). Natural sources include the weathering of plagioclase feldspar and the dissolution of sodium salts from sedimentary rocks. Human-related sources include septic systems and as a byproduct of water treatment (it is discharged by water softeners and reverse-osmosis units). The USEPA (U.S. Environmental Protection Agency, 1986) established an HAL of $20 \mathrm{mg} / \mathrm{L}$ for people who are on very restricted sodium diets.

Sodium concentrations in surface water of the study area typically range from about 12 to $50 \mathrm{mg} / \mathrm{L}$ (fig. 28A). The median concentrations in surface water from all four major drainage basins are either at or greater than the $20-\mathrm{mg} / \mathrm{L}$ HAL. The probable cause is primarily the dissolution of sodium salts from sedimentary rocks. Sodium concentrations in ground water (fig. $28 B$ ) typically range from about 10 to $60 \mathrm{mg} / \mathrm{L}$. The median value for ground water from the Wolf River Basin is about $11 \mathrm{mg} / \mathrm{L}$, which is less than the $20-\mathrm{mg} / \mathrm{L}$ HAL. Median concentrations in ground water from the Big Nemaha, middle Kansas, and Delaware River Basins equal or exceed the 20-mg/L HAL. Extreme concentrations range to as much as $3,000 \mathrm{mg} / \mathrm{L}$ and probably result from the dissolution of sodium salts in the rock formations.

Potassium concentrations generally are much lower than sodium concentrations in most natural water (Hem, 1985, p. 105). Where the sodium concentration substantially exceeds $10 \mathrm{mg} / \mathrm{L}$, the potassium concentration commonly is one-half to a one-tenth that of sodium. Potassium concentrations in surface water in the study area typically are from about 3 to $8 \mathrm{mg} / \mathrm{L}$ (fig. 29A). Median concentrations in all four major drainage basins typically are between 4 and $5 \mathrm{mg} / \mathrm{L}$, which is approximately 20 percent of the median concentrations for sodium. With the exception of the 


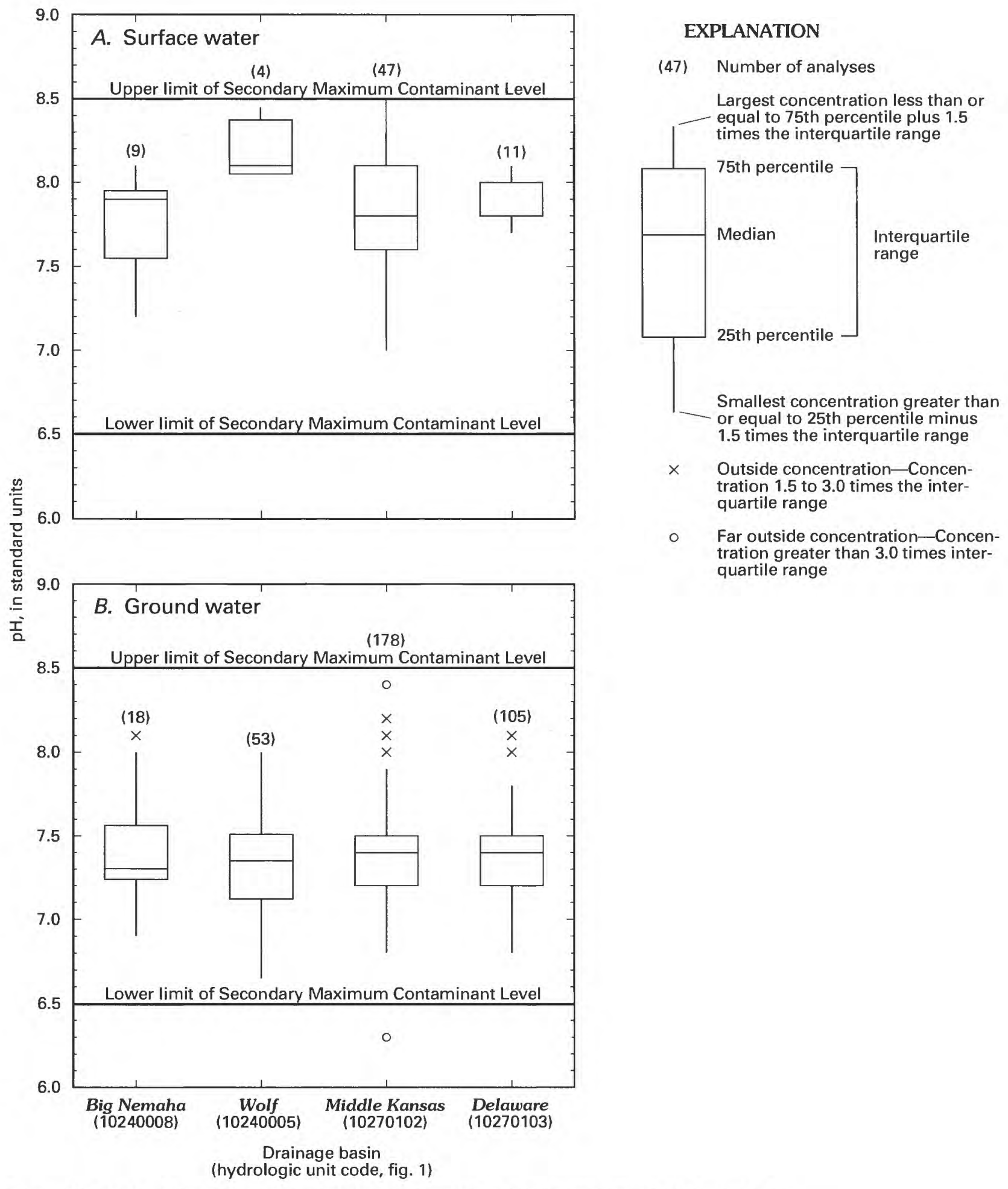

Figure 25. Distribution of $\mathrm{pH}$ values in $(A)$ surface water and $(B)$ ground water of study area. 


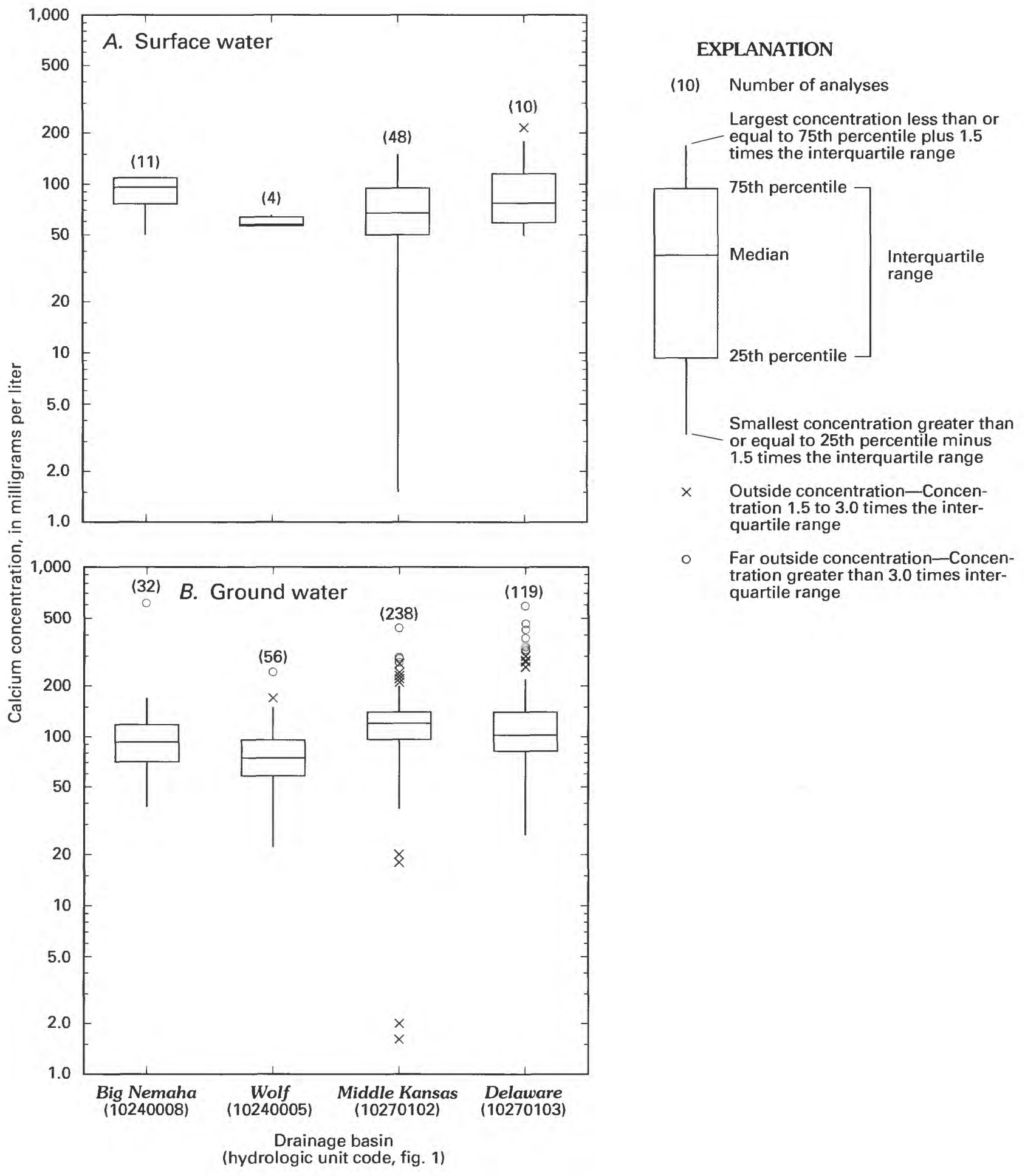

Figure 26. Distribution of calcium concentrations in $(A)$ surface water and $(B)$ ground water of study area. 


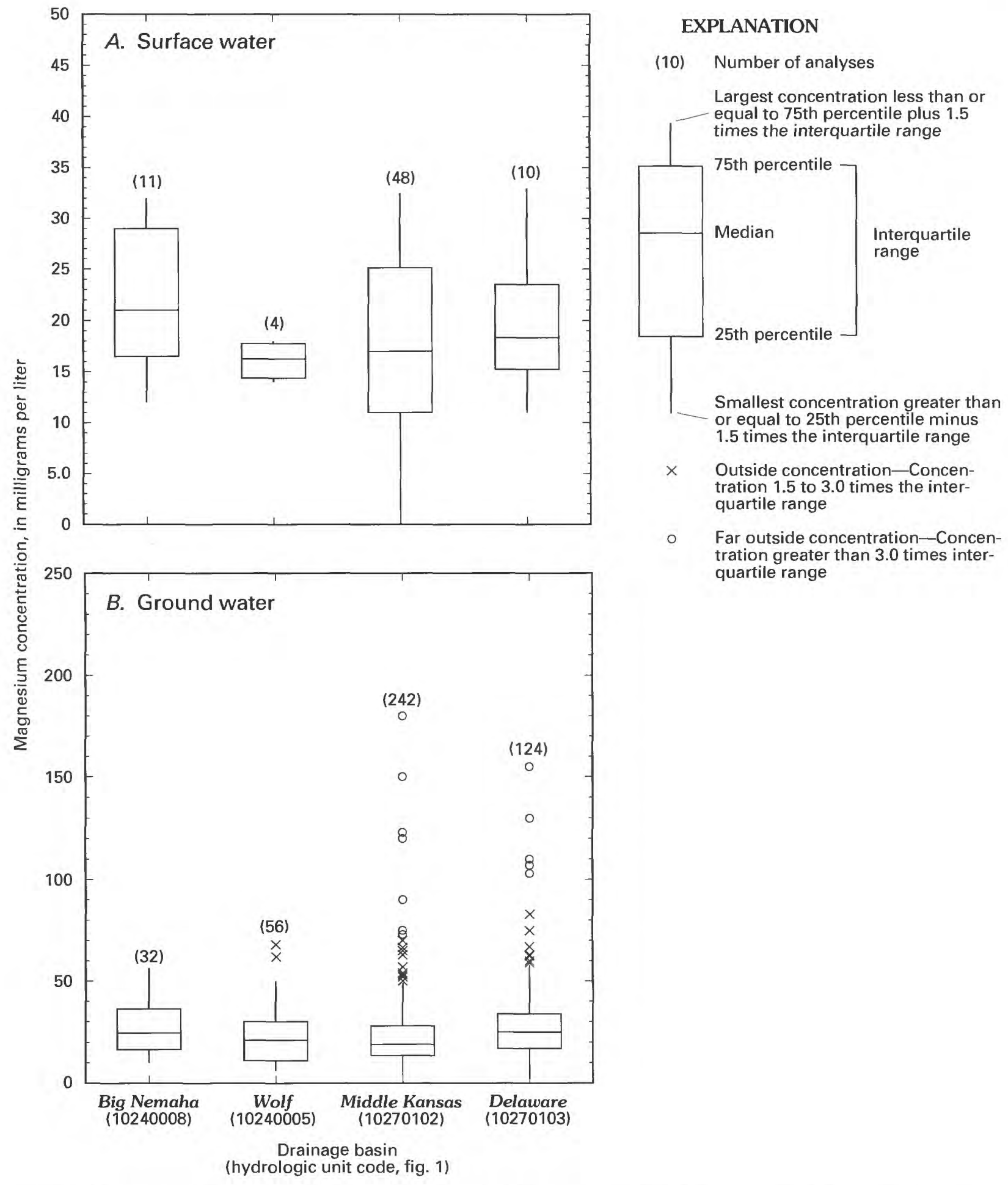

Figure 27. Distribution of magnesium concentrations in $(A)$ surface water and $(B)$ ground water of study area. 


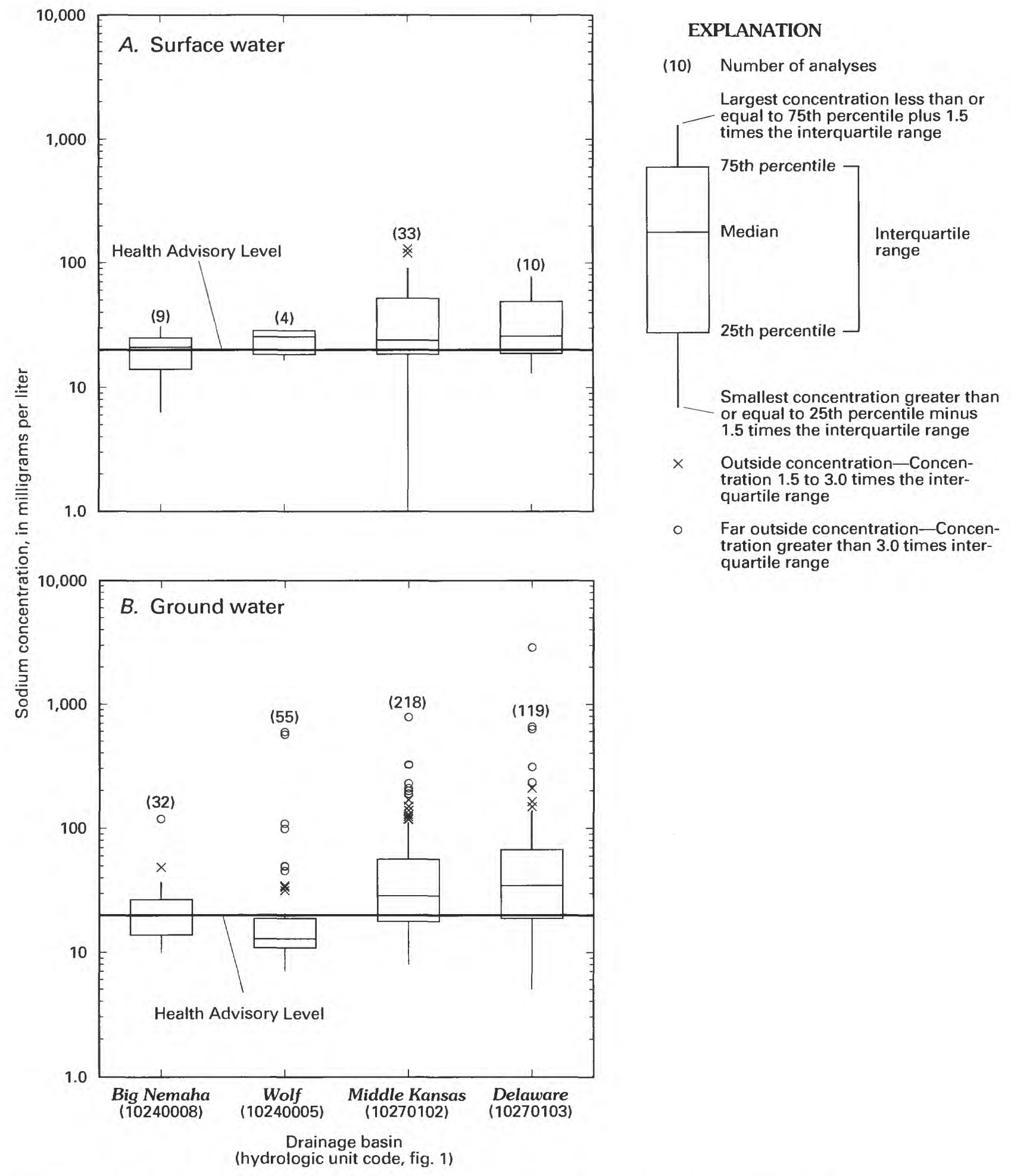

Figure 28. Distribution of sodium concentrations in $(A)$ surface water and $(B)$ ground water of study area. 


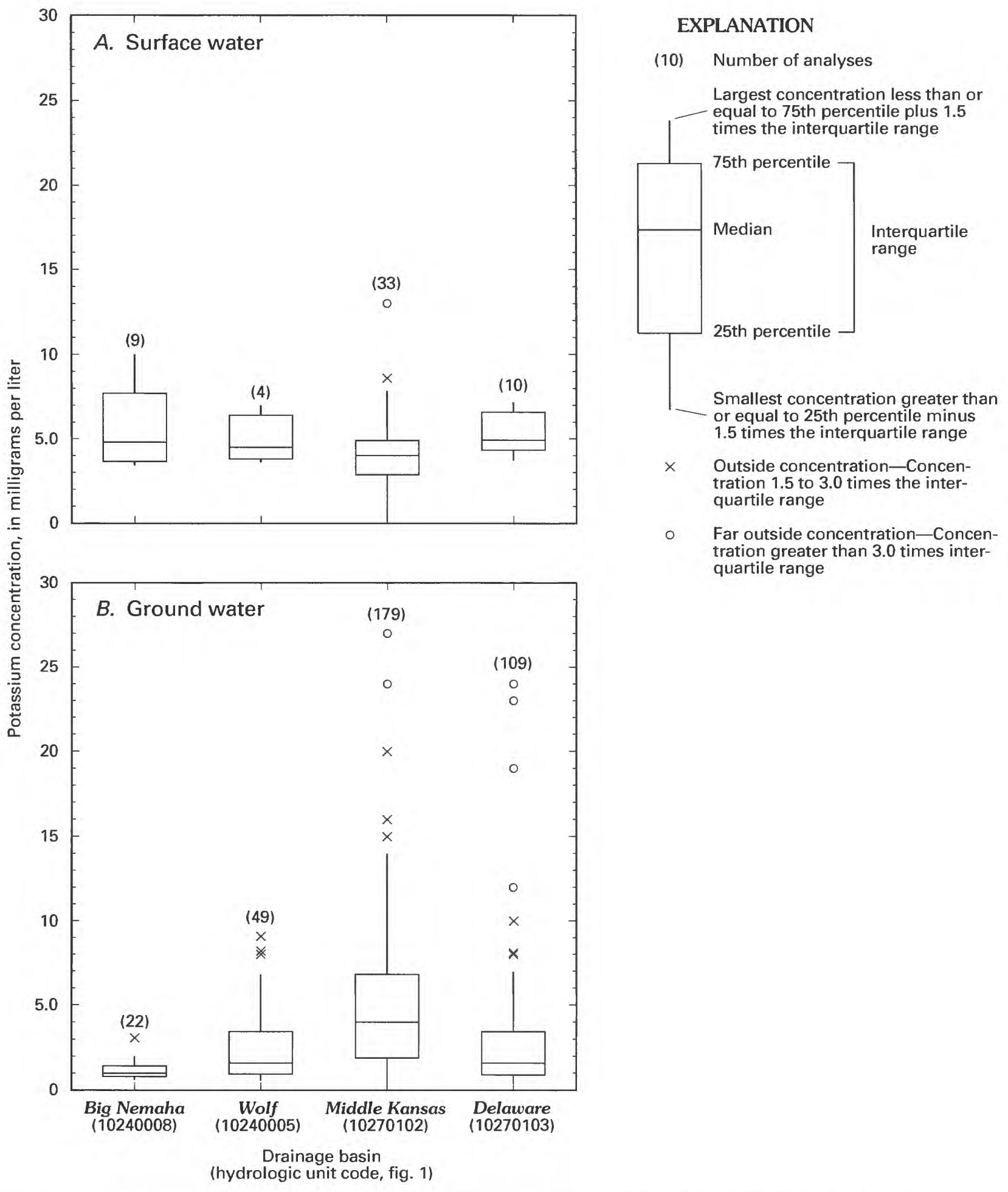

Figure 29. Distribution of potassium concentrations in $(A)$ surface water and $(B)$ ground water of study area. 
middle Kansas River Basin, potassium concentrations in ground water (fig. 29B) tend to be lower than in surface water. Concentrations in ground water from the Big Nemaha, Wolf, and Delaware Basins typically are from about $1 \mathrm{mg} / \mathrm{L}$ to a little more than $3 \mathrm{mg} / \mathrm{L}$. Potassium concentrations in ground water typically are from 2 to about $7 \mathrm{mg} / \mathrm{L}$ in the middle Kansas Basin. Some ground water in the middle Kansas and Delaware Basins contains extreme concentrations to about $27 \mathrm{mg} / \mathrm{L}$.

Bicarbonate concentrations in water are calculated by dividing alkalinity by 0.8202 (Hem, 1985, p. 55 , 57). Alkalinity is defined as the capacity of a solute to neutralize acid (Hem, 1985, p. 106-109) and is expressed as milligrams per liter of calcium carbonate $\left(\mathrm{CaCO}_{3}\right)$. The primary source for bicarbonate in the study area is the dissolution of carbonate rocks and sediments. Bicarbonate concentrations in surface water (fig. 30A) in the study area typically are from about 160 to $340 \mathrm{mg} / \mathrm{L}$, generally proportional to the concentrations of calcium and magnesium in surface water. Bicarbonate concentrations in ground water (fig. $30 \mathrm{~B}$ ) generally are higher than in surface water because ground water in contact with carbonate rocks and sediments is less likely to be diluted by water from other sources. Bicarbonate concentrations in ground water of the study area typically are from about 200 to about $440 \mathrm{mg} / \mathrm{L}$, with extreme concentrations to about $900 \mathrm{mg} / \mathrm{L}$.

Chloride is present in all natural water, but the concentrations generally are low (Hem, 1985, p. 118-119). The most important natural source in the study area is dissolution of halite from sedimentary rocks. On the basis of taste, an SMCL of $250 \mathrm{mg} / \mathrm{L}$ in drinking-water supplies was established for chloride by the USEPA (U.S. Environmental Protection Agency, 1986, 1994). Chloride concentrations in surface water (fig. 31A) in the study area typically are from about 9 to $60 \mathrm{mg} / \mathrm{L}$. Median chloride concentrations in ground water (fig. $31 \mathrm{~B}$ ) are approximately the same as in surface water, typically from about 6 to $60 \mathrm{mg} / \mathrm{L}$. About 3 percent of the analyses (12) equal or exceed the 250-mg/L SMCL.

Natural sources of sulfate (Hem, 1985, p. 112-117) in water include the weathering of sulfurbearing minerals, such as pyrite and gypsum, volcanic discharges to the atmosphere, and biologic and biochemical processes. Human-related sources include industrial discharges to both streams and the atmosphere and the combustion of fossil fuels, such as coal and gasoline. The USEPA (U.S. Environmental Protection Agency, 1986, 1994) established an SMCL of $250 \mathrm{mg} / \mathrm{L}$ in drinking water to prevent laxative effects. Sulfate concentrations in surface water of the study area (fig. 32A) typically are from about 30 to 170 $\mathrm{mg} / \mathrm{L}$. Three analyses, one in the middle Kansas River Basin and two in the Delaware River Basin, have concentrations that exceed the $250-\mathrm{mg} / \mathrm{L}$ SMCL. Sulfate concentrations in ground water (fig. $32 \mathrm{~B}$ ) generally are less than in surface water, typically from about 15 to $140 \mathrm{mg} / \mathrm{L}$. Extreme concentrations in the Big Nemaha, middle Kansas, and Delaware River Basins were as large as $1,700 \mathrm{mg} / \mathrm{L}$.

\section{Dissolved Solids}

Dissolved solids in natural water consist primarily of the cations calcium, magnesium, sodium, and potassium and the anions bicarbonate, chloride, and sulfate. According to the USEPA (U.S. Environmental Protection Agency, 1986), excess dissolved solids are objectionable in drinking water because of possible physiological effects, unpalatable mineral tastes, and higher costs because of corrosion or the necessity for additional treatment. The SMCL for dissolved solids is $500 \mathrm{mg} / \mathrm{L}$.

The typical range for dissolved solids in surface water (fig. 33A) in the study area is from about 270 to $550 \mathrm{mg} / \mathrm{L}$. Several samples have concentrations exceeding the 500-mg/L SMCL. Concentrations of dissolved solids in ground water of the study area (fig. $33 B$ ) generally are greater than in surface water, typically from about 270 to $700 \mathrm{mg} / \mathrm{L}$. High concentrations generally are less than $3,500 \mathrm{mg} / \mathrm{L}$. One ground-water sample has a dissolved-solids concentration of $9,000 \mathrm{mg} / \mathrm{L}$, which results from dissolution of sodium chloride from the surrounding rocks.

\section{Metals}

The USEPA (U.S. Environmental Protection Agency, 1986, 1994) has established a SMCL of $300 \mu \mathrm{g} / \mathrm{L}$ for iron. If iron is present in water in excessive amounts, it forms a red iron-oxide precipitate that stains laundry and plumbing fixtures and, therefore, is an objectionable constituent in domestic and industrial water supplies (Hem 1985, p. 77). Very few analyses are available for surface water. Total iron concentrations in surface water (fig. 34A) within the study area 


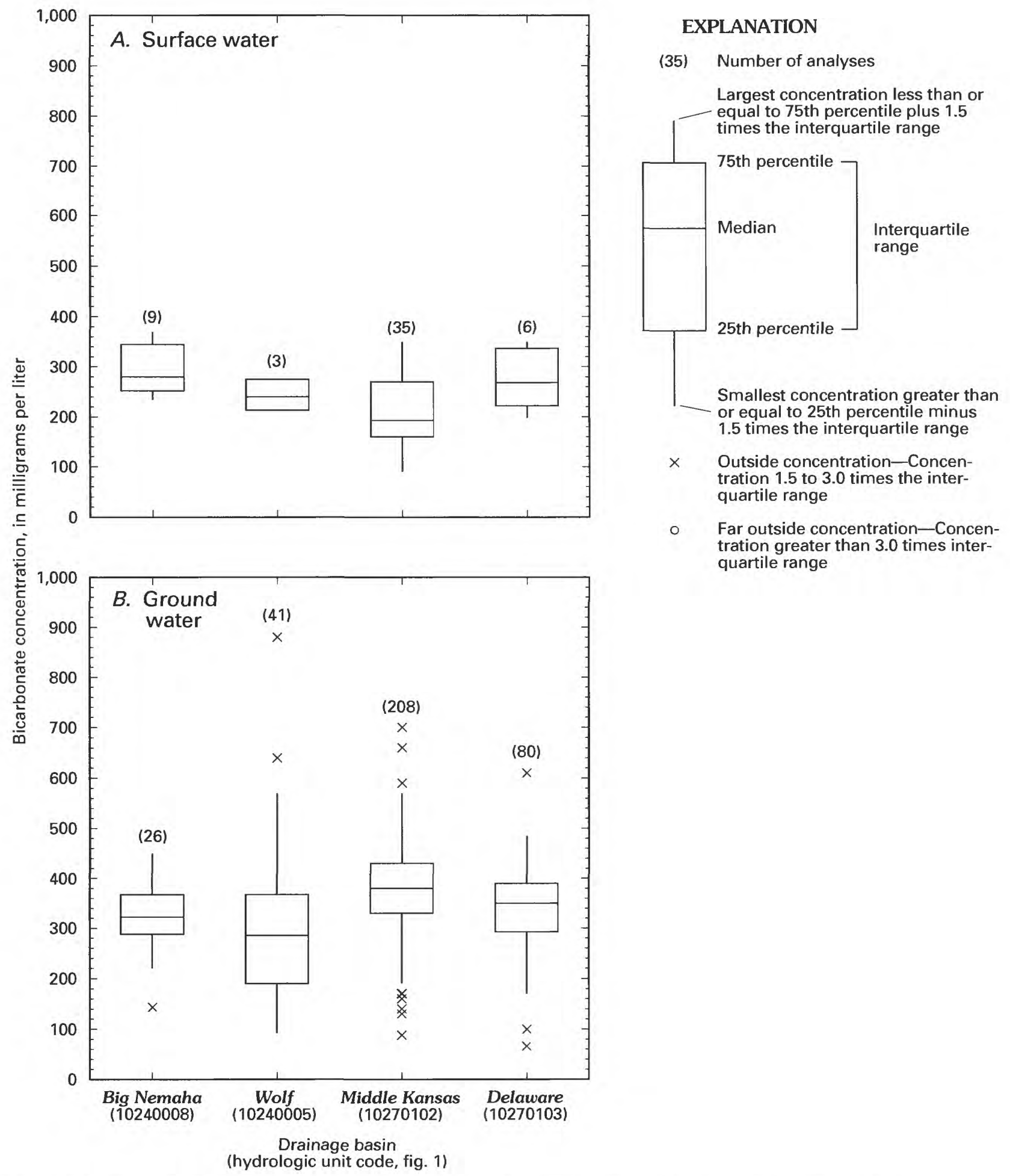

Figure 30. Distribution of bicarbonate concentrations in $(A)$ surface water and $(B)$ ground water of study area. 


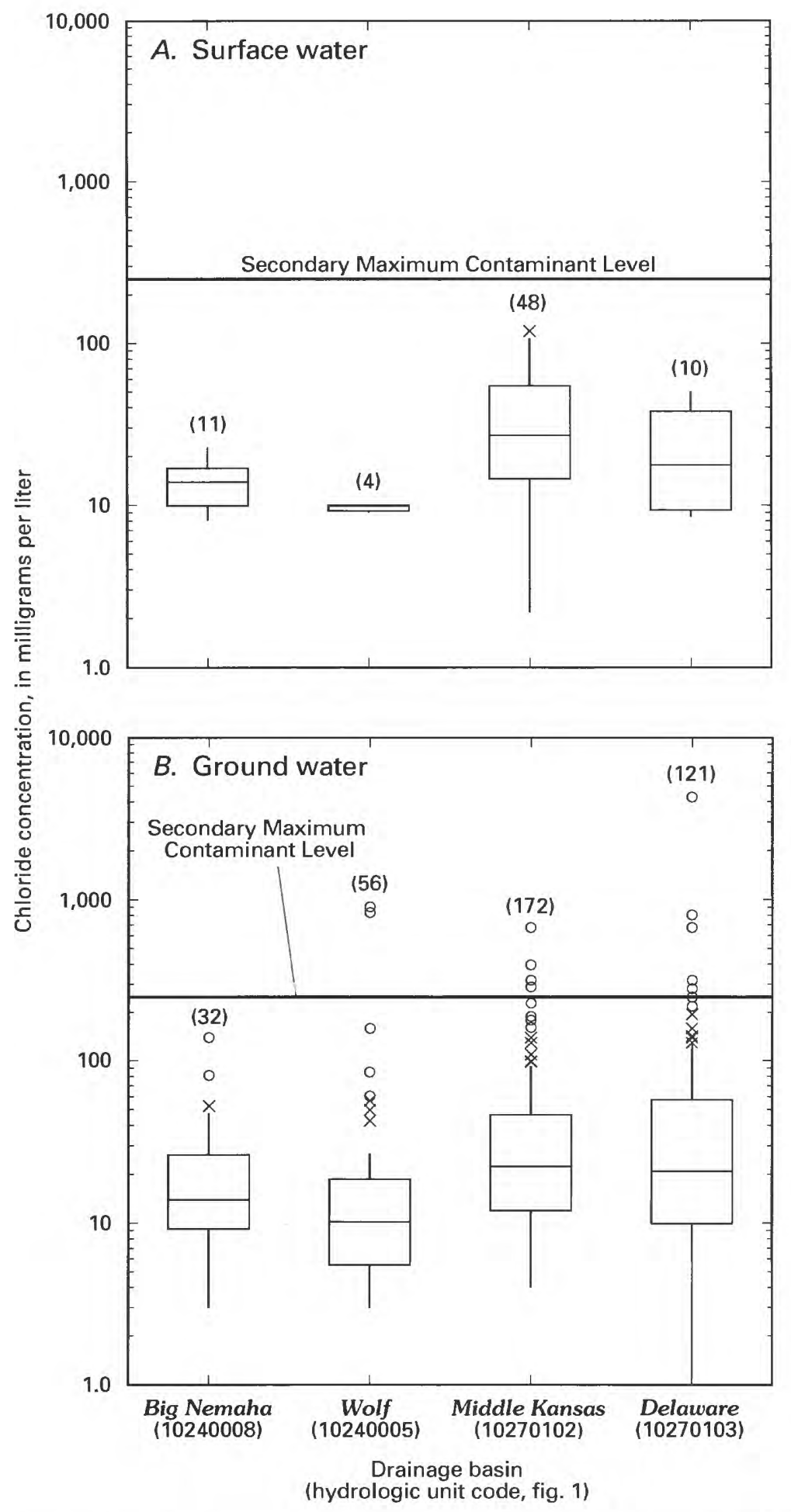

\section{EXPLANATION}

(10) Number of analyses

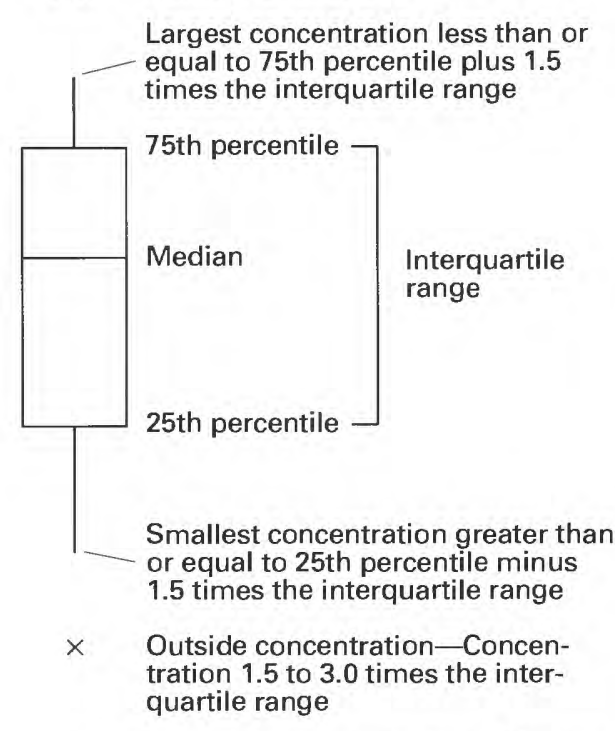

- Far outside concentration-Concentration greater than 3.0 times interquartile range

Figure 31. Distribution of chloride concentrations in $(A)$ surface and $(B)$ ground water of study area. 


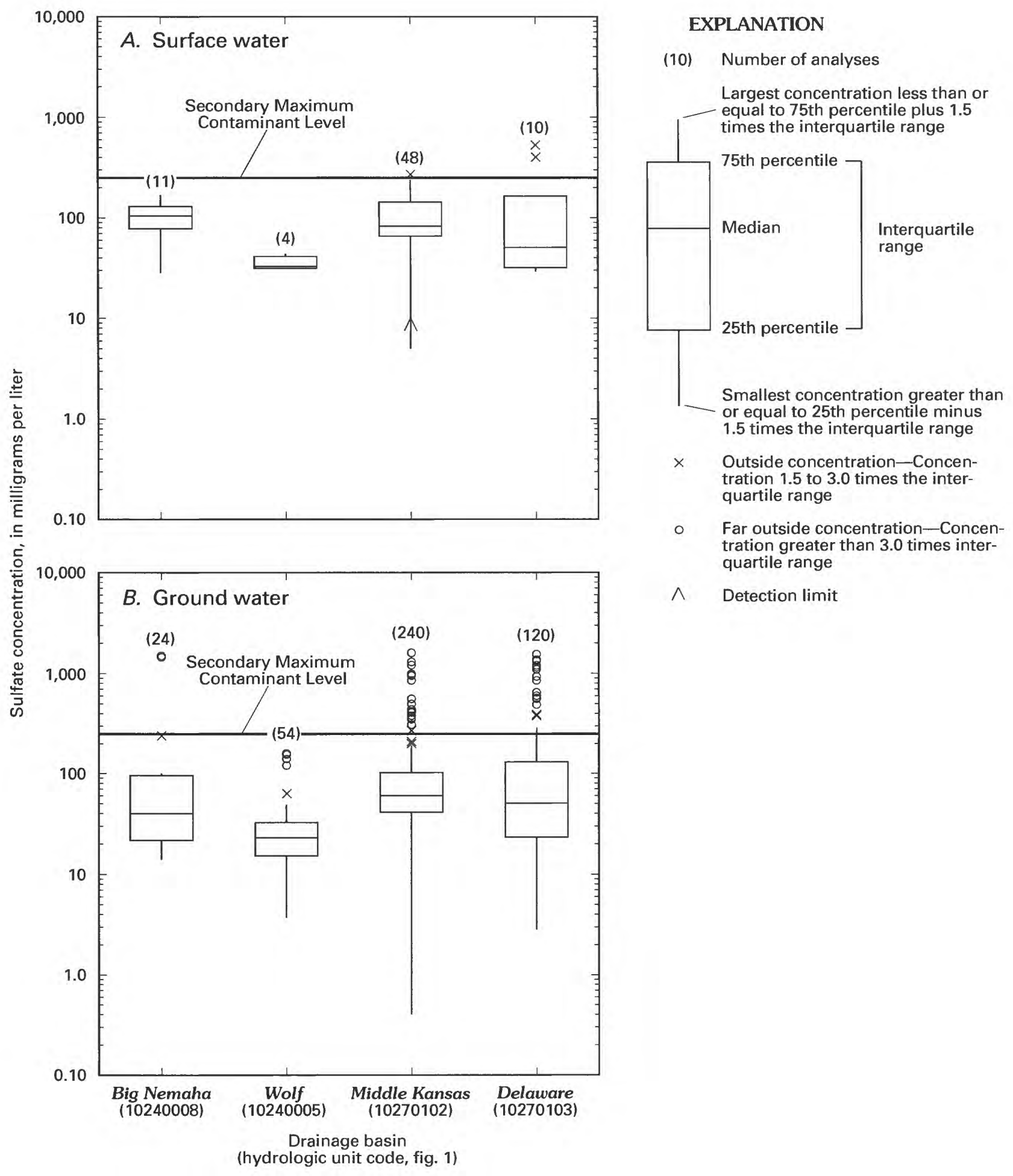

Figure 32. Distribution of sulfate concentrations in $(A)$ surface water and $(B)$ ground water of study area. 


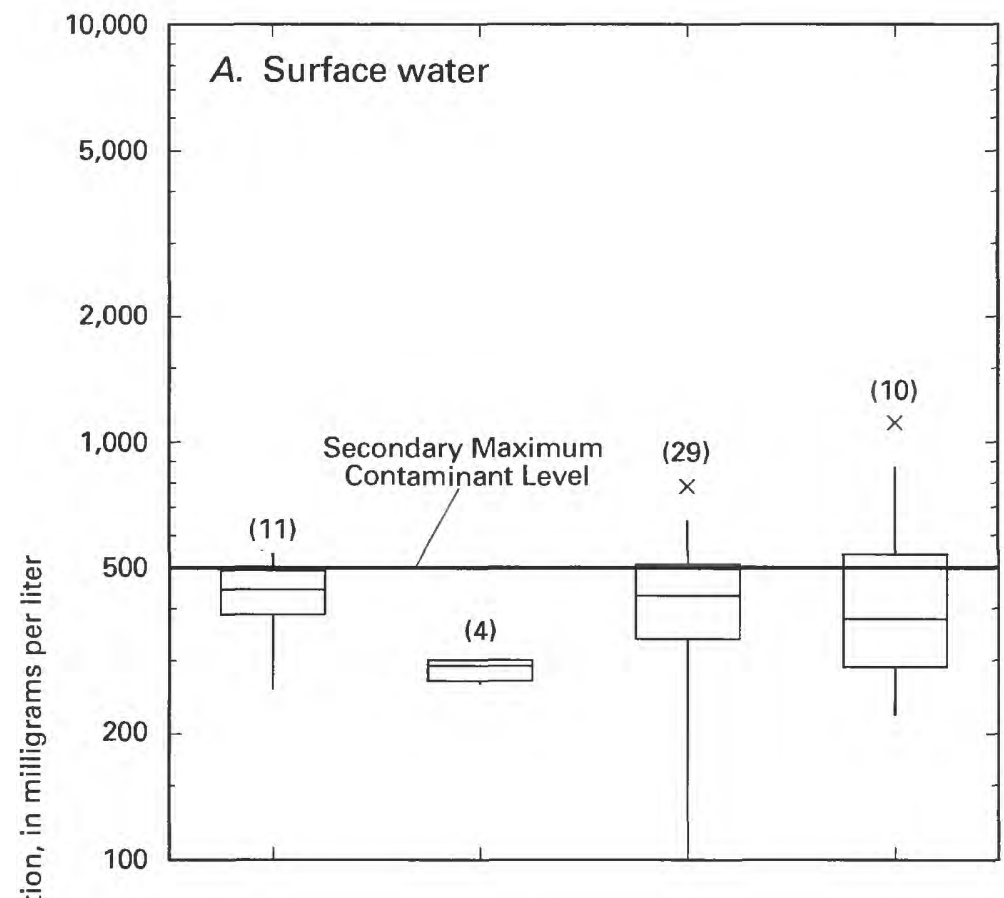

\section{EXPLANATION}

(10) Number of analyses

Largest concentration less than or

equal to 75 th percentile plus 1.5

times the interquartile range

10,000

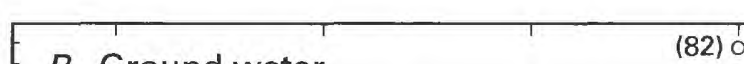

(82) 0

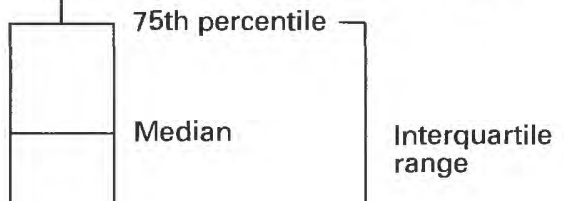

B. Ground water
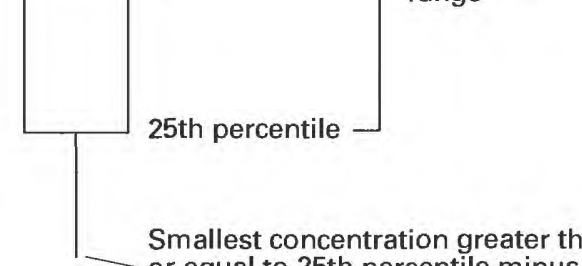

mallest concentration greater than or equal to 25 th percentile minus 1.5 times the interquartile range

$\times \quad$ Outside concentration-Concentration 1.5 to 3.0 times the interquartile range

- Far outside concentration-Concentration greater than 3.0 times interquartile range 


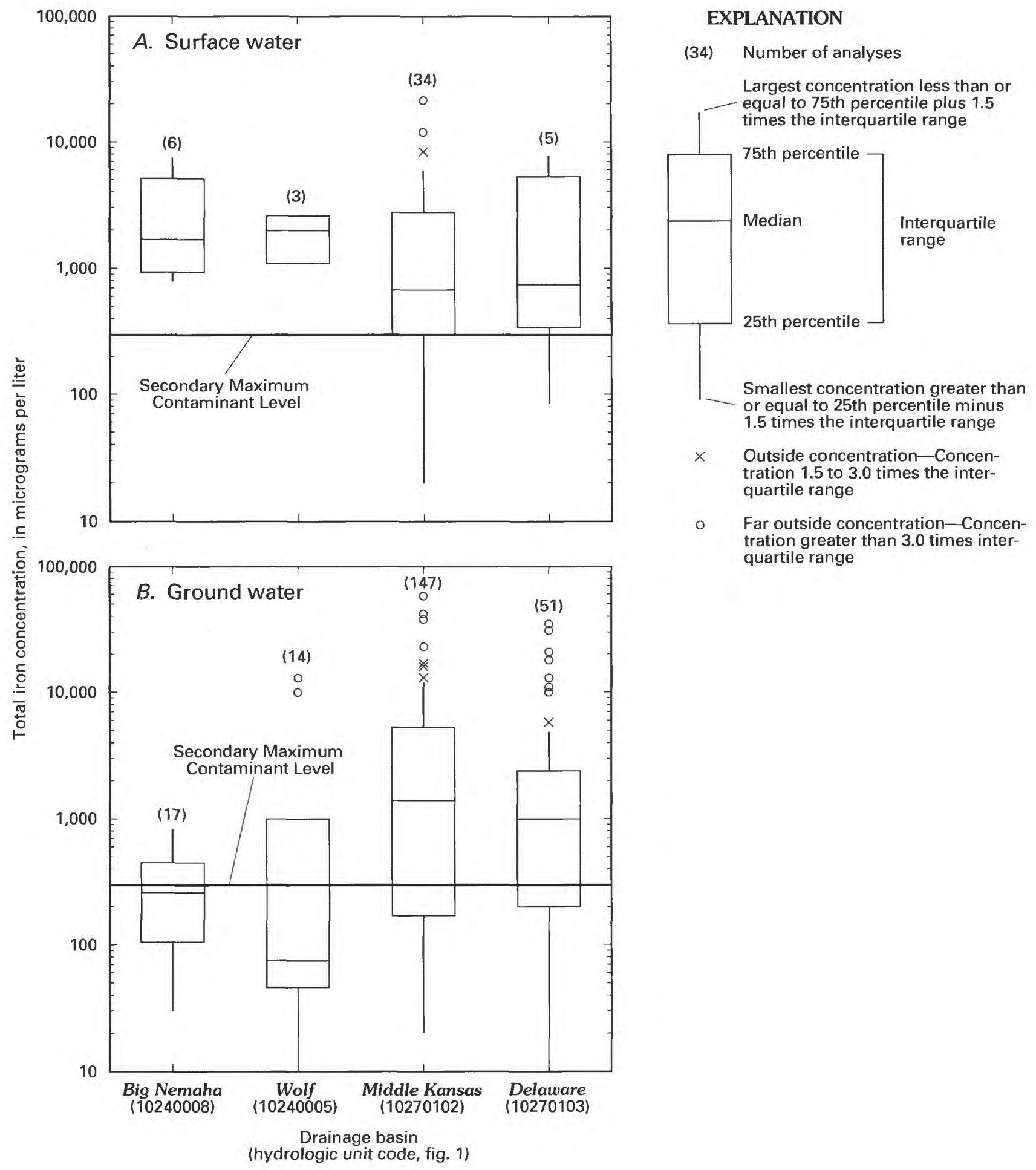

Figure 34. Distribution of total iron concentrations in $(A)$ surface water and $(B)$ ground water of study area. 
typically are from 300 to about $5,000 \mu \mathrm{g} / \mathrm{L}$, with one concentration from the middle Kansas River Basin exceeding $20,000 \mu \mathrm{g} / \mathrm{L}$. Surface water in all of the four major drainage basins, therefore generally exceeds the $300-\mu \mathrm{g} / \mathrm{L}$ SMCL. These limits are for drinking water that has been treated. If source water contains iron concentrations that are higher than $300 \mu \mathrm{g} / \mathrm{L}$, the iron generally will be removed during the treatment process. Total iron concentrations in ground water (fig. $34 B$ ) typically are from about 45 to $5,000 \mu \mathrm{g} / \mathrm{L}$, with some concentrations as high as about $60,000 \mu \mathrm{g} / \mathrm{L}$ in the middle Kansas River Basin. High concentrations of iron in ground water are generally caused by reducing conditions where there is little or no dissolved oxygen.

As with iron, manganese forms a staining precipitate (black). The SMCL for manganese is $50 \mu \mathrm{g} / \mathrm{L}$ (U.S. Environmental Protection Agency, 1986, 1994). Total manganese concentrations in surface water typically are between 70 and $400 \mu \mathrm{g} / \mathrm{L}$ in all four major drainage basins (fig. 35), exceeding the SMCL. Not enough data are available to evaluate manganese concentrations in ground water of the study area.

Lead is a minor constituent in water throughout the study area, with concentrations generally less than or near the detection limit of $10 \mu \mathrm{g} / \mathrm{L}$. The MCL for lead in treated water is $15 \mu \mathrm{g} / \mathrm{L}$ (U.S. Environmental Protection Agency, 1986, 1994). In a study of urban runoff in Topeka, Kansas, Pope and Bevans (1986) found total lead concentrations from less than the detection limit to $800 \mu \mathrm{g} / \mathrm{L}$. By correlating total lead concentration to streamflow, they determined that the largest concentrations occurred during storm streamflow from the more urban basins.

\section{Nutrients}

Nitrogen and phosphorus are essential nutrients for plant growth. Dense algal growths or blooms sometimes occur in lakes and streams that periodically receive increased concentrations of nitrogen or phosphorus. These growths cause problems with other aquatic life when the water body becomes overloaded with oxidizable debris resulting from sudden dieback of algae (Hem, 1985, p. 128).

Nitrate is formed by complete oxidation of ammonium ions by soil or water microorganisms, and nitrite is formed from the nitrate or ammonium ions by microorganisms found in soil, water, sewage, and the
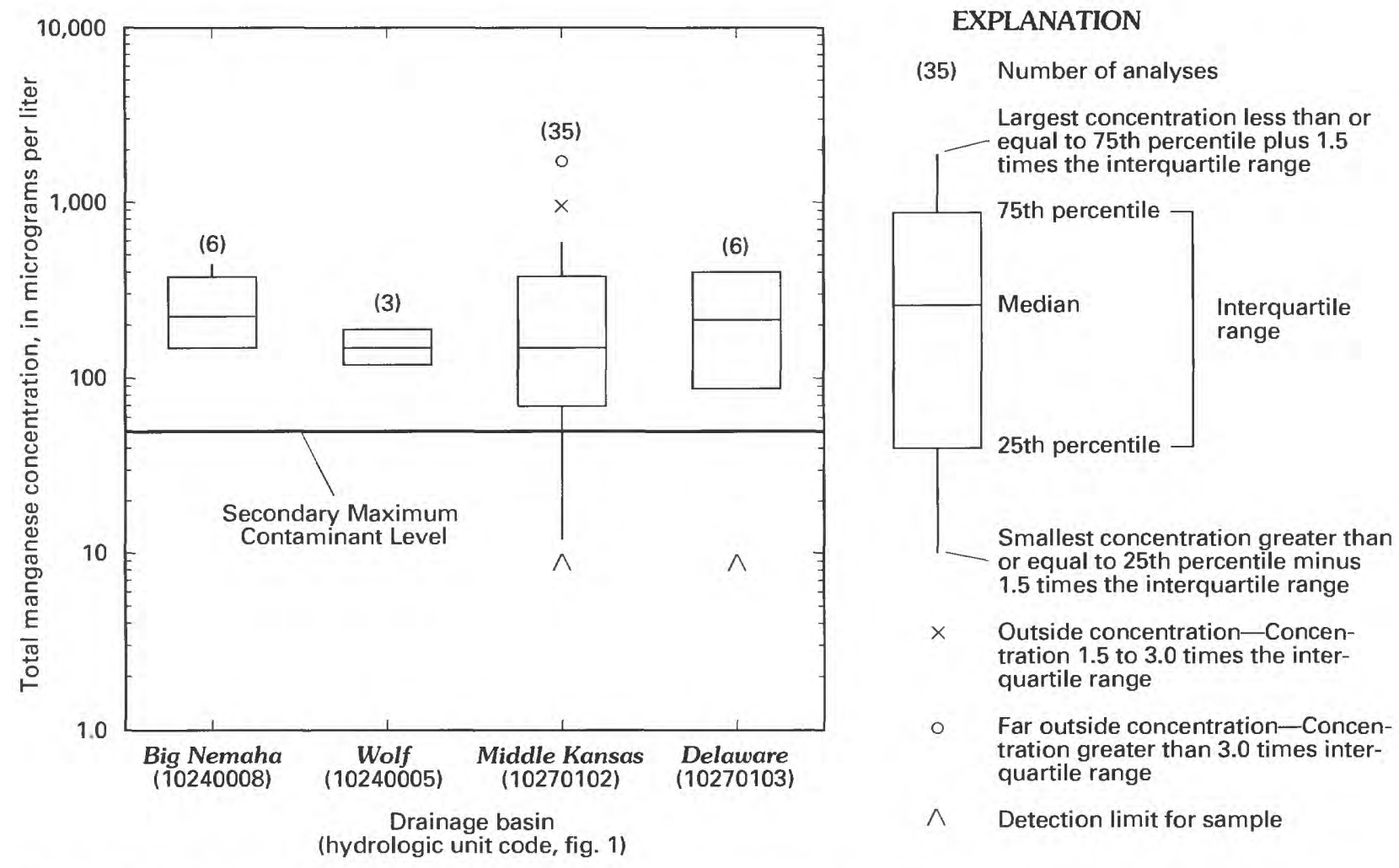

Figure 35. Distribution of total manganese concentrations in surface water of study area. 
digestive tract (U.S. Environmental Protection Agency, 1986). Major point sources for nitrogen entry into water are municipal and industrial wastewater, septic tanks, feedlot discharges, and leachate from waste disposal in dumps or sanitary landfills. Diffuse sources include farm-site fertilizer and animal wastes and lawn fertilizer. An MCL of $10 \mathrm{mg} / \mathrm{L}$ was established by the USEPA (U.S. Environmental Protection Agency, 1986) for nitrite plus nitrate as nitrogen because of possible toxic effects to infants.

Ammonia concentrations are not discussed in this report because ammonia oxidizes to nitrite and nitrate and because it is more volatile than nitrite and nitrate in escaping into the atmosphere.

Nitrite plus nitrate concentrations in surface water from selected surface-water-quality sampling sites in the study area generally are from less than 0.10 to about $2.5 \mathrm{mg} / \mathrm{L}$ (fig. 36). The sampling sites are listed in table 4 and shown in figure 37 . Maximum concentrations generally are less than $5 \mathrm{mg} / \mathrm{L}$. Of the 950 anaylses used to construct figure 36 , one concentration, from the South Branch of Shunganunga Creek at Southwest $37^{\text {th }}$ Street, Topeka, Kansas (site 13), exceeded the 10-mg/L MCL. There were not enough analyses available to evaluate nitrite plus nitrate concentration in ground water.

The USEPA (U.S. Environmental Protection Agency, 1986) SMCL for total phosphate (as phosphorus) is $0.10 \mathrm{mg} / \mathrm{L}$ for aquatic life. Higher concentrations may interfere with coagulation in watertreatment plants. To prevent excessive algal growth, the concentration should not exceed $0.05 \mathrm{mg} / \mathrm{L}$ in any stream at the point where it enters a lake or reservoir nor should it exceed $0.025 \mathrm{mg} / \mathrm{L}$ within the lake or reservoir (U.S. Environmental Protection Agency, 1986).

Phosphorous concentrations in streams of the study area (fig. 38 ) typically are from about 0.020 to about $0.20 \mathrm{mg} / \mathrm{L}$. Most of the available analyses had concentrations that exceed the $0.025-\mathrm{mg} / \mathrm{L}$ SMCL for lakes and reservoirs (U.S. Environmental Protection Agency, 1986). All but three of the median
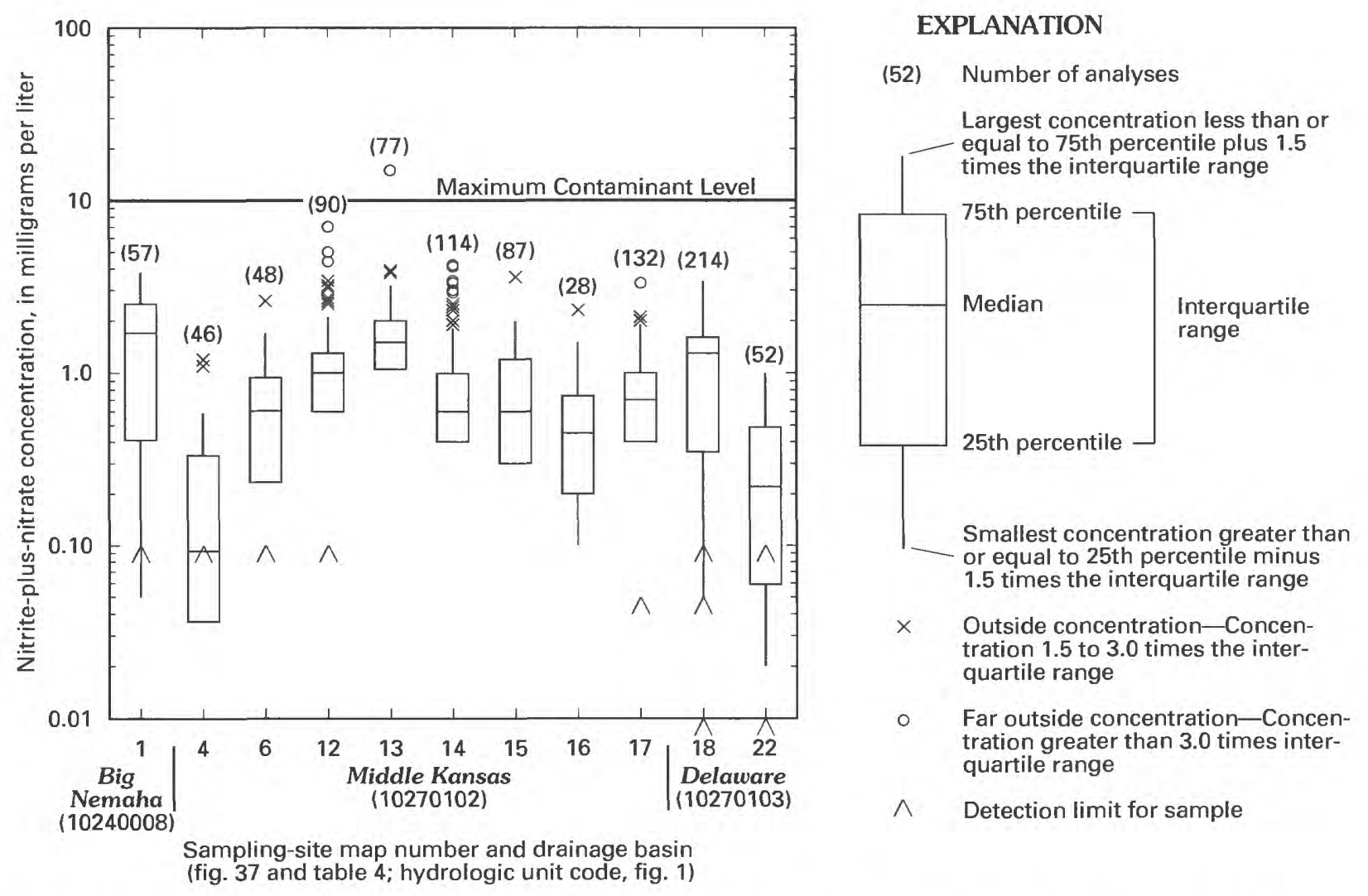

Figure 36. Distribution of nitrite plus nitrate concentrations in surface water from selected surface-water-quality sampling sites in study area. 
Table 4. Selected surface-water-quality sampling sites referred to in this study

\begin{tabular}{|c|c|c|}
\hline $\begin{array}{c}\text { Site } \\
\text { number } \\
\text { (fig. 37) }\end{array}$ & $\begin{array}{l}\text { Site-identification } \\
\text { number }\end{array}$ & Site name \\
\hline & & Big Nemaha River Basin \\
\hline 1 & 06815000 & $\begin{array}{l}\text { Big Nemaha River at Falls City, Nebraska } \\
\text { Middle Kansas River Basin }\end{array}$ \\
\hline 2 & 06887500 & Kansas River at Wamego, Kansas \\
\hline 3 & 06888000 & Vermillion Creek near Wamego, Kansas \\
\hline 4 & 06888500 & Mill Creek near Paxico, Kansas \\
\hline 5 & 06888705 & Kansas River at Willard, Kansas \\
\hline 6 & 06889000 & Kansas River at Topeka, Kansas \\
\hline 7 & 06889200 & Soldier Creek near Delia, Kansas \\
\hline 8 & 06889500 & Soldier Creek near Topeka, Kansas \\
\hline 9 & 390056095420100 & Detention basin outflow, Topeka, Kansas \\
\hline 10 & 390056095420101 & Detention basin east inflow, Topeka, Kansas \\
\hline 11 & 390056095420102 & Detention basin west inflow, Topeka, Kansas \\
\hline 12 & 06889580 & Shunganunga Creek at Southwest 29th Street, Topeka, Kansas \\
\hline 13 & 06889610 & $\begin{array}{l}\text { South Branch Shunganunga Creek at Southwest } 37 \text { th Street, } \\
\text { Topeka, Kansas }\end{array}$ \\
\hline 14 & 06889635 & Butcher Creek at Kansas Place, Topeka, Kansas \\
\hline 15 & 06889640 & Shunganunga Creek at Southwest 15th Street, Topeka, Kansas \\
\hline 16 & 06889690 & Deer Creek at Southeast 6th Street, Topeka, Kansas \\
\hline 17 & 06889700 & $\begin{array}{l}\text { Shunganunga Creek at Rice Road, Topeka, Kansas } \\
\text { Delaware River Basin }\end{array}$ \\
\hline 18 & 06890100 & Delaware River near Muscotah, Kansas \\
\hline 19 & 392823095362800 & Elk Creek near Larkinburg, Kansas \\
\hline 20 & 06890400 & Delaware River near Arrington, Kansas \\
\hline 21 & 06890500 & Delaware River at Valley Falls, Kansas \\
\hline 22 & 06890900 & Delaware River below Perry Dam, Kansas \\
\hline
\end{tabular}

phosphorous concentrations exceed the $0.05-\mathrm{mg} / \mathrm{L}$ SMCL for streams, and one-half of the analyses have phosphorous concentrations that equal or exceed the $0.10-\mathrm{mg} / \mathrm{L}$ SMCL for water treatment. These results suggest there may be a problem with excessive phosphorous at these sites. High phosphorus concentrations are a concern in small impoundments where algal blooms may cause fish kills and taste and odor problems in the water. The sources of the phosphorous probably are fertilizers or geologic materials.

\section{Herbicides}

Several studies relating to herbicide use have been conducted during the past few years. Atrazine is the major herbicide of interest in northeastern Kansas and southeastern Nebraska because it has been used since the late 1950's in the production of corn and grain sorghum. It is the most frequently detected herbicide in surface water (Stamer and Zelt, 1994).

The USEPA (U.S. Environmental Protection Agency, 1994) established an MCL of $3.0 \mu \mathrm{g} / \mathrm{L}$ for 


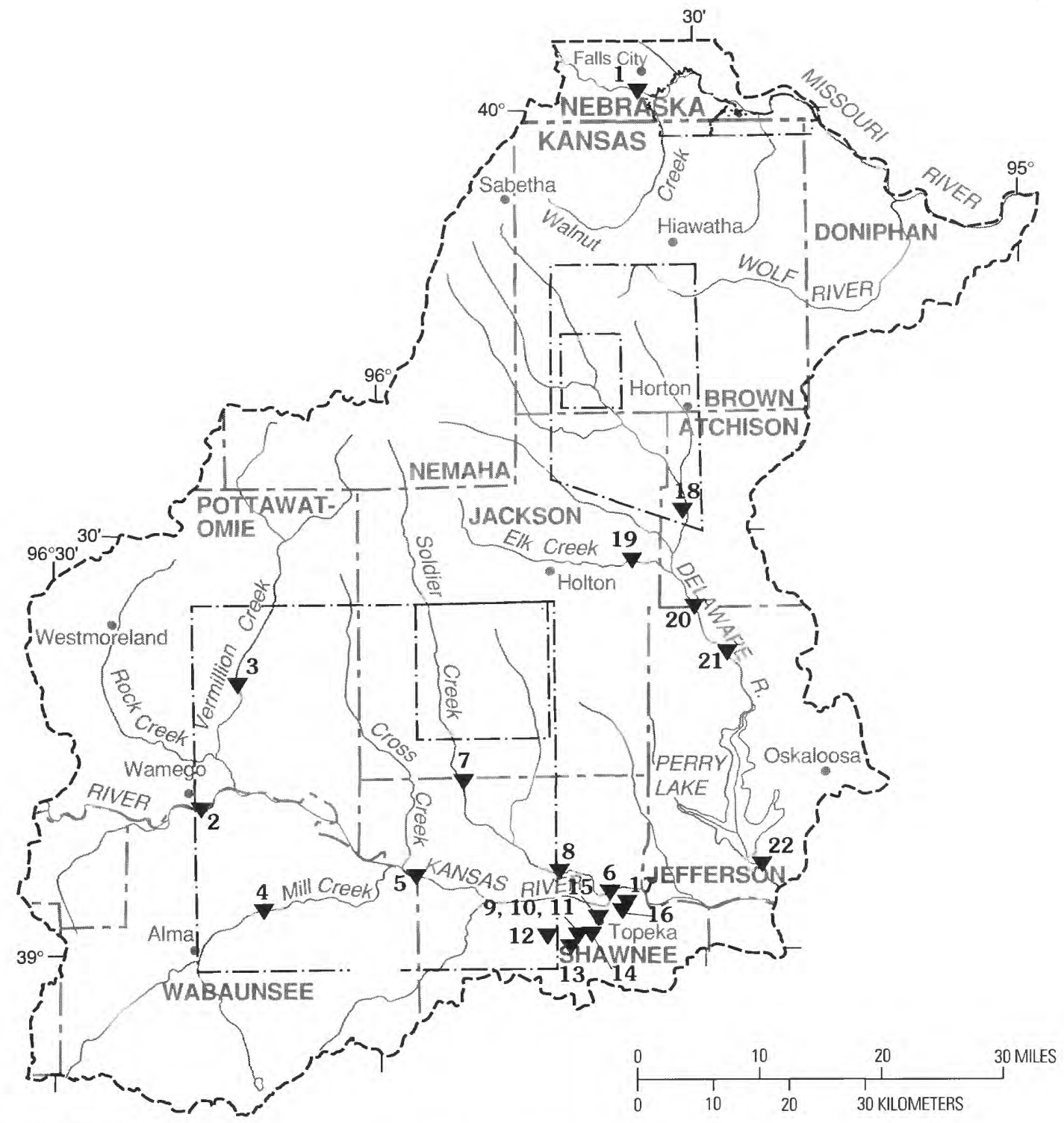

Base from U.S. Geological Survey digital data, 1:100,000, 1972 Lambert Conformal Conic projection Standard paraliels $33^{\circ}$ and $45^{\circ}$

\section{EXPLANATION}

Boundary of study area

Boundary of Indian treaty lands-Boundaries are from U.S. Geological Survey $71 / 2$-minute topographic quadrangles

$\nabla^{7}$ Surface-water-quality sampling site-Number corresponds to that in table 4

Figure 37. Location of selected surface-water-quality sampling sites in study area. 


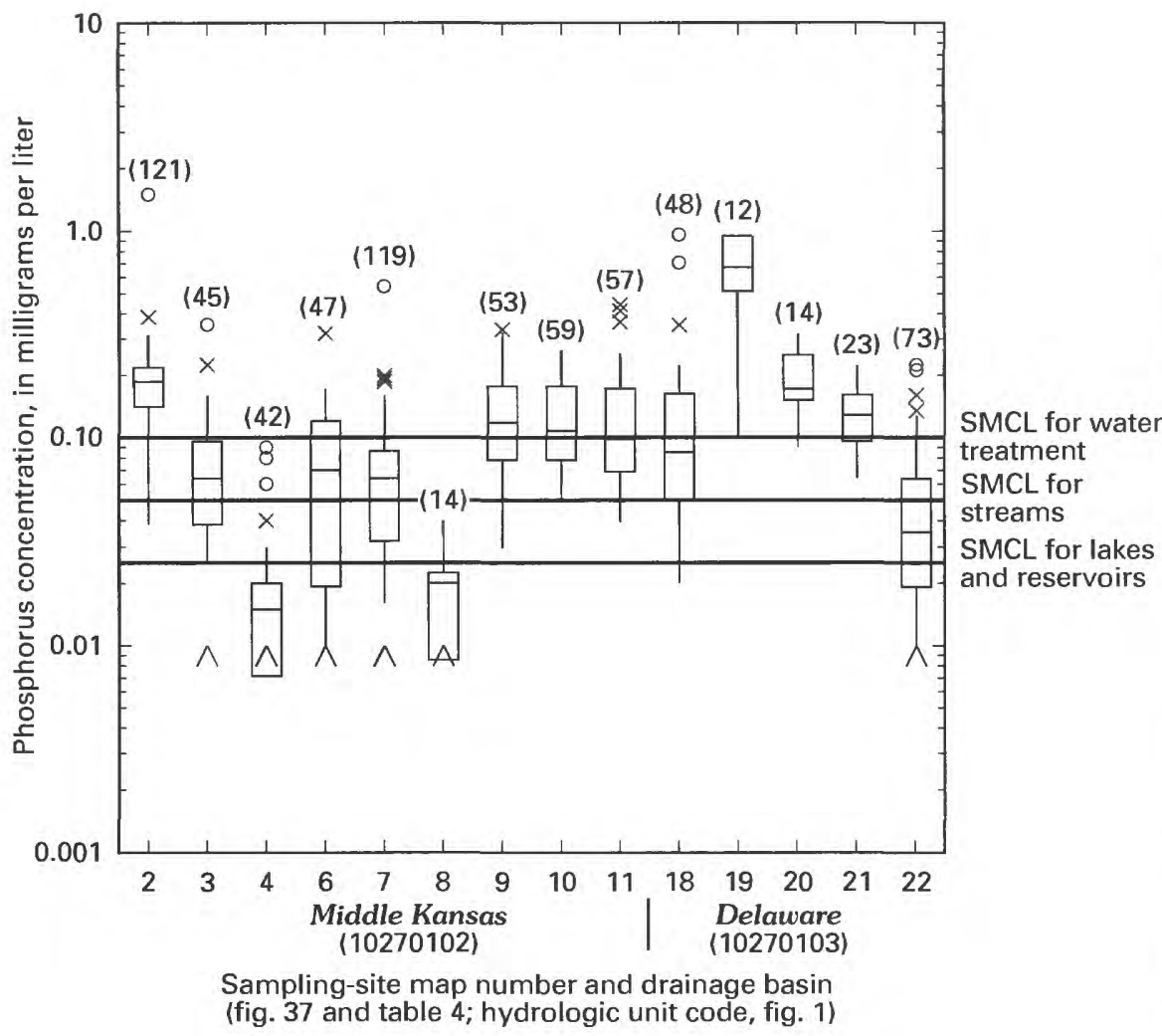

\section{EXPLANATION}

(12) Number of analyses

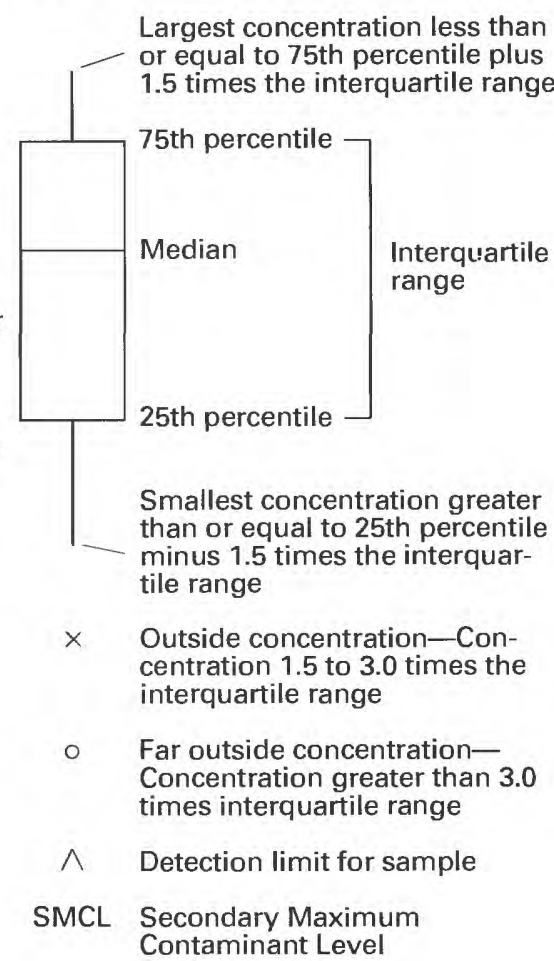

Figure 38. Distribution of phosphorus concentrations in surface water from selected surface-water-quality sampling sites in study area.

atrazine in finished drinking-water supplies. This MCL refers to the annual average of at least four samples for drinking-water supplies, not to a single-sample concentration. Because of concerns that some surface-water supply sources in northeastern Kansas and southeastern Nebraska may exceed the MCL, the Kansas Department of Agriculture initiated a study of potential atrazine contamination in 1990 (Pope, 1995a). The Delaware River Basin was of particular interest because about 85 percent of the basin is used for agriculture, with about 40 percent in row crops such as corn, grain sorghum, soybeans, and wheat (Stamer and others, 1995).

In March 1992, the Kansas Department of Agriculture established the Nation's first inland surfacewater pesticide management area in the Delaware River Basin (Pope, 1995a). A monitoring network consisting of 11 sampling sites was established to: (1) verify or invalidate the perception of a long-term atrazine problem in the basin, (2) determine areas of the basin where educational or outreach activities may be required for atrazine users, and (3) evaluate the effectiveness of land management and agricultural practices.

Water samples for anaiysis of atrazine were collected at the Delaware Basin stream sites and at the outlet of Perry Lake during storm runoff and low-flow periods to compute daily mean concentration (Pope, 1995a). Atrazine concentrations were determined using immunoassay procedures (Baum, 1991), which are not totally specific to atrazine; therefore, other triazine compounds such as ametryn, cyanazine, prometon, prometryn, propazine, and simazine may have been detected and reported as atrazine using this procedure. Results of sampling from July 1992 through December 1994 suggest that daily mean triazine concentrations in streams of the Delaware River Basin commonly exceeded the MCL for atrazine at some times during the months of May, June, and July. Daily mean concentrations at or greater than $30 \mu \mathrm{g} / \mathrm{L}$ were not uncommon. However, daily mean concentrations greater than the MCL were rare at other times of the year, and were generally less than $1.0 \mu \mathrm{g} / \mathrm{L}$ between August and April. The daily mean concentration at the 
Perry Lake outflow was affected largely by the timing and magnitude of the inflow (Pope, 1995a).

In a study of the distribution, transport and relative age of atrazine and selected metabolites in Perry Lake, Fallon (1994) described the effects of precipitation, reservoir-residence time, and herbicide application. Runoff occurring immediately after atrazine application increases atrazine concentrations in the lake. Atrazine concentrations in the lake remain high (greater than $3.0 \mu \mathrm{g} / \mathrm{L}$ ) throughout the year if late- and post-growing season runoff is below average. If lateand post-growing season runoff is above average, atrazine concentrations quickly decrease to less than $2.0 \mu \mathrm{g} / \mathrm{L}$ (Fallon, 1994, p. 84). In small impoundments, atrazine concentrations may reach higher levels than in Perry Lake.

\section{Bacteria}

Fecal coliform and fecal streptococcus bacteria are used as indicators of fecal contamination in water. Wastewater-treatment plants and feedlots are major point sources for contamination. Nonpoint sources include leachate from domestic septic systems, runoff and seepage from livestock areas such as pastures and from wildlife populations.

The USEPA (U.S. Environmental Protection Agency, 1986) established a single-sample maximum allowable density of $576 \mathrm{col} / 100 \mathrm{~mL}$ for Escherichia coli $(E$. coli), a member of the fecal coliform group of bacteria, for infrequently used full-contact recreation. The Kansas Department of Health and Environment established a criterion for fecal coliform of $2,000 \mathrm{col} / 100 \mathrm{~mL}$ for those streams available for all beneficial uses other than full-contact recreation (Fromm and Wilk, 1988). Because the fecal coliform group may contain bacteria other than $E$. coli, the 2,000-col/100 mL criterion, if applied to $E$. coli, may result in more than 2,000 fecal coliform col/100 mL. However, because few streams in the lower Kansas River Basin, which includes a major part of the study area, are classified for full-body contact, Pope (1995b, p. 47-48) used both criteria in a study to evaluate the density of $E$. coli in the lower Kansas River Basin during periods of low flow.

Very few regional data were available to describe bacteria distribution throughout the study area. Two surface-water-quality sampling sites have more than 10 fecal coliform analyses available; one also has fecal streptococcus data available. On the basis of 40 analyses, the Big Nemaha River at Falls City, Nebraska (table 4, sampling site 1), has a typical fecal coliform count of about 2,200 to $8,700 \mathrm{col} / 100 \mathrm{~mL}$, with a median count of 4,100 and a maximum count of $53,000 \mathrm{col} / 100 \mathrm{~mL}$. On the basis of 50 analyses, the typical range for fecal streptococcus at this site is from about 600 to $7,000 \mathrm{col} / 100 \mathrm{~mL}$, with a median count of 1,165 and a maximum count of $500,000 \mathrm{col} / 100 \mathrm{~mL}$. On the basis of 41 analyses, the typical range for fecal coliform bacteria in samples from the Kansas River at Willard, Kansas (table 4, sampling site 5), is from about 80 to $2,300 \mathrm{col} / 100$ $\mathrm{mL}$, with a median of 410 and a maximum of $480,000 \mathrm{col} / 100 \mathrm{~mL}$. Many fecal coliform concentrations at these two sampling sites exceeded both the 576- and 2,000-col/100 mL criteria.

Pope's (1995b) results for the Kansas River Basin between Manhattan, Kansas, and Kansas City, Kansas, show that the median $E$. coli concentration during low-flow periods was $88 \mathrm{col} / 100 \mathrm{~mL}$ (23 sampling sites, 15 of which are in this study area), with a range of less than 1 to $1,000 \mathrm{col} / 100 \mathrm{~mL}$. Only one site, Elk Creek near Larkinburg, Kansas (table 4, site 19), exceeded the $576-\mathrm{col} / 100 \mathrm{~mL}$ criterion.

Available data for the Big Nemaha River at Falls City, Nebraska, and the Kansas River at Willard, Kansas, and the results from Pope (1995b) show substantial variability in fecal bacteria concentrations. During periods of low flow when streamflow is derived primarily from ground water, fecal bacteria concentrations are probably lowest. As streamflow and surface runoff increase, so do fecal bacteria concentrations. The typical range at sampling sites 1 and 4 in the study area exceeded the $576-\mathrm{col} / 100 \mathrm{~mL}$ and $2,000-\mathrm{col} / 100 \mathrm{~mL}$ criteria, which suggests that possible problems with fecal bacteria contamination exist in the study area.

\section{Suspended Sediment}

Few data are available to describe the regional distribution of suspended sediment throughout the study area. Most data are associated with studies related to specific types of sites and streamflow conditions.

As part of the USGS's National Water-Quality Assessment Program, Jordan (1995) summarized suspended-sediment concentrations for about 40 samples at each of four sampling sites (table 4, sampling sites $4,6,18$, and 22) in the study area. Mill Creek near Paxico, Kansas (table 4, site 4), had a median suspended-sediment concentration of $28 \mathrm{mg} / \mathrm{L}$ and a 
$90^{\text {th }}$-percentile concentration (value equals or exceeds 90 percent of samples) of $280 \mathrm{mg} / \mathrm{L}$. The Kansas River at Topeka, Kansas (table 4, sampling site 6), with the highest observed single-sample concentration, had a median concentration of $550 \mathrm{mg} / \mathrm{L}$. Suspended-sediment concentrations from the Kansas River at Topeka are consistent with other sampling sites on the Kansas River in spite of inflow from streams with lower concentrations. Jordan (1995) attributed these higher concentrations to streambed and bank erosion. The Delaware River near Muscotah, Kansas (table 4, sampling site 18) drains an area with a high density of cropland. Sampling sites like this typically have relatively high suspended-sediment concentrations due to runoff from cultivated cropland. The median suspended-sediment concentration for the Delaware River near Muscotah was $34 \mathrm{mg} / \mathrm{L}$, and the $90^{\text {th }}$-percentile concentration was $240 \mathrm{mg} / \mathrm{L}$. These values were lower than expected, probably due to belownormal streamflow at the time of sampling. The Delaware River below Perry Dam (table 4, sampling site 22) had the lowest suspended-sediment concentrations of the four sites. The median concentration was $13 \mathrm{mg} / \mathrm{L}$; the $90^{\text {th }}$-percentile concentration was $58 \mathrm{mg} / \mathrm{L}$. Samples were collected downstream from Perry Lake, a large reservoir, which causes most of the suspended sediment to settle out of the water. In small impoundments, high sediment inflow and subsequent deposition within the reservoir may result in the need for periodic dredging of the impoundment.

In a study of erosion and sediment yield, the U.S. Soil Conservation Service (1992) evaluated sources of suspended sediment in the study area. Seventy to 80 percent of the Big Nemaha River Basin in northeastern Kansas and southeastern Nebraska is cropland. Sheet and rill erosion and ephemeral gullying account for 80 percent of the erosion and 40 to 60 percent of the total sediment yield.

The Wolf River Basin is 70-percent cropland. Sheet and rill erosion accounts for 63 percent of the erosion and 30 percent of the total sediment yield. Classical and ephemeral gullying account for 27 percent of the erosion and 48 percent of the sediment yield. Forty-four percent of the total sediment yield is from cultivated cropland, (U.S. Soil Conservation Service, 1992).

The Delaware River Basin is 57-percent cropland, 37 percent of which is unprotected. Sheet and rill erosion accounts for 74 percent of the total erosion and 42 percent of the total sediment yield. Ephemeral and classical gullying account for 22 percent of the erosion and 47 percent of the total sediment yield. Sheet and rill erosion and ephemeral gullying account for 46 percent of the total sediment yield (U.S. Soil Conservation Service, 1992).

\section{WATER USE}

Water use within each of the four major drainage basins in the study area is illustrated in figure 39 . Annual amounts of surface and ground water used for public supply, rural domestic, stockwatering, irrigation, industrial and mining, and thermoelectric power generation are shown in units of millions of gallons per day (Mgal/d). This information was derived from the most recent comprehensive summary of water use (Solley and others, 1993), which was based on 1990 data. The sources for these data vary among different States and types of use. In Kansas, water use for public supply (that is, cities and rural water districts), irrigation, industry, mining, and thermoelectric power generation is reported to the Kansas Department of Agriculture, Division of Water Resources. In Nebraska, information on water rights and pumping allocations, obtained from the Nebraska Department of Water Resources and the Nebraska Natural Resources Commission, was used to estimate withdrawals for public supply and irrigation use. Water use for livestock, which includes animals on farms as well as in feedlots, was estimated using agricultural statistics for each State and coefficients of water use per head. Water use by rural populations (for the rural domestic category) and for the Kickapoo Reservation (included in public supply) were estimated using census population counts and per-capita use coefficients. Further investigation of actual water demands on reservations is warranted to determine future needs.

A total of $3.13 \mathrm{Mgal} / \mathrm{d}$ was used in the Big Nemaha River Basin during 1990. Of this amount, 74 percent was supplied by ground-water sources. The largest use of water in this basin, 62 percent, was for public supply, all of which was from ground water. Stockwatering represented 19 percent of the total use in the basin and was supplied by both surface- and ground-water sources. Industrial and mining water use in the Big Nemaha River Basin was 12 percent of the total and was supplied entirely by surface-water sources.

A total of $1.29 \mathrm{Mgal} / \mathrm{d}$ was used in the Wolf River Basin during 1990. Of this amount, 71 percent was 
derived from ground-water sources. Water use for public supply represented 39 percent of the total and was derived entirely from ground water. Stockwater was derived from both ground and surface sources and represented 51 percent of the total water use, the largest single use of water in the Wolf River Basin.

A total of $83.01 \mathrm{Mgal} / \mathrm{d}$ was used in the middle Kansas River Basin during 1990 (note the scale change in figure 39). Of this amount, 67 percent was derived from surface-water sources. Public supply was the largest use in this populous basin, and 92 percent of this use was supplied by surface water, primarily from the Kansas River. Stockwatering was $3.19 \mathrm{Mgal} / \mathrm{d}$ and represented almost 4 percent of the total use in the basin. Irrigation use totalled

$15.18 \mathrm{Mgal} / \mathrm{d}$, of which 89 percent was from surface water. Industrial and mining water use was supplied almost entirely from ground water and totalled $6.18 \mathrm{Mgal} / \mathrm{d}$. Thermoelectric power generation is a major use of water in the middle Kansas River Basin, representing 31 percent of the total use. Most of the water used for power generation ( 89 percent) is from surface water and consists of cooling water used at several powerplants and then released back to the river.

A total of $4.37 \mathrm{Mgal} / \mathrm{d}$ was used in the Delaware River Basin during 1990. Of this amount, 55 percent was derived from ground water. About two-thirds of the public-supply water use was supplied from ground-water sources. Stockwatering totalled $1.98 \mathrm{Mgal} / \mathrm{d}$ and was supplied by both surface and ground water.

\section{SUMMARY AND CONCLUSIONS}

Water availability and quality are a major concern to the Iowa Tribe of Kansas and Nebraska, the Kickapoo Tribe of Kansas, the Prairie Band of Potawatomi, and the Sac and Fox Tribe of Missouri. An overview of the surface- and ground-water resources in and near their treaty lands evolved from the tribes' desire to develop their water resources prudently and to have their interests included in the Kansas State Water Plan. The 4,005- $\mathrm{mi}^{2}$ study area is divided into four major drainage basins on the basis of standard hydrologic units and includes the treaty lands for all four tribes.

The only plentiful supplies of surface water are available from the Missouri and Kansas Rivers near the margins of the study area. The Iowa Reservation has direct access to the Missouri River. The Sac and
Fox Reservation borders the Big Nemaha River that is of medium size relative to other streams in the study area. The Kickapoo and Potawatomi Reservations have access to streams having small mean streamflow. The smallest mean flows for 4 consecutive months occur in November through February. The smallest flows for 7 consecutive days in a year occur most often in August, September, or October.

The typical seasonal distribution of streamflows indicates a pattern favorable for the same-year use of small surface-water impoundments for low-flow augmentation; large flows that could be impounded typically occur in the months shortly before augmentation is most needed. However, droughts of 2 or more consecutive years are common and would largely negate the advantage of using small impoundments except for very small water-supply needs.

Construction of new surface-water impoundments within or adjacent to the study area for water supply probably is not practical for streams having drainage areas larger than $300 \mathrm{mi}^{2}$ owing to topography and cost factors related to topography. Draft-storage curves would be useful in making preliminary estimates of potential development of surface-water supplies by impoundment and in comparing the development possibilities of different streams in the study area with drainage areas less than $300 \mathrm{mi}^{2}$.

Availability of ground water in the study area is divided into two categories on the basis of aquifers generally capable of sustaining individual-well pumping rates greater than $300 \mathrm{gal} / \mathrm{min}$ (major aquifers) and those generally capable of sustaining rates of less than $300 \mathrm{gal} / \mathrm{min}$ (minor aquifers). Both the major and minor aquifers are importarit in the study area for different reasons. The major aquifers provide large yields to wells but are limited in areal extent to the Kansas River and Missouri River Valleys. The minor aquifers, although capable of only small yields to wells and sometimes poorer quality water, are available throughtout most of the study area.

There are only two major aquifers that occur in the study area, namely the Kansas River Valley alluvial aquifer and the Missouri River Valley alluvial aquifer. The Kansas River Valley alluvial aquifer is used extensively for irrigation as well as for industrial and municipal purposes, especially near the population centers, but the Missouri River Valley alluvial aquifer is not used extensively.

The Kansas River Valley alluvial aquifer offers great potential for large-capacity wells. Thicknesses of 

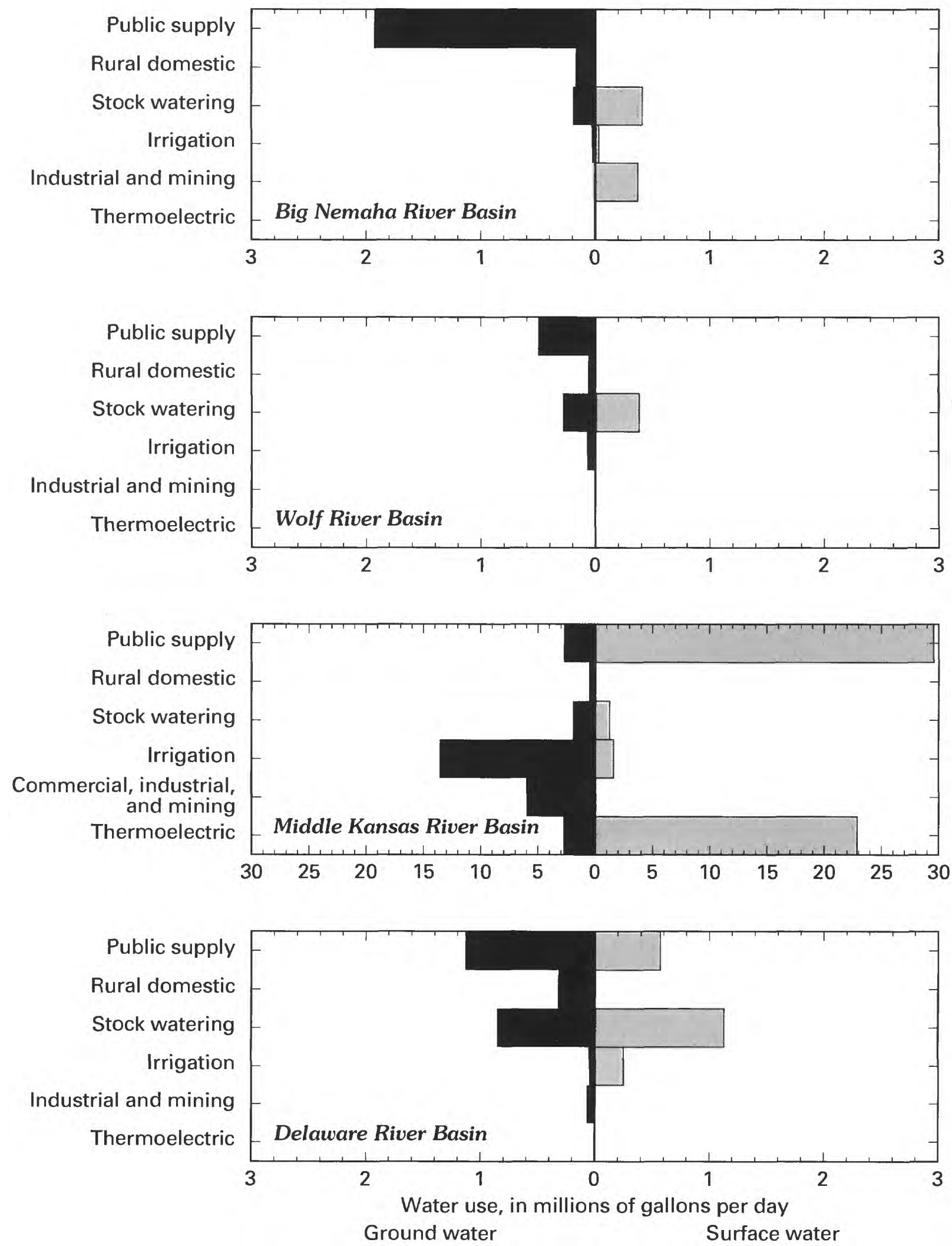

Figure 39. Water use in 1990 by drainage basin (data from Solley and others, 1993). 
the saturated alluvial material range from less than $1 \mathrm{ft}$ near the valley edges to about $70 \mathrm{ft}$ in the deepest part of the buried channel. Reported well yields from the alluvial aquifer in Shawnee County, Kansas, are as large as 2,500 gal $/ \mathrm{min}$. Well yields greater than $1,000 \mathrm{gal} / \mathrm{min}$ are common in areas with more than $40 \mathrm{ft}$ of saturated thickness. Well yields range from 300 to $1,000 \mathrm{gal} / \mathrm{min}$ where saturated thickness is 20 to $40 \mathrm{ft}$, and yields of as much as $500 \mathrm{gal} / \mathrm{min}$ are locally possible even where saturated thickness is less than $20 \mathrm{ft}$. Results of various aquifer tests from wells in the Kansas River Valley alluvial aquifer from Riley County to Wyandotte County, Kansas, showed transmissivities that ranged from 5,300 to $89,600 \mathrm{ft}^{2} / \mathrm{d}$. Storage coefficients ranged from 0.0005 to 0.20 .

The Missouri River Valley alluvial aquifer also offers one of the greatest potentials in the study area for large-capacity wells because of the relatively large hydraulic conductivity of the sediments, abundant precipitation available for recharge, and the possibility of induced recharge from the Missouri River if wells are located near the river. Thicknesses of the sediments range from zero at the valley walls to as much as $120 \mathrm{ft}$ in the deepest part of the buried channel. Aquifer tests for the Missouri River Valley alluvial aquifer in Doniphan, Atchison, and Leavenworth Counties, Kansas, had transmissivities that ranged from 26,800 to $80,400 \mathrm{ft}^{2} / \mathrm{d}$ and storage coefficients that ranged from 0.0004 to 0.001 . Reported well yields from the alluvial aquifer in Doniphan County ranged from 150 to $250 \mathrm{gal} / \mathrm{min}$, but as much as $3,000 \mathrm{gal} / \mathrm{min}$ may be obtained from coarse-grained sediments in the alluvium. Water-level maps were published for the Missouri River Valley alluvial aquifer for Doniphan County, Kansas, for 1967 and for the Missouri side between Kansas City, Missouri, and the Iowa border for January 1968.

Minor aquifers that occur throughout the study area include small stream-valley alluvial aquifers, sand and gravel aquifers buried in glacial deposits, buried bedrock-valley aquifers, and bedrock aquifers.

Although most of the small stream valleys in the study area generally contain clayey or silty alluvium, the alluvial deposits generally have some coarser material near the bottom of the valley. Data are not available for most of the small stream-valley alluvial aquifers; however transmissivities determined from aquifer tests for wells 45 to $64 \mathrm{ft}$ deep in the Delaware River alluvial aquifer were mainly from 670 to
$1,070 \mathrm{ft}^{2} / \mathrm{d}$, with storage coefficients of 0.0004 ; the largest transmissivity value was $3,430 \mathrm{ft}^{2} / \mathrm{d}$.

Within the thick, mostly fine-grained glacial sediments there are isolated deposits of buried sand and gravel of various but usually limited sizes capable of supplying sources of water for individual house, farm, or stock wells. Initial well yields may be large, but quickly decrease with sustained pumping as withdrawals exceed the very small recharge amounts coming through the surrounding small-hydraulic-conductivity deposits. Test-hole drilling is the most reliable method of locating these buried aquifers; generally the thicker the glacial deposits, the better the chance of finding a reliable ground-water source.

The buried bedrock valleys generally are filled with clayey glacial deposits, but most valleys contain some sand and gravel. The largest buried valley, which trends eastward across Nemaha, Jackson, and Atchison Counties, Kansas, may be as much as 3 mi wide, $400 \mathrm{ft}$ deep, and as much as $75 \mathrm{mi}$ long; tributary valleys join the main stem of the buried valley to form a typical dendritic drainage pattern. Wells completed in the coarsest sand and gravel may yield as much as $900 \mathrm{gal} / \mathrm{min}$, but less than $500 \mathrm{gal} / \mathrm{min}$ is more common. Aquifer tests for wells completed in the major buried valley extending from Nemaha County to Atchison County, Kansas, had tranmissivities of 335 to $3,430 \mathrm{ft}^{2} / \mathrm{d}$ and storage coefficients of 0.00002 to 0.002 .

Where the alluvial and glacial deposits are thin or absent, the underlying bedrock is the only other source of water to wells. The surface of the Precambrian crystalline basement rock surface essentially represents the base of all water-bearing rocks in the area. Above this surface, deep saline water-bearing bedrock aquifers are mostly unused, except for disposal of oilfield brines; shallow water-bearing bedrock aquifers may contain either saline or freshwater and locally are used for minor water supplies where the water is fresh.

Calcium, magnesium, sodium, bicarbonate, and chloride are the major dissolved constituents in both surface and ground water in the study area. Sodium concentrations exceeding the USEPA SMCL of $20 \mathrm{mg} / \mathrm{L}$ occur in all four major drainage basins. Water from the middle Kansas and Delaware Basins exceed the SMCL most often. Chloride concentrations do not generally exceed the USEPA SMCL of $250 \mathrm{mg} / \mathrm{L}$.

Sulfate concentrations in surface water generally are not a problem; water from only three surfacewater-quality sampling sites exceeded the 
USEPA SMCL of $250 \mathrm{mg} / \mathrm{L}$. There may be a problem with sulfate concentrations in some wells in the Big Nemaha, middle Kansas, and Delaware Basins. Potential sources include dissolution of sulfate minerals such as gypsum and pyrite.

Total iron and manganese concentrations throughout the study area tend to be high. The typical range for total iron in surface water of about 300 to $5,000 \mu \mathrm{g} / \mathrm{L}$ exceeds the USEPA SMCL of $300 \mu \mathrm{g} / \mathrm{L}$. Reducing conditions in ground water where there is no dissolved oxygen allow iron concentrations to reach as high as $60,000 \mu \mathrm{g} / \mathrm{L}$. Available analyses for manganese typically exceeded the SMCL of $50 \mu \mathrm{g} / \mathrm{L}$.

Nitrite plus nitrate concentrations in surface water from the study area typically range from less than 0.10 to about $2.5 \mathrm{mg} / \mathrm{L}$. Maximum concentrations generally are less than $5.0 \mathrm{mg} / \mathrm{L}$, one-half of the $10-\mathrm{mg} / \mathrm{L}$ MCL. The typical range of phosphorus concentrations in the study area is from about 0.02 to $0.20 \mathrm{mg} / \mathrm{L}$. Most analyses exceeded the $0.025-\mathrm{mg} / \mathrm{L}$ SMCL for lakes and reservoirs. Median concentrations generally exceed the $0.05-\mathrm{mg} / \mathrm{L}$ SMCL for streams. High phosphorus concentrations may cause algal blooms and taste and odor problems in the water.

Potential water-quality problems in the study area result from agricultural practices. Atrazine concentrations in the Delaware River Basin, primarily from post-application runoff, commonly exceed the MCL (3.0 $\mu \mathrm{g} / \mathrm{L})$ during the months of May, June, and July. Daily mean concentrations may exceed $30 \mu \mathrm{g} / \mathrm{L}$. Most of the erosion and about one-half of the total sediment yield in parts of the study area may be derived from sheet and rill erosion and gullying on cultivated cropland.

A total of $3.13 \mathrm{Mgal} / \mathrm{d}$ of water was used in the Big Nemaha River Basin during 1990, 74 percent supplied by ground-water sources. In the Wolf River Basin, 1.29 Mgal/d were used, 71 percent derived from ground water. The middle Kansas River Basin had the highest water use, $83.01 \mathrm{Mgal} / \mathrm{d}, 67$ percent derived from surface water. Thermoelectric power generation accounted for 31 percent of the total water use in the middle Kansas River Basin; water is used at several powerplants and then released back to the river. A total of $4.37 \mathrm{Mgal} / \mathrm{d}$ was used in the Delaware River Basin, 55 percent derived from ground water.

\section{REFERENCES}

Baum, E.J., 1991, The advantages of field-portable enzyme immunoassays: Environmental Lab, On-Site News, December/January 1991/1992, unnumbered pages.

Bayne, C.K., 1973, Geohydrology of Doniphan County, northeastern Kansas: U.S. Geological Survey Hydrologic Investigations Atlas HA-462, 1 sheet, scale $1: 62,500$.

Bayne, C.K., and Schoewe, W.H., 1967, Geology and ground-water resources of Brown County, Kansas: Kansas Geological Survey Bulletin 186, 68 p.

Beck, H.V., 1959, Geology and ground-water resources of Kansas River Valley between Wamego and Topeka, Kansas vicinity: Kansas Geological Survey Bulletin 135, 88 p.

Bidwell, O.W., Dunmire, R.G., and Templin, E.H., 1960 , Soil survey of Geary County, Kansas: U.S. Department of Agriculture, Soil Conservation Service, 35 p.

Blaine, M.R., 1979, The Ioway Indians: Norman, University of Oklahoma Press, 364 p.

Brewer, L.D., Trombley, T.J., and Pomes, M.L., 1994, Water resources on and near Indian lands in northeastern Kansas and southeastern Nebraska-Hydrologic data through 1990: U.S. Geological Survey Open-File Report 94-35, 424 p.

Campbell, H.V., Dickey, H.P., and Rowland, H.T., 1979, Soil survey of Jackson County, Kansas: U.S. Department of Agriculture, Soil Conservation Service, 86 p.

Carswell, W.J., Jr., 1982, Storage requirements to sustain gross reservoir outflow from small basins in Kansas: Kansas Water Office Technical Report No. 16, 40 p.

Cohen, F.S., 1982, Handbook of Federal Indian law: Charlottesville, Virginia, Michie Bobbs-Merill, 912 p.

Cole, V.B., 1976. Configuration of the top of Precambrian rocks in Kansas: Kansas Geological Survey Map Series M-7, 1 sheet, scale 1:500,000.

Davis, S.N., and Carlson, W.A., 1952, Geology and groundwater resources of the Kansas River Valley between Lawrence and Topeka, Kansas: Kansas Geological Survey Bulletin 96, part 5, p. 201-276.

Denne, J.E., Steeples, D.W., Sophocleous, M.A., Severini, A.F., and Lucas, J.R., 1982, An integrated approach for locating glacial buried valleys: Kansas Geological Survey Groundwater Series 5, 22 p.

Dickey, H.P., Zimmerman, J.L., and Rowland, H.T., 1977, Soil survey of Jefferson County, Kansas: U.S. Department of Agriculture, Soil Conservation Service, 67 p.

Dreeszen, V.H., and Burchett, R.R., 1971, Buried valleys in the lower part of the Missouri River Basin, in Pleistocene stratigraphy of Missouri River Valley along the Kansas-Missouri border, Guidebook, 20th annual meeting of the Midwest Friends of the Pleistocene: Kansas Geological Survey Special Distribution Publication 53, p. 21-25. 
Dufford, A.E., 1958, Quarternary geology and groundwater resources of Kansas River Valley between Bonner Springs and Lawrence, Kansas: Kansas Geological Survey Bulletin 130, part 1, $96 \mathrm{p}$.

Dugan, J.T., 1984, Hydrologic characteristics of Nebraska soils: U.S. Geological Survey Water-Supply Paper 2222, 19 p.

1986, Hydrologic characteristics of soils in parts of Arkansas, Colorado, Kansas, Missouri, Nebraska, New Mexico, Oklahoma, South Dakota, and Texas: U.S. Geological Survey Hydrologic Investigations Atlas HA-678, 1 sheet, scale 1:1,500,000.

Eagleman, J.R., 1975, Visualization of climate: Lawrence, University of Kansas Printing Service, 142 p.

Eikleberry, R.W., and Templin, E.H., 1960, Soil survey of Brown County, Kansas: U.S. Department of Agriculture, Soil Conservation Service, $32 \mathrm{p}$.

Emery, P.A., 1964, Geology and ground-water resources of Richardson County, Nebraska: U.S. Geological Survey Water-Supply Paper 1779-W, 29 p.

Emmett, L.F., and Jeffery, H.G., 1969, Reconnaissance of the ground-water resources of the Missouri River alluvium between Kansas City, Missouri and the Iowa border: U.S. Geological Survey Hydrologic Investigations Atlas HA-336, 1 sheet, scale 1:125,000.

Fader, S.W., 1974, Ground water in the Kansas River Valley, Junction City to Kansas City, Kansas: Kansas Geological Survey Bulletin 206, part 2, 12 p.

Fallon, J.D., 1994, Determining the three dimensional distribution, transport, and relative age of atrazine and selected metabolites in Perry Lake, Kansas: Lawrence, University of Kansas master's thesis, 191 p.

Fenneman, N.M., 1938, Physiography of eastern United States: New York, McGraw-Hill, Inc., p. 588-605.

Fenneman, N.M., and Johnson, D.G., 1946, Physical divisions of the United States [map]: U.S. Geological Survey, 1 sheet, scale 1:7,000,000.

Frey, J.C., 1941, Reconnaissance of ground-water resources in Atchison County, Kansas: Kansas Geological Survey Bulletin 38, part 9, p. 237-260.

Fromm, Carla, and Wilk, Sally, eds., 1988, Kansas water quality assessment 1986-1987: Topeka, Kansas Department of Health and Environment 305 (b) Report, 144 p.

Furness, L.W., 1962, Storage requirements to sustain gross reservoir outflow: Kansas Water Resources Board Technical Report No. 4, 177 p.

Hagan, W.T., 1958, The Sac and Fox Indians: Norman, University of Oklahoma Press, 287 p.

Hedman, E.R., and Jorgensen, D.G., 1990, Surface- and ground-water interaction and hydrologic budget of the Missouri River Valley aquifer between Yankton, South Dakota, and St. Louis, Missouri: U.S. Geological Survey Hydrologic Investigations Atlas HA-721, 2 sheets, scale $1: 1,500,000$.
Helsel, D.R., and Hirsch, R.M., 1992, Statistical methods in water resources: New York, Elsevier Science Publ. Co., Inc., 522 p.

Hem, J.D., 1985, Study and interpretation of the chemical characteristics of natural water (3d ed): U.S. Geological Survey Water-Supply Paper 2254, 263 p.

Herring, J.B., 1988, Kenekuk, the Kickapoo prophet: Lawrence, University of Kansas Press, 176 p.

Holmes, Arthur, 1959, A revised geological time-scale: Transactions of Edinburgh Geological Society, v. 17, pt. 3, p. 183-216.

Horsch, M.L., Kutnink, P.R., Gier, D.A., Tricks, B.D., and Wehmueller, W.A., 1987, Soil survey of Pottawatomie County, Kansas: U.S. Department of Agriculture, Soil Conservation Service, 153 p.

Jantz, D.R., Harner, R.F., Rowland, H.T., and Gier, D.A., 1975, Soil survey of Riley County and part of Geary County, Kansas: U.S. Department of Agriculture, Soil Conservation Service, 71 p.

Johnson, W.D., Jr., Adkison, W.L., and Wagner, H.C., 1967, Geology of Shawnee County, Kansas: U.S. Geological Survey Bulletin 215, 254 p.

Jordan, P.R., 1983, Magnitude and frequency of low flows of unregulated streams in Kansas, and estimation of flow-duration curves for ungaged sites: Kansas Water Office Technical Report No. 17, 55 p.

1986, Kansas surface-water resources, in National water summary 1985 - Hydrologic events and surfacewater resources: U.S. Geological Survey Water-Supply Paper 2300, p. 237-244.

1995, Suspended sediment, in Helgesen, J.O., ed., Surface-water-quality assessment of the lower Kansas River Basin, Kansas and Nebraska-Results of investigations, 1987-90: U.S. Geological Survey Open-File Report 94-365, p. 45-55.

Jorgensen, D.G., Helgesen, J.O., and Imes, J.L., 1993, Regional aquifers in Kansas, Nebraska, and parts of Arkansas, Colorado, Missouri, New Mexico, Oklahoma, South Dakota, Texas, and Wyoming-Geohydrologic framework: U.S. Geological Survey Professional Paper 1414-B, 72 p.

Kansas Geological Survey, 1964, Geologic map of Kansas: Kansas Geological Survey Map Series M-1, scale 1:500,000, 1 sheet.

Kappler, C.J., 1972, Indian treaties 1778-1883: New York, Interland Publ. Co., 1099 p.

Kutnink, P.R., Gier, D.A., Haberman, R.L., and Jantz, D.R., 1982, Soil survey of Nemaha County, Kansas: U.S. Department of Agriculture, Soil Conservation Service, $89 \mathrm{p}$. 
Matalas, N.C., 1990, What statistics can tell us, in Waggoner, P.E., ed., Climate change and U.S. water resources, in Report of the American Association for the Advancement of Science Panel on Climatic Variability, Climate Change and the Planning and Management of U.S. Water Resources: New York, John Wiley \& Sons, p. 139-149.

Mathey, S.B., 1990, Ground-water site inventory system, v. 2, chap. 4, in National water information system user's manual: U.S. Geological Survey Open-File Report 89-587, 288 p.

Merriam, D.L., 1963, Geologic history of Kansas: Kansas Geological Survey Bulletin 162, 317 p.

Missouri River Basin Commission, 1976, State and Federal water and related land resource programs: Omaha, Nebraska, Missouri River Basin Commission, 385 p.

Mitchell, G.E., 1994, A short history of the Prairie Band Potawatomi, 1634-1929: Mayetta, Kansas, 35 p.

Murray, W.G., 1965, Kickapoo tracts in Missouri and Kansas, 1883: New York, Clearwater Publ. Co., Inc., $126 \mathrm{p}$.

National Oceanic and Atmospheric Administration, 199294: Climatologic data-Kansas: Asheville, N.C., National Climatic Center [published monthly].

Nielson, G.R., 1975, The Kickapoo people: Phoenix, Arizona, Indian Tribal Series, 104 p.

O’Connor, H.G., 1960, Geology and ground-water resources of Douglas County, Kansas: Kansas Geological Survey Bulletin 148, 200 p.

Pope, L.M., 1995a, Atrazine in surface water and relation to hydrologic conditions within the Delaware River Basin Pesticide Management Area, northeast Kansas, July 1992 through December 1994: U.S. Geological Survey Fact Sheet FS-196-95, 4 p.

1995b, Dissolved oxygen and fecal-indicator bacteria, in Helgesen, J.O., ed., Surface-water-quality assessment of the lower Kansas River Basin, Kansas and Nebraska-Results of investigations, 1987-90: U.S. Geological Survey Open-File Report 94-365, p. 77-85.

Pope, L.M., and Bevans, H.E., 1986, Relation of urban land use and dry weather, storm, and snowmelt flow characteristics to stream-water quality, Shunganunga Creek Basin, Topeka, Kansas: U.S. Geological Survey WaterSupply Paper 2283, 39 p.

Reed, T.B., and Burnett, R.D., 1985, Compilation and analyses of aquifer performance tests in eastern Kansas: U.S. Geological Survey Open-File Report 85-200, $125 \mathrm{p}$.

Ross, J.A., compiler, 1991, Geologic map of Kansas: Kansas Geologic Map Series M-23, 1 sheet, scale 1:500,000 (digital version from Data Access and Support Center, Lawrence, Kansas, 1992).
Sallee, K.H., 1980, Soil survey of Doniphan County, Kansas: U.S. Department of Agriculture, Soil Conservation Service, $86 \mathrm{p}$.

Sallee, K.H., and Watts, C.E., 1984, Soil survey of Atchison County, Kansas: U.S. Department of Agriculture, Soil Conservation Service, 105 p.

Schoewe, W.H., 1949, The geography of Kansas: Transactions of Kansas Academy of Science, v. 52, no. 3, p. 261-333.

Seaber, P.R., Kapinos, F.P., and Knapp, G.L., 1987, Hydrologic unit maps: U.S. Geological Survey Water-Supply Paper 2294, $63 \mathrm{p}$.

Solley, W.B., Pierce, R.R., and Perlman, H.A., 1993, Estimated use of water in the United States in 1990: U.S. Geological Survey Circular 1081, 76 p.

Stamer, J.K., Gunderson, K.D., and Ryan, B.J., 1995, Atrazine concentrations in the Delaware River, Kansas: U.S. Geological Survey Fact Sheet FS-001-95, 2 p.

Stamer, J.K., and Zelt, R.B., 1994, Organo-nitrogen herbicides in the lower Kansas River Basin: Journal of American Water Works Association, January 1994, p. 93-104.

Thornthwaite, C.W., 1941, Atlas of climatic types in the United States, 1900-39: U.S. Department of Agriculture Miscellaneous Publication 421, 55 p.

Trombley, T.J., and Kenny, J.F., 1992, Water resources on and near Indian lands in northeastern Kansas and southeastern Nebraska-Study description: U.S. Geological Survey Open-File Report 91-468, 19 p.

U.S. Department of Commerce, 1968, Climatic atlas of the United States: p. 63.

U.S. Environmental Protection Agency, 1986, Quality criteria for water: U.S. Environmental Protection Agency, EPA 440/5-86-001, 479 p.

1994, Drinking water regulations and health advisories: Washington, D.C., U.S. Environmental Protection Agency, unnumbered pages.

U.S. Soil Conservation Service, 1992, Northeast Kansas erosion and sediment yield report: Washington, D.C., U.S. Department of Agriculture, $60 \mathrm{p}$.

Van Doren-Hazard-Stallings, 1981, Water resources investigation for the Kickapoo Tribe of Kansas: Topeka, Kansas, $35 \mathrm{p}$.

Waldman, C., 1985, Atlas of the North American Indian: New York, Facts on File Publications, 276 p.

Walters, K.L., 1953, Geology and ground-water resources of Jackson County, Kansas: Kansas Geological Survey Bulletin 101, $91 \mathrm{p}$.

Ward, J.R., 1973, Geohydrology of Atchison County, northeastern Kansas: U.S. Geological Survey Hydrologic Investigations Atlas HA-467. 1 sheet, scale 1:62,500. -1974, Geohydrology of Nemaha County, northeastern Kansas: Kansas Geological Survey Ground Water Series 2, 19 p. 
Winslow, J.D., 1972, Geohydrology of Jefferson County, Kansas: Kansas Geological Survey Bulletin 202, part 4, $20 \mathrm{p}$.

Winslow, J.D., and Nuzman, C.E., 1966, Electronic simulation of ground-water hydrology in the Kansas River Valley near Topeka, Kansas: Kansas Geological Survey Special Distribution Publication 29, 24 p.

Wolf, R.J., Hansen, C.V., McGovern, H.E., and Spinazola, J.M., 1990, Geohydrologic systems in Kansas with emphasis on systems in upper Cambrian through lower
Cretaceous rocks: U.S. Geological Survey Hydrologic Investigations Atlas $\mathrm{HA}-722-\mathrm{A}, 2$ sheets, scale $1: 1,500,000$ and $1: 2,000,000$.

Wolf, R.J., and Helgesen, J.O., 1993, Ground- and surfacewater interaction between the Kansas River and associated alluvial aquifer, northeastern Kansas: U.S. Geological Survey Water-Resources Investigations Report 92-4137, 49 p.

Zeller, D.E., ed., 1968, The stratigraphic succession in Kansas: Kansas Geological Survey Bulletin 189, 81 p. 